Florida International University FIU Digital Commons

\title{
The Response to an ESL Population Boom in the Beaufort County, South Carolina School System: A Case Study
}

Amanda G. de Varona

Florida International University, mandydevarona@hotmail.com

DOI: $10.25148 /$ etd.FI14071151

Follow this and additional works at: https://digitalcommons.fiu.edu/etd

Part of the Bilingual, Multilingual, and Multicultural Education Commons, Curriculum and Instruction Commons, Educational Leadership Commons, Educational Methods Commons, Elementary Education and Teaching Commons, Junior High, Intermediate, Middle School Education and Teaching Commons, and the Other Teacher Education and Professional Development Commons

\section{Recommended Citation}

de Varona, Amanda G., "The Response to an ESL Population Boom in the Beaufort County, South Carolina School System: A Case Study" (2014). FIU Electronic Theses and Dissertations. 1568.

https://digitalcommons.fiu.edu/etd/1568 


\section{FLORIDA INTERNATIONAL UNIVERSITY}

Miami, Florida

THE RESPONSE TO AN ESL POPULATION BOOM IN THE BEAUFORT COUNTY, SOUTH CAROLINA SCHOOL SYSTEM: A CASE STUDY

A dissertation submitted in partial fulfillment of the

requirements for the degree of

DOCTOR OF EDUCATION

in

CURRICULUM and INSTRUCTION

by

Amanda Gail de Varona 
To: Dean Delia C. Garcia

College of Education

This dissertation, written by Amanda Gail de Varona, and entitled The Response to an ESL Population Boom in the Beaufort County, South Carolina School System: A Case Study, having been approved in respect to style and intellectual content, is referred to you for judgment.

We have read this dissertation and recommend that it be approved.

Santiago Juan-Navarro, Committee Member

Aixa Perez-Prado, Committee Member

Teresa Lucas, Committee Member

Eric Dwyer, Major Professor

Date of Defense: June 16, 2014

The dissertation of Amanda Gail de Varona is approved.

Dean Delia C. Garcia

College of Education

Dean Lakshmi N. Reddi

University Graduate School

Florida International University, 2014 


\section{DEDICATION}

This is dedicated to five most important people in my life: my parents, my children, and my husband. My parents, Mary and James McCready, have always supported me and pushed me to go further with my education. Without their constant love, support, sacrifice, and encouragement, I would not be where I am today. Secondly, I dedicate this to my daughters Becky and Olivia. They are the reason I live and do everything that I do. I hope this will inspire them to follow their dreams until the end and to know that nothing they want to accomplish is impossible. Finally, I want to thank my husband, Dreiver. He has been my cheerleader and encouraged me to keep going and to keep fighting. He has believed in me all the times I didn’t believe in myself and wanted to give up. I love you all more than know and want to thank you for supporting me. Without you, I wouldn't be me. 


\section{ACKNOWLEDGMENTS}

I would like to express my gratitude to my all of my committee members: Dr. Aixa Perez-Prado, Dr. Teresa Lucas, and Dr. Santiago Juan-Navarro. I have to extend a special thanks to my committee chair, Dr. Eric Dwyer, for his patience in reading so many drafts and answering so many questions. The four of you will always be remembered fondly for helping me to accomplish a dream.

Secondly, I would be remiss not thank Sarah Owen and the teachers of Beaufort County who participated in this study. I sincerely appreciate your cooperation and candor during this process. Thank you for the wonderful work that you have done and that you do with the ESOL students of Beaufort County. 
ABSTRACT OF THE DISSERTATION

THE RESPONSE TO AN ESL POPULATION BOOM IN THE BEAUFORT COUNTY, SOUTH CAROLINA SCHOOL SYSTEM: A CASE STUDY

by

Amanda Gail de Varona

Florida International University, 2014

Miami, Florida

Professor Eric Dwyer, Major Professor

The purpose of this case study was to examine the why the English language learners (ELLs) in the Beaufort County, South Carolina school system have been so successful. This school system has recently experienced a boom in its ESL student population, and this population has performed very well on standardized tests. This study used critical theory as its theoretical framework and examined why the students have been successful rather than marginalized in Beaufort County schools. This phenomenon was investigated using semi-structured interviews with the ESOL Coordinator for Beaufort County, 4 ESL-lead teachers, and 6 mainstream teachers.

Data were collected using semi-structured interviews with Sarah Owen, the Beaufort County ESOL, Gifted and Talented, and World Languages coordinator. Based on the results of her interview, 4 themes emerged that were used for the semi-structured interviews with ESOL and mainstream teachers. The interviews centered on the themes of ESL policy, ESL leadership, and teacher training. The ESL and mainstream teacher interviews also revealed several subthemes that included teacher attitude, why Beaufort County has been successful with the ELLs, and the teachers' recommendations for other 
schools systems trying to successfully accommodate a large ESL student population in mainstream classrooms.

The findings from the teachers' interviews revealed that additional training for the teachers without ESL experience helped them become comfortable instructing ELLs. This training should be conducted by the ESOL teachers for those without ESOL certification or endorsement. As the teachers had more training, they had better attitudes about teaching ESOL students in their classes. Finally, those who utilized the additional ESOL training and ESOL accommodations saw better student achievement in their classes.

Based on the finding of this study, the researcher proposed a model for other school systems to follow in order to replicate the success of Beaufort County’s ELLs. The implications of this study focus on other schools systems and why ELLs are not obtaining the same level of success as those in Beaufort County’s schools. Finally, recommendations for further research are provided. 


\section{TABLE OF CONTENTS}

CHAPTER

PAGE

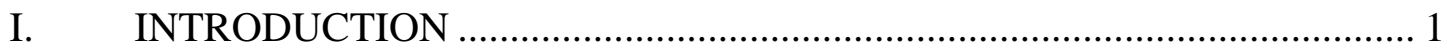

Background ............................................................................................ 1

Statement of Research Problem ........................................................................ 13

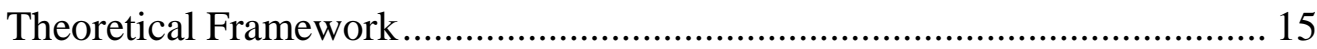

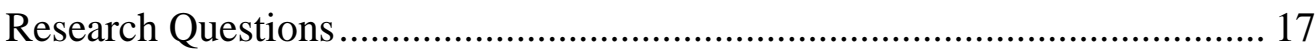

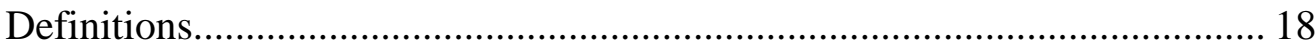

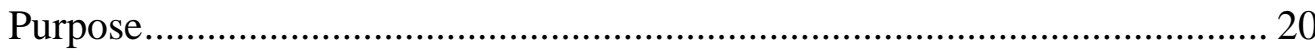

Significance to Theory and Practice ............................................................ 21

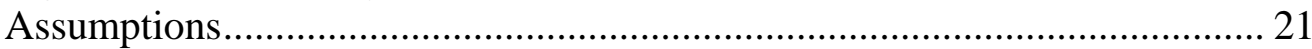

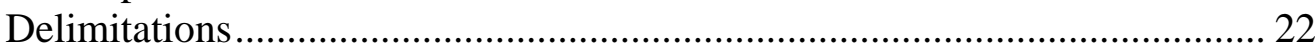

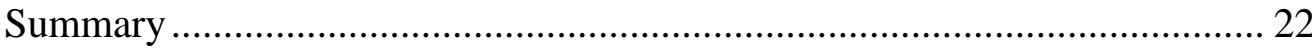

II. REVIEW OF LITERATURE ……………….......................................... 25

The South: A Brief Educational History ......................................................... 25

Changing Demographics: The Hispanic Boom .............................................. 27

Conceptual Framework .................................................................................. 35

Policies Affecting ELLs................................................................................ 36

Critical Theory and Tools for Liberation.................................................... 38

Policies Affecting Mainstream Students........................................................... 43

Student Achievement .................................................................................... 49

Candidates for Examination with the Conceptual Framework ......................... 51

Critical Literacy, Critical Pedagogy, and ELLs.......................................................... 61

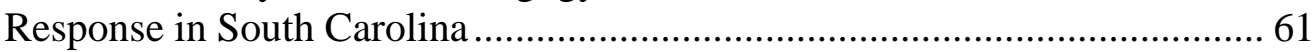

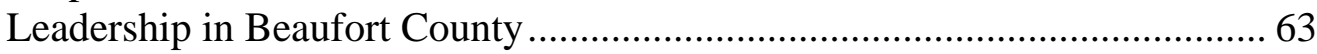

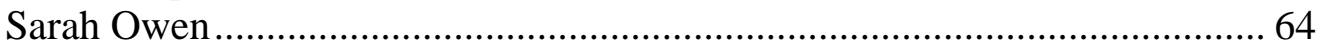

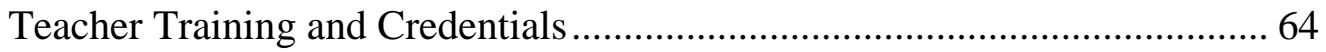

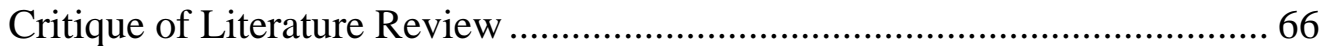

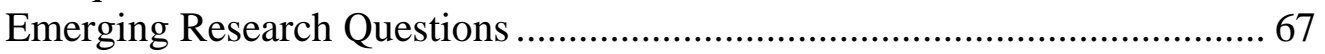

Summary of the Literature Review.................................................................. 69

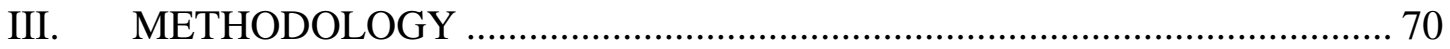

Theoretical Framework .............................................................................. 70

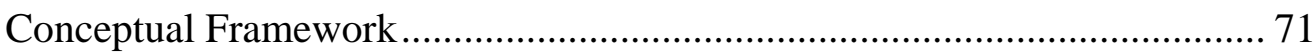

Rationale for Case Study ……………..................................................... 72

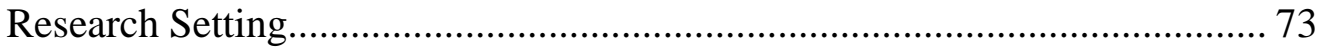

Population Sample …………………………………........................... 73

Research Design.................................................................................... 74

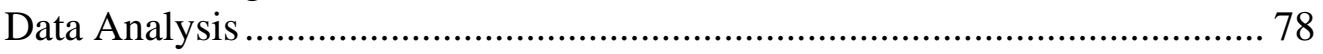

Interviews with ESL and Mainstream Teachers ............................................. 79

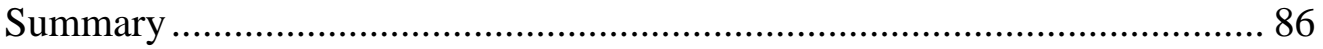




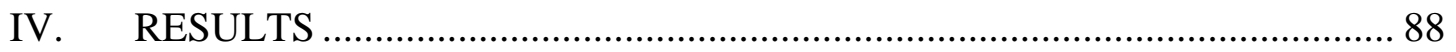

Hispanic Boom in Beaufort County........................................................... 88

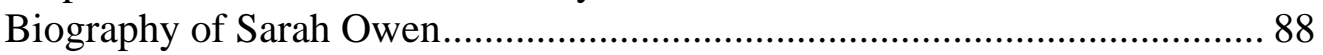

Beaufort County ESL before Sarah Owen....................................................... 89

After Sarah Owen ....................................................................................... 90

ESL Lead Teachers ...................................................................................... 95

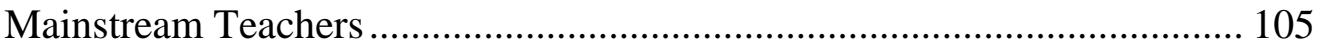

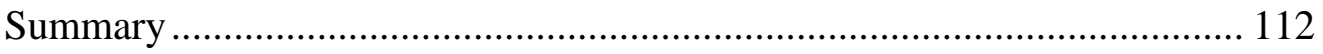

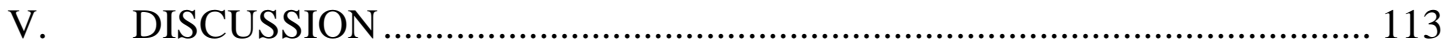

Analysis of Results Based on Conceptual Framework .................................. 113

ESL Leadership and Policy......................................................................... 114

Teacher Training and Feedback..................................................................... 118

Beaufort County ELLs and Critical Theory.................................................... 118

Implications Based on Emerging Themes ................................................... 128

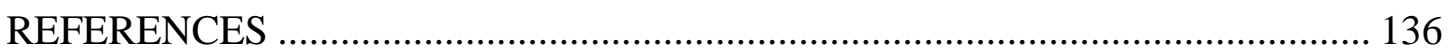

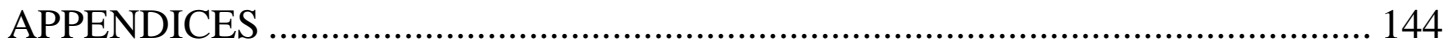

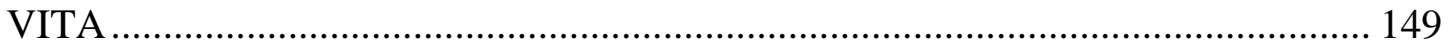




\section{LIST OF TABLES}

TABLE

PAGE

1. Growth of Hispanics in Beaufort County Schools.................................................. 6

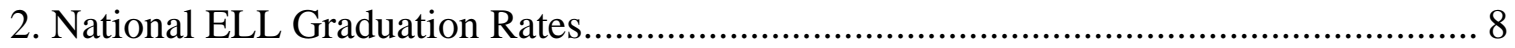

3. Percent of LEP students proficient on state assessments in math, Grade $4 \ldots \ldots \ldots \ldots \ldots . . . . . .10$

4. Percent of LEP students proficient on state assessments in math, Grade $8 \ldots \ldots \ldots \ldots \ldots . . . . . .10$

5. Percent of LEP students proficient on state assessments in math, high school ............ 10

6. Percent of LEP students proficient on state assessments in reading, Grade $4 \ldots \ldots \ldots \ldots . . .10$

7. Percent of LEP students proficient on state assessments in reading, Grade 8 .............. 11

8. Percent of LEP students proficient on state assessments in reading, high school ........ 11

9. Percent of LEP students proficient on state assessments in Beaufort County,

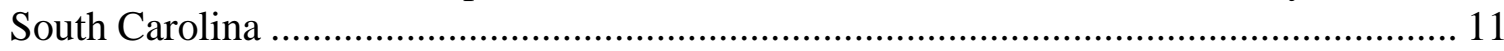

10. Hispanic Population Growth in South Carolina..................................................... 30

11. Hispanic Population Growth in Beaufort County, South Carolina............................. 32

12. States’ ELL Population Growth from 1995-2005 and 2005-2012........................... 33

13. Number of ELLs in New Settlement States of the South in 2012 ............................ 34

14. Growth of Hispanics in Beaufort County Schools................................................. 35

15. Summary of Commonalities Related to Underlying Conceptual Framework ........... 59

16. Summary of Promising Practices Related to Underlying Conceptual Framework..... 59

17. Eight Detrimental Factors Related to Underlying Conceptual Framework............... 60

18. Summary of Effective and Ineffective Strategies for ELLs.................................... 60

19. Garcia’s 8 Effective Strategies and Their Link to Student Success.......................... 61

20. Percent of LEP students proficient on state assessments in Beaufort County, South

Carolina when Sarah Owen was hired and after. 64 
21. Relationship between ESL teacher interview questions and conceptual framework and emergent research questions

22. Relationship between Mainstream Teacher Interview Questions and conceptual Framework and Emergent Research Questions 82

23. Percent of LEP students proficient on state assessments in Beaufort County, South Carolina before Sarah Owen hired as ESOL Coordinator and after in 2012

24. Percent of LEP students proficient on state assessments in Beaufort County, South Carolina before Sarah Owen hired as ESOL Coordinator vs. after she was hired and percentage change since 2005

25. ESL Lead Teacher Demographics …………………................................................... 95

26. Mainstream Teacher Demographics .................................................................... 106 


\section{LIST OF FIGURES}

FIGURE

PAGE

1. Map of South Carolina and Beaufort County, South Carolina .................................... 1

2. Map of Savannah, Georgia and Beaufort County, South Carolina............................... 6

3. Conceptual Framework for ELLs and Parallel Historical Structure for Mainstream

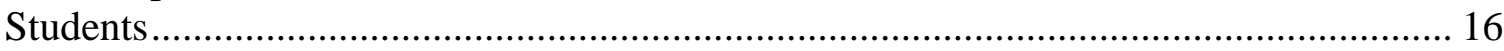

4. Conceptual Framework for ELLs and Parallel Historical Structure for Mainstream

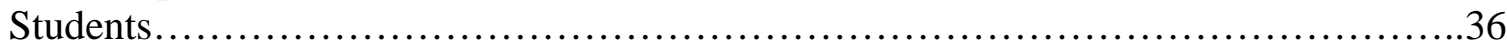

5. ELL Side of Conceptual Framework Underlying Representation ............................... 36

6. Historical Trends Affecting Mainstream Student Education .................................... 44

7. Application of Policy within the Conceptual Framework and Historical Trends......... 52

8. Application of Leadership within the Conceptual Framework and Historical Trends . 54

9. Application of Teacher Training within the Conceptual Framework and Historical

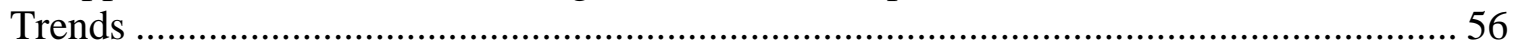

10. Relationship of Conceptual Framework to Emerging Research Questions................ 68

11. Conceptual Framework and Mainstream Historical Trends ................................... 71

12. Representation of Conceptual Framework and Mainstream Historical Trends........ 114

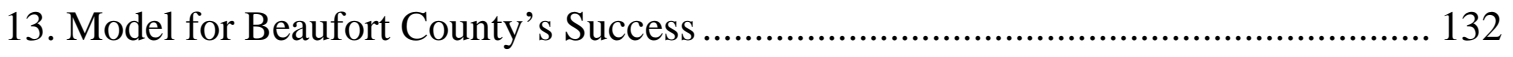




\section{CHAPTER I \\ INTRODUCTION}

Some school systems in the United States are experiencing a boom in certain student demographics throughout the country. This study focuses on one area -the district representing Beaufort, South Carolina and its environs -and how school systems in this area are dealing with a large influx of students who do not speak English as their first language. Unlike many school systems that have confronted the same issue, Beaufort County has done so successfully. English language learners in the Beaufort County school district have obtained award-winning results and achievements.

In order to analyze the success of this school system more effectively, this chapter presents the background, statement of the research problem, research questions, definitions, and purpose of the study.

\section{Background: The Slow Country}

Figure 1. Map of South Carolina and Beaufort County, South Carolina
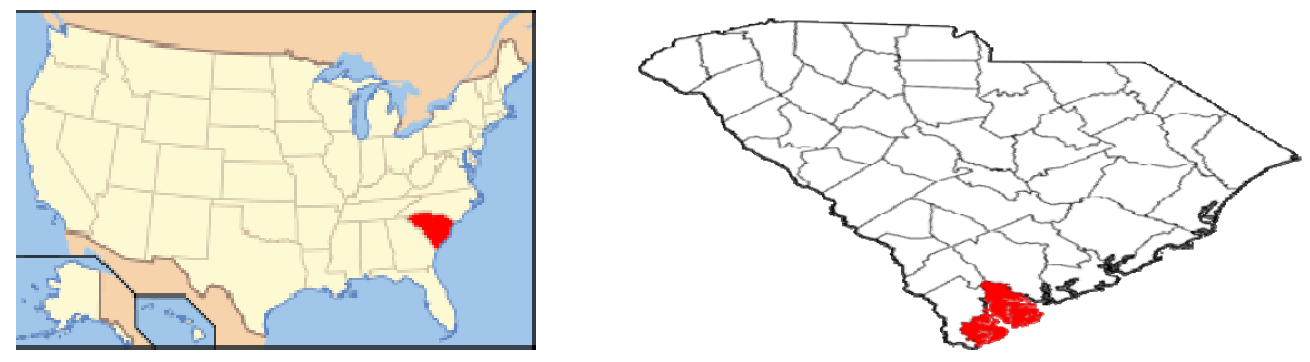

I was born and raised near the area of Beaufort County. The southern most areas of the state of South Carolina are often referred to as "The Low Country" because of the swampy marsh lands along the Atlantic Coast. Sometimes, that name is jokingly changed to "The Slow Country" to describe the area's culture and laid-back Southern influence. 
This Southern influence is seen most readily in the mannerisms of the people. For the most part, South Carolinians, and Southerners in general, are friendly and polite. They are rarely in a hurry. Even when in a hurry, true Southerners, regardless of race, still take the time to talk with friends and strangers alike and help whenever needed.

With respect to the inhabitants of Beaufort County, at least, until a few years ago they could be dissected in two primary groups: Caucasians and African-Americans. Although these two groups inhabited the same county, there was still much separation and division between them.

Many African-Americans in Beaufort County are Gullah or Gullah descendants. The Gullah are direct descendants of West Africans brought to the area as part of the slave trade. In various parts of South Carolina and Georgia, the Gullah live on barrier islands accessible only by boat. This isolation has allowed many Gullah to conserve their African language, customs, and traditions (Opala, 2007) ${ }^{1}$. As is the story in many parts of the Deep South, many African-Americans in Beaufort County still tend to be very poor and lack formal education.

With respect to the Caucasian members of Beaufort's communities, there is quite a mix of people and socioeconomic groups. Within Beaufort County lies Hilton Head Island, a famous golf and boating resort. It is not uncommon to see professional athletes, some of the US's wealthiest citizens, foreign dignitaries, or U.S. presidents (former or current) on Hilton Head Island. Many residents of Beaufort County regularly live in the

\footnotetext{
${ }^{1}$ When it was discovered that rice grew well in the swampy lands of Georgia and South Carolina, plantation owners needed slaves to work in the fields. They preferred slaves from the regions in Africa ranging from Senegal to Sierra Leone because they had experience working with rice. Due to the isolation of these slaves on the barrier islands from the 1700's up to current times, they have maintained many of their own Creole language, customs, music, dance, folktales, and rice-based diets that came with the Gullah from Africa (Opala, 2007).
} 
northern parts of the United States and own vacation homes in this part of South Carolina. Many of Beaufort County's inhabitants also moved to the area from the northern parts of the United States after retiring. Additionally, the Caucasians residents of Beaufort County come from many different socioeconomic groups and educational levels. In fact, the vast difference between the socioeconomic status of the Caucasian and African-American residents of Beaufort County is evident when looking at median incomes. According to 2010 U.S. Census Bureau statistics, the median income for a Caucasian in Beaufort County was $\$ 68,585$ annually whereas conversely, the average annual income of an African-American resident was only \$24,727 (USA.com, 2013).

The eclectic mixture of the location and the residents of Beaufort County make it range from a slow, rural southern town to a popular destination for tourists from all over the world. Until my departure from this area for South Florida in 1999, I recall seeing Hispanics or Latinos only on rare occasions in this part of the state. Of those I saw in the area, they most were likely to be Puerto Ricans stationed on the various military bases in the area as indicated by the military haircuts and uniforms.

Upon my return home in 2004, the influx of Hispanics was obvious. I was impressed any time I went to places where there were large public gatherings such as community events or even out shopping. There were always many Spanish speakers present, where few or none had been before. This obvious change in the population sparked my initial interest in this research area. ${ }^{2}$ The inhabitants of my native soil were no longer black or white, and I wanted to know why. Furthermore, as I had just moved

\footnotetext{
${ }^{2}$ I began to learn Spanish as a freshman in high school. I initially had no interest in the subject other than what was needed to complete my graduation requirements, but I fell in love with it. As a result, I took 3 years of Spanish in high school, obtained my Bachelor's and Master's degree in the subject, taught, and traveled extensively in Latin America.
} 
from a predominantly Spanish-speaking part of the country, I was interested in the impact of this change on my hometown community. My observation was corroborated by Larry Peterson (2011), who found that since 2000, the population of Savannah, Georgia, my hometown, would have actually decreased had it not been for new Hispanic residents settling in the area. Since the 2000 census, the Hispanic population of Savannah had more than doubled to 6,392 while the Caucasian and African-American populations have decreased. ${ }^{3}$

\section{Hispanics in Beaufort County Schools}

The growth in the number of Hispanics living in the state of South Carolina has also affected school demographics. The Beaufort County school system currently has the second largest number of English language learner (ELL) students in the state (See Table 1). During the 2010-2011 academic year in Beaufort County, Hispanic students made up approximately 20 percent of the school system's total enrollment. In Hilton Head, the Beaufort County golf and boating resort community previously mentioned, Hispanic students constitute 30 percent of the total student population. Furthermore, there are schools in the district where more than 50 percent of the total student enrollment are English Language Learners (ELLs) (Staff Reports, 2010).

The large number of Hispanics entering Beaufort County, South Carolina has not been welcomed with open arms in the community. In December 2006, the Beaufort County Council tackled the issue of illegal immigration in the county by unanimously passing the Lawful Employment Ordinance which went into effect on January 1, 2008.

\footnotetext{
${ }^{3}$ The southeastern border between the states of Georgia and South Carolina is formed by the Savannah River. Savannah (Chatham County) lies on the southern bank of the river and Beaufort County lies on the northern bank. Crossing the Savannah River heading north, one leaves Chatham County, Georgia and enters into Beaufort County, South Carolina.
} 
Under this new law, if a company applies for a license to operate in the county, the business owner(s),“must sign a form verifying, under penalty of perjury, they do not knowingly employ or plan to hire an illegal immigrant” (The Associated Press, 2006). The law would be enforced through an audit system which was predicted to review the immigration status of employees in approximately 5,000 Beaufort County businesses per year. Businesses found to knowingly hire undocumented workers faced very severe financial penalties or the revocation of their business license. However, many businesses that relied on immigrant labor were skirting the law by operating in the county without a license (Fox News, 2006).

The anti-illegal immigrant sentiments in the county did not stop with punishing those who hired illegal workers. In 2008, Beaufort County increased the power of local police officers to enforce federal immigration law. A total of 5 Beaufort County deputies received special federal training which gave them the authority to, "investigate a person's immigration status, identify those suspected of being in the country illegally, investigate crimes illegal immigrants are suspected of committing, (investigate) businesses identified by county auditors as possibly hiring illegal immigrants and, occasionally, participate in federal roundups in the area” (Brownstein, 2008). This new power manifested in a sting operation called Operation Surge in which anyone booked in the Beaufort County jail suspected of being in the country illegally was automatically reported to Immigration and Customs Enforcement (ICE). Operated Surge resulted in a total of 55 inmates, most of whom were jailed for traffic violations, being detained until their legal status could be verified by ICE. This operation was so stringent about not letting any suspected illegal 
immigrant escape verification that one gentleman was being held for fishing without a license (Brownstein, 2008).

Figure 2. Map of Savannah, Georgia and Beaufort County, South Carolina

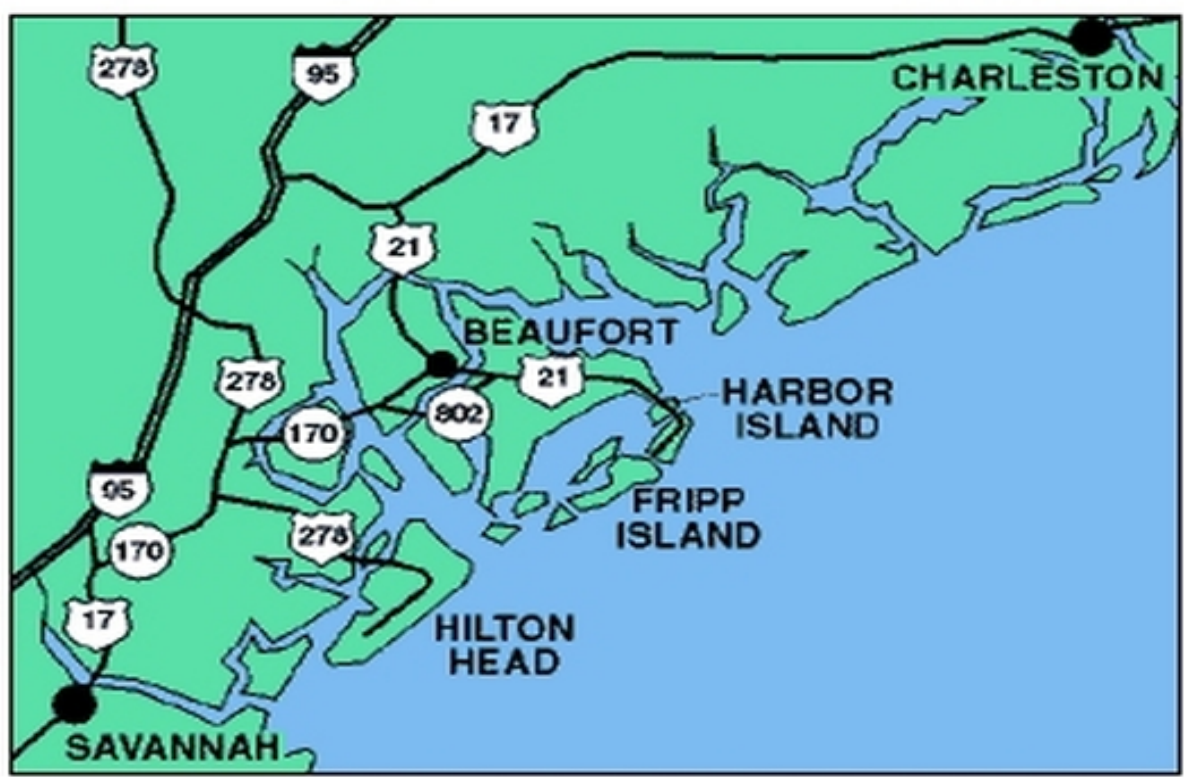

(Source: Google Maps, 2013)

Table 1. Growth of Hispanic Students in Beaufort County Schools

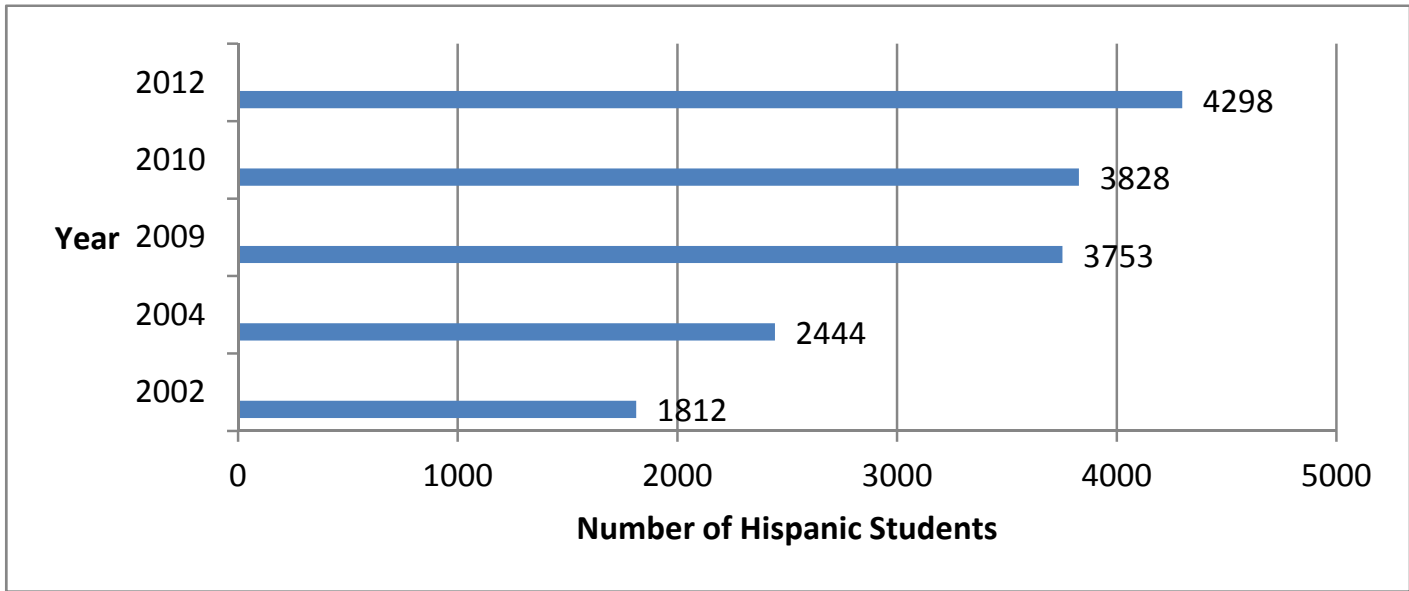




\section{Has the U.S. education system failed ELL students?}

In 1990, Lucas, Henze, and Donato observed,

for the growing numbers of Latino students in U. S. secondary schools, academic success has been elusive. Poor attendance records, low test scores, high drop-out rates, and small numbers going on to college all bear witness to schools' failure to meet their needs (p.1).

This trend continued in 2006 when the Oregon Department of Education reported that of its 129 school districts, only 22 met the minimum state requirements and achievement goals of ELL students. This constitutes a failure rate by over 80 percent of this state's districts. Additionally, recent statistics (Dungca, 2012) indicated that only 39 percent of Oregon's ELLs graduate from high school in 5 years. In the 2010-2011 academic school year, more than half of the states in the United States graduated less than $60 \%$ of their $\mathrm{LEP}^{4}$ student population. In the U.S. state with the largest number of English-language learners (ELLs), Nevada, only 29\% of ESL student population graduated. In the state of Arizona, the graduation rate for ELLs is described as "abysmal" as only $25 \%$ of these students complete high school (Romo, 2013). Conversely, the national graduation rate for native English speakers has hit a 40-year high with 75\% completing high school.

\footnotetext{
${ }^{4}$ English Language Learner (ELL) and Limited English Proficient (LEP) are terms used to refer to students who are learning English as a second language. ELL is the term favored by those in the field of teaching English as a Second Language (ESL); however, ELL and LEP are often used interchangeably.
} 
Table 2. National ELL Graduation Rates in the U.S.

\begin{tabular}{|c|c|}
\hline State & $\begin{array}{l}\text { Percentage of ELLs graduating in } \\
2010-2011\end{array}$ \\
\hline Vermont, South Dakota & $82 \%$ \\
\hline West Virginia & $79 \%$ \\
\hline Maine & $78 \%$ \\
\hline Arkansas & $76 \%$ \\
\hline Indiana, New Hampshire & $73 \%$ \\
\hline Tennessee & $71 \%$ \\
\hline Iowa, Kansas & $70 \%$ \\
\hline Illinois, New Jersey, Rhode Island & $68 \%$ \\
\hline Mississippi & $67 \%$ \\
\hline Wisconsin & $66 \%$ \\
\hline Delaware & $65 \%$ \\
\hline Pennsylvania & $63 \%$ \\
\hline Missouri & $62 \%$ \\
\hline Wyoming, Michigan, South Carolina & $62 \%$ \\
\hline North Dakota & $61 \%$ \\
\hline Hawaii, California & $60 \%$ \\
\hline Connecticut & $59 \%$ \\
\hline Texas & $58 \%$ \\
\hline Montana & $57 \%$ \\
\hline Massachusetts, New Mexico & $56 \%$ \\
\hline Virginia & $55 \%$ \\
\hline Maryland & $54 \%$ \\
\hline Ohio, Colorado, Florida & $53 \%$ \\
\hline Nebraska, Minnesota, Oregon & $52 \%$ \\
\hline Washington & $51 \%$ \\
\hline North Carolina & $48 \%$ \\
\hline New York & $46 \%$ \\
\hline Utah & $45 \%$ \\
\hline Louisiana & $43 \%$ \\
\hline Alaska & $41 \%$ \\
\hline Alabama & $36 \%$ \\
\hline Georgia & $32 \%$ \\
\hline Nevada & $29 \%$ \\
\hline Arizona & $25 \%$ \\
\hline
\end{tabular}

(Source: http://matsolnews.wordpress.com/2012/11/26/mass-ell-graduation-rate/)

Another issue plaguing success for ELLs in U.S schools is a disproportionately high dropout rate. When compared to their English-speaking counterparts, ELLs are the group of students most likely to drop out of school before the $12^{\text {th }}$ grade. In the United 
States, the ESL student dropout rate is currently hovering at 60 percent. In New York City, the dropout rate increases to a staggering 76 percent for ESL students (Lopez, 2008). When asked why this phenomenon occurs with ELLs, educators responded that recently enacted higher requirements and standards for graduation were partly to blame. Mayor Michael Bloomberg elaborated further on the high dropout rate of ELLs in New York City when he acknowledged that the majority of these students are located, “...in a handful of New York City's most underserved and under-resourced public schools” (Romo, 2013).

\section{Hispanic Student Achievement in the South and South Carolina}

In Tuscaloosa, Alabama, 6 schools are currently the focus of initiatives to improve ESL student performance on the Alabama Reading and Math Test (ARMT), Alabama’s criterion-referenced test for grades 3-8. During the 2009-2010 academic year, only 60 percent of ESL students passed the ARMT for math and approximately 72 percent passed it for reading. These numbers fell dramatically during the 2010-2011 academic year to 51 and 50 percent, respectively (Tuscaloosa City Schools, 2011).

When looking at the pass rates of each state's standardized test, LEP students in the Deep South run a very wide gamut. States such as South Carolina, North Carolina, and Georgia post numbers that are very encouraging overall. However, the states of Alabama, Tennessee, Kentucky and Mississippi show very disappointing pass rates in the subject areas of math and science when tested in grades 4,8 , and high school. 
Table 3. Percent of LEP students proficient on state assessment in math, Grade 4

\begin{tabular}{|l|l|l|}
\hline State & $\mathbf{2 0 0 9 - 2 0 1 0}$ & $\mathbf{2 0 1 0}-\mathbf{2 0 1 1}$ \\
\hline South Carolina & $83.2 \%$ & $78 \%$ \\
\hline North Carolina & $68.6 \%$ & $72 \%$ \\
\hline Tennessee & $13.5 \%$ & $16 \%$ \\
\hline Alabama & $67.8 \%$ & $64 \%$ \\
\hline Georgia & $70.8 \%$ & $75 \%$ \\
\hline Kentucky & $56.8 \%$ & $52 \%$ \\
\hline Mississippi & $54.4 \%$ & $56 \%$ \\
\hline
\end{tabular}

Table 4. Percent of LEP students proficient on state assessment in math, Grade 8

\begin{tabular}{|l|l|l|}
\hline State & $\mathbf{2 0 0 9 - 2 0 1 0}$ & $\mathbf{2 0 1 0 - 2 0 1 1}$ \\
\hline South Carolina & $68.2 \%$ & $65 \%$ \\
\hline North Carolina & $69.1 \%$ & $67 \%$ \\
\hline Tennessee & $5.5 \%$ & $8 \%$ \\
\hline Alabama & $59.5 \%$ & $49 \%$ \\
\hline Georgia & $65.9 \%$ & $68 \%$ \\
\hline Kentucky & $26 \%$ & $25 \%$ \\
\hline Mississippi & $47 \%$ & $53 \%$ \\
\hline
\end{tabular}

Table 5. Percent of LEP students proficient on state assessment in math, high school

\begin{tabular}{|l|l|l|}
\hline State & $\mathbf{2 0 0 9 - 2 0 1 0}$ & $\mathbf{2 0 1 0 - 2 0 1 1}$ \\
\hline South Carolina & $54.4 \%$ & $36 \%$ \\
\hline North Carolina & $52.9 \%$ & $52 \%$ \\
\hline Tennessee & $3.6 \%$ & $20 \%$ \\
\hline Alabama & $72.2 \%$ & $64 \%$ \\
\hline Georgia & $50.3 \%$ & $62 \%$ \\
\hline Kentucky & $14.3 \%$ & $17 \%$ \\
\hline Mississippi & $63.4 \%$ & $77 \%$ \\
\hline
\end{tabular}

Table 6. Percent of LEP students proficient on state assessment in reading, Grade 4.

\begin{tabular}{|l|l|l|}
\hline State & $\mathbf{2 0 0 9 - 2 0 1 0}$ & $\mathbf{2 0 1 0 - 2 0 1 1}$ \\
\hline South Carolina & $75.6 \%$ & $70 \%$ \\
\hline North Carolina & $35.7 \%$ & $39 \%$ \\
\hline Tennessee & $10.3 \%$ & $12 \%$ \\
\hline Alabama & $68.5 \%$ & $65 \%$ \\
\hline Georgia & $82.4 \%$ & $81 \%$ \\
\hline Kentucky & $63.2 \%$ & $49 \%$ \\
\hline Mississippi & $36.7 \%$ & $39 \%$ \\
\hline
\end{tabular}


Table 7. Percent of LEP students proficient on state assessment in reading, Grade 8.

\begin{tabular}{|l|l|l|}
\hline State & $\mathbf{2 0 0 9 - 2 0 1 0}$ & $\mathbf{2 0 1 0}-\mathbf{2 0 1 1}$ \\
\hline South Carolina & $64.7 \%$ & $59 \%$ \\
\hline North Carolina & $30.3 \%$ & $26 \%$ \\
\hline Tennessee & $1.7 \%$ & $4 \%$ \\
\hline Alabama & $34.1 \%$ & $33 \%$ \\
\hline Georgia & $78.1 \%$ & $78 \%$ \\
\hline Kentucky & $38.9 \%$ & $33 \%$ \\
\hline Mississippi & $15.5 \%$ & $22 \%$ \\
\hline
\end{tabular}

Table 8. Percent of LEP students proficient on state assessment in reading, High School.

\begin{tabular}{|l|l|l|}
\hline State & $\mathbf{2 0 0 9 - 2 0 1 0}$ & $\mathbf{2 0 1 0 - 2 0 1 1}$ \\
\hline South Carolina & $36.8 \%$ & $36 \%$ \\
\hline North Carolina & $18.4 \%$ & $16 \%$ \\
\hline Tennessee & $12.3 \%$ & $8 \%$ \\
\hline Alabama & $37.9 \%$ & $33 \%$ \\
\hline Georgia & $65.6 \%$ & $68 \%$ \\
\hline Kentucky & $15.5 \%$ & $21 \%$ \\
\hline Mississippi & $31 \%$ & $31 \%$ \\
\hline
\end{tabular}

(Source: www.eddatexpress.ed.gov/state-tables.report.cfm)

Table 9. Percent of LEP students proficient on state assessments in Beaufort County, South Carolina

\begin{tabular}{|l|l|l|}
\hline Assessment & $\begin{array}{l}\text { Beaufort County, South } \\
\text { Carolina in 2005 }\end{array}$ & $\begin{array}{l}\text { Beaufort County, South } \\
\text { Carolina in 2012 }\end{array}$ \\
\hline $4^{\text {th }}$ Grade Reading & $33.3 \%$ & $64 \%$ \\
\hline $4^{\text {th }}$ Grade Math & $41.3 \%$ & $72.8 \%$ \\
\hline $8^{\text {th }}$ Grade Reading & $12.2 \%$ & $48.3 \%$ \\
\hline $8^{\text {th }}$ Grade Math & $14.1 \%$ & $48 \%$ \\
\hline $\begin{array}{l}\text { High School Assessment } \\
\text { Program (HSAP) }\end{array}$ & $36.0 \%$ & $87.3 \%$ \\
\hline
\end{tabular}

(Source: www.ed.sc.gov/data/pass/2012/show_state_pass_scores_demo.cfm?ID=999999 and www.eddataexpress.gov)

\section{Beaufort County and ESL student achievement}

Like many school systems in the South and other parts of the United States, the ELL (English Language Learner) population of Beaufort County schools has more than doubled (See Table 1). Unlike many of these other school systems, the Beaufort County School System has been honored to receive both statewide and national recognition for 
the progress made by Hispanic students. During the 2009-2010 academic year, more than half of Beaufort County schools earned Palmetto Gold or Silver awards which are given to schools within the state of South Carolina that close achievement gaps for minority and/or low-income students as well as students with disabilities (Cerve, 2011). Beaufort County schools were also recognized for successfully meeting Annual Yearly Progress $(\mathrm{AYP})^{5}$ goals for ESL students in every elementary and middle school in the county. Moreover, Beaufort County ESL students posted one of the highest rates of progression ever recorded for ELL students on the state’s English proficiency exam (Truesdale, 2010). Even more impressive is the fact that in 2010, approximately 70\% of all ELL students in the county passed the High School Assessment Program (HSAP), a task necessary for a student to graduate with a state high school diploma. During the 20112012 school year, the pass rate of ELL students on the HSAP in Beaufort County jumped to a staggering 87.3\% (2012 Annual Report Card). In 2006, the Fordham Report recognized achievement tests scores from South Carolina and, "It’s burgeoning Hispanic population that performs better than the same population in most other states” (p. 102). Furthermore, Hispanic students in the recognized Beaufort County Schools performed equally as well as their Caucasian counterparts on South Carolina’s standardized achievement tests (Staff Reports, 2005). Additionally, double-digit gains were posted for third-eighth grade ELL students in the areas of Language Arts and Science from 20062008 in Beaufort County on the Palmetto Achievement Challenge Test (Wright, 2011).

\footnotetext{
${ }^{5}$ AYP is Adequate Yearly Progress. These are goals that each individual school sets for student achievement and performance. If a school does not meet its goal for AYP on standardized achievement test, it can negatively impact the amount of federal funding the school receives.
} 
The success rate for ELL students in the Beaufort County schools system was confirmed by an additional outside educational consulting firm in 2011. While presenting the findings of the study to school board, the lead consultant, Jennifer Coleman, stated, "whatever the Beaufort County School District is doing to reach and teach its students who are still learning English, it’s time to bottle the successful formula” (Wright, 2011). With respect to student graduation and dropout rates, $60 \%$ of Beaufort County's ELL student population graduates on time. Moreover, they post one of the lowest dropout rates in the state and country with only $1.9 \%$ of the LEP population dropping out before graduation (2011 State Report Card).

Certain states in the Deep South such as Tennessee, Kentucky, and Alabama have posted dismal numbers with respect to the percentage of ELL students considered proficient on standardized tests. Alabama, North Carolina, and Georgia have also seen less than 50\% of their ELL student populations graduate. However, the statistics on Beaufort County school system's ELL students present a noticeable discrepancy to the field of ESL education. This school system has posted award-winning results for student proficiency and has bucked the trends with respect to graduation and dropout rates. This relatively small school system has seemingly done something very right in its approach to ESL student education. Therefore, I would like to look at what this schools system has done that others have not. Additionally, I would like to know what aspects from their approach could have wide-spread applications throughout the United States.

\section{Statement of the Research Problem}

The boom of Hispanics is changing the population of the United States; thus, school demographics are changing accordingly. In 2006, Zehr reported that Hispanic 
students accounted for two-thirds of the enrollment growth in U.S. schools during that same year. However, she reports that only a very small percentage of the nation's schools are actually seeing this growth (p. 1). This scenario is further complicated by the fact that the success rate for ELLs in many school districts, even those with a long-standing history of working with ESL students, is very low. Despite large amounts of research on how to successfully educate and accommodate these students successfully in U.S. schools, the school systems in many states are failing at the task. The arrival of a large number of ELLs has been a recent phenomenon in the Beaufort County, South Carolina school district; nevertheless, ELLs have a high rate of success in a relatively short amount of time. Understanding the impact and reaction of the most basic and essential elements of students' education -the teacher- is particularly important. By gaining a better understanding of teachers' views, perceptions, outlooks, and concerns regarding the potential challenges represented by the increasing number of English Language Learners (ELLs), other school systems could benefit from the teachers' insight regarding the scope of the problem and potential avenues for addressing it. Additionally, ESL student policies are created by a school system's leadership. Therefore, it is also important to take a look at the role of Beaufort County's ESL leadership in the application of existing policies and currently pedagogical approaches.

Krashen (1981) and Garcia (1999) both stress the importance of teacher attitudes and their effects upon students' self-esteem, motivation, and anxiety (Smith, 2004, p. 1). In a study conducted by Smith (2004), the gamut of teacher attitudes toward English as a Second Language (ESL) students ranged from, "I should not have to deal with the” to "I really understand the difficulties that an ESL student faces” (p.2). Some of the comments 
provided by survey participants included, “[Mainstreaming ESL students] slows the whole class down” and “they wouldn’t accommodate their classrooms for us” (p. 1). With such a wide spectrum of teacher attitudes, we should consider how these attitudes are manifested in the classroom and if teacher training is important in shaping them.

The Beaufort County school system’s approach to an ESL population boom has resulted in academic success among its Hispanic students and ELLs. The recommendations made by many experts and theorists in language acquisition on the process necessary to accommodate ELLs into mainstream U.S. classrooms will be explored further in Chapter II. However, this study will attempt to ascertain what Beaufort County's successful formula is from the people responsible for applying it -the teachers and the ESL program leadership. Does this school system follow the steps recommended by language experts or is some other influence, such as teacher attitude or political environment, responsible for Beaufort County’s success?

\section{Theoretical Framework}

When looking at the various influences that help manifest student achievement in the U.S. schools, many sources such the teachers, stakeholders, community leaders, and national trends play critical roles. There are additional sources that influence ELL student achievement because this group of students is governed by not only federal laws and trends that exist for all mainstream students, but they are also governed by the federal laws and trends implemented specifically to aid student achievement for ELLs in U.S. schools. Based on this information, I have constructed the following conceptual framework representation in figure 3 below. On the left, this conceptual framework represents the laws and policies that exclusively influence ELL educational experiences 
in schools while still relying on the federal requirements for student achievement. The right side of the figure shows the parallel historical trends, national policy and laws that influence how teachers impart education in mainstream classrooms. With this representation, I suggest that attention must be paid to both sides of the model for ELL student achievement to occur. (This figure is discussed in further detail in Chapter 2).

Figure 3. Conceptual Framework for ELLs and Parallel Historical Structure for Mainstream Students
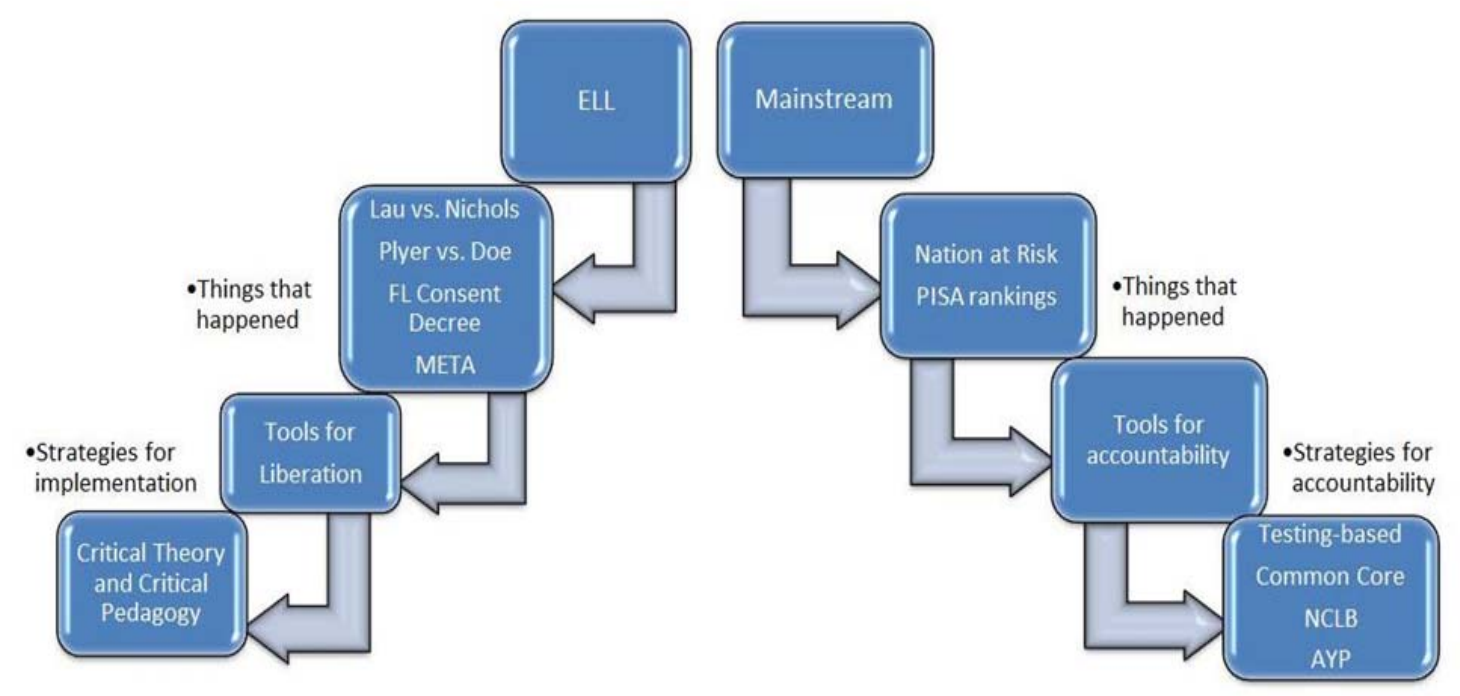

While this conceptual framework illustrates the current state of student achievement in U.S. schools, the statistics previously mentioned in this chapter illustrate that the success of ELLs in the Beaufort County, South Carolina school district would indicate that they are having a very different experience than most ELLs in U.S. schools. Given the contradictory situation of ELLs in Beaufort County, this study will be guided by the critical theory, which Gall, Gall, and Borg (2003) define as

the formulation of principles designed to clarify the power relationships and forms of oppression existing in a society or culture, and thus to serve as a guide to efforts to emancipate its members from those forms of 
oppression (p. 622).

The ELLs of Beaufort County have seemingly found a way to rise above the cycle of failure and oppression that many other ELLs are experiencing in U.S. schools. As a result, this study will utilize critical theory and two of its penchants, critical literacy and critical pedagogy, to see what role they have played in the success of ELLs in Beaufort County.

\section{Beaufort County Timeline}

As previously illustrated in Table 9, the ELLs of Beaufort County, South Carolina have made significant gains in reading, math, and the HSAP between 2005 and 2012. This study will analyze what role, if any, a 2006 change in ESOL leadership played. In September 2006, Sarah Owen was hired as the Coordinator for ESOL, Gifted, and World Languages. The significant improvements and award-winning gains have occurred under her administration as the ESOL coordinator. Therefore, the role of leadership must also be included as a possible tool of liberation in the conceptual framework.

\section{Research Questions}

Based on the conceptual framework of this study and critical theory, the research questions for this study will be guided by 3 concepts: ESOL leadership in Beaufort County, critical literacy, and critical pedagogy. With respect to leadership, the positive changes took place as a new coordinator moved into the position. Therefore, a change in leadership could be the catalyst for ESL student success in Beaufort County. However, the teachers are responsible for executing the curriculum as well as policies leadership’s policy in each classroom. Therefore, the teachers will be necessary to provide information on the roles of critical literacy and critical pedagogy in the classroom. As a 
result, this study will seek to ascertain how these three factors separately or symbiotically contributed to the success of ELLs in Beaufort County.

This study will be guided by the following questions:

1) What role has the ESL policy and leadership played in the success of Beaufort County's ELL students?

2) How have the teachers of Beaufort County contributed to the success of Beaufort County's large ELL population?

3) What teaching methodologies and approaches are the teachers of Beaufort County using that are work well for ELL students?

\section{Definitions}

For the purposes of this research study, the following definitions and abbreviations will be used:

Accommodation. Modifications or adjustments made in a student's environment, instruction, and performance expectation that give the student the opportunity to achieve individual goals based on reasonable expectations after assessments (www.parrotpublishing.com/Inclusion).

Adequate Yearly Progress (AYP). A measure of progress made by students based on standardized test results. If a school does not meet its annual goals for AYP, it could impact the amount of federal funds the school receives (California Department of Education, 2012).

Alabama Reading and Math Test (ARMT). This is the criterion-referenced test given to 3-8 graders in the state of Alabama.

English as a Second Language (ESL). Also, English for Speakers of Other Languages (ESOL) are the terms used interchangeably to describe English language instruction for nonnative speakers (TESOL, 2004) 
English Language Learner (ELL). Students who have limited or no English skills and who are in the process of learning English (Gollnick \& Chinn, 2009).

High School Assessment Program (HSAP). This is the assessment given in the state of South Carolina in order for students to graduate with a high school diploma.

Hispanic or Latino. These terms refer to a person of Mexican, Puerto Rican, Cuban, South or Central American, or other Spanish culture or origin, regardless of race (Office of Management and Budget, 1997).

Limited English Proficient (LEP). A student whose dominant language is not English and whose difficulties speaking, reading, writing, or understanding English may be sufficient enough to deny the student the ability to achieve successfully in a classroom where the language of instruction is English (www.doe.gov) ${ }^{6}$

Mainstream. An educational setting in which the majority of the pupils do not have special needs or require special education. It can also mean to place a child with special educational needs in a regular classroom setting (www.merraim-webster.com).

Palmetto Achievement Challenge Test (PACT). This is the statewide assessment given to all 3rd-8th graders in the state of South Carolina. It measures to what degree students have met state standards (www.ed.sc.gov).

Population Boom. The change in a population over time, and it can be quantified as the change of the number of individuals...using "per unit time" for measurement (www.wikipedia.org/population)

\footnotetext{
${ }^{6}$ Limited English Proficient (LEP) is a term that has fallen out of favor with the field of ESOL, but it is still used and found in the literature from many states' departments of education. English Language Learner (ELL) is the term currently preferred.
} 
Success. For the purposes of this study, the definition of success will have a political orientation. Success is the degree to which an individual student meets the goals necessary for a school to make Adequate Yearly Progress. This is usually measured by a certain percentage of a school population passing a standardized assessment.

\section{Purpose}

The purpose of this study is to examine how a boom in the number of immigrants, who do not speak English as their first language, seemingly has been successfully accommodated into a local, primarily English-only school system, when numerous systems of similar structure have fared far less well. This phenomenon relates to quickly changing demographics in the Deep South. In fact, some states have already seen dramatic changes in their student populations while others are just now beginning to experience it. The Beaufort County, South Carolina school system has a short history of working with a large number of ELLs; however, unlike many of its peer systems, it has done so quite successfully. This school system has accomplished what others with much longer histories of working with ELLs have not. As a result, this study will seek to find distinctions as to why the Beaufort County school system has been successful with such a large number of recently arrived ELL students from the teachers responsible for educating them.

As the Hispanic population in the United States continues to grow, more school systems throughout the country will face challenges of adequately educating ELL students. Examining the views of teachers who have been directly impacted by a large influx of Hispanic students could provide insights that would facilitate the development of a model for successfully confronting large demographic changes in student 
populations and for successfully accommodating large ESL populations in U.S. schools. Additionally, knowing what ESL training teachers found beneficial, when working with large ELL populations, particularly those arriving to small environs, is important.

\section{Significance to theory and practice}

Given that this will be a more focused study, the actual population is represented by any geographic area that has experienced recent increases in the number of ESL students. While this study will focus upon the "Hispanic population boom" in one state based upon examining the input of teachers from one county, one should note that the phenomenon being investigated is not isolated to only the state of South Carolina. As the population of the United States continues to change, more and more school systems likely will face the issue of accommodating more ELL students in classrooms. The experiences of teachers in the Beaufort County School System may serve as a model for other teachers facing the same issues, in other areas. Based upon the experiences of the Beaufort County teachers, other teachers and school systems may be able to successfully accommodate increasing numbers of ELL students. Additionally, they may learn what training and what support from ESOL leadership best helps teachers prepare for large ELL student populations.

\section{Assumptions}

The proposed study is based upon the following assumptions:

1) The case study results will provide accurate data regarding teachers' experiences with LEP students.

2) The associated school system will support this research by encouraging its teachers to participate in the study. 
3) Teachers and stakeholders will measure "success" in terms of whether or not their respective schools make AYP.

\section{Delimitations}

The following are delimitations for the proposed study:

1) The proposed sample for this study is limited to one county school system within the "Low Country" of South Carolina.

2) Because this study will be based on case study interviews, the information and perspectives provided by the case study participants will be limited to their personal experiences and to their exposure to ESL students.

3) For this study, student achievement will refer to the results most important to stakeholder, such as meeting AYP requirements. This study does not intend to undermine other forms of student achievement and evaluation such as portfolios.

4) The data provided by the Sarah Owen will reflect the experiences with respect to only a single leader in the Beaufort County school system.

\section{Summary}

During the past decade, Beaufort County has seen a dramatic change in the population of its residents. Along with the Caucasian and African-American members of the community, the county was also impacted by a boom in the Hispanic population. This impact of the changing population was also reflected in the student demographics of Beaufort County Schools, and it brought along a separate set of issues. Some of these issues included learning quickly to accommodate a large ELL population in the classroom where almost none had previously been present. Given that the teachers of 
Beaufort County have confronted the issue of the changing U.S. population and its potential effects on local school systems, the results of this study could serve as a model for other school systems, which have yet to be impacted by a changing student population. The teachers of Beaufort County can provide first hand input on the types of issues they encountered when suddenly faced with teaching a large ELL population. They also can detail what training, approaches, or teaching methodologies they found useful when working with ELLs. Furthermore, the teachers can describe what, if any, attitude changes they felt when placed in a classroom with a student population in which they may not have been experienced with or accustomed to teaching previously.

Hispanics and Latinos accounted for more than $50 \%$ of the total population growth in the United States from 2000-2010 (U.S. Census Bureau, 2010). Additionally, Hispanic/Latino students are also the largest and fastest growing minority group among school-age children in the United States (Smith-Adcock, et. al, 2004, p.1). As the population of this country continues to change, other schools systems likely will see the transformations in student demographics the Beaufort County school system has faced. The findings of this case study may be important as they might help provide a plan and serve as a guide for other school systems, particularly those that are not accustomed to large ELL populations, as they potentially will face the effects of a boom of ELLs. This study could provide first hand insight from those directly impacted by the large ELL population, the teachers, as to what training and approaches worked well in Beaufort County and what did not during this process. Finally, the study will detail what measures were taken in Beaufort County to accommodate a large ELL population while still providing all students with a quality education. 


\section{Organization of the Study}

In Chapter I of the study, the background on the issue of the changing U.S. population, the boom of the Hispanic population in the U.S. and South Carolina, the research problem, and research questions were introduced. The significance of this study, delimitations, and definitions were also discussed. Chapter II is a review of the literature that supports this type of study. Chapter III is a description of the various methods utilized to collect the data. Chapter IV is a presentation of the findings and results. Chapter V is the discussion of the findings and their implications for possible further research in the field of English as a Second Language. 


\section{CHAPTER II}

\section{REVIEW OF LITERATURE}

This chapter will review the literature relevant to this area of research and this study. It will begin by taking a look a brief educational history of the south based on Knight's fundamental description, the boom in the Hispanic population of the United States and how it affected U.S. school systems, significant events in the history of bilingual education, and respectful language teaching practices. The second part of the chapter will focus on the conceptual framework with respect to common practices and leadership in language education in the Deep South.

\section{The South: A Brief Educational History}

\section{The early years}

The beginning of public education in the Deep South of the United Sates is directly related to the expansion of England into the New World during the seventeenth century and the establishing of its colonies in these newly discovered areas. The initial forms of education in the southern colonies were simply a, "transplanting of European traditions and customs” (Knight, p. 2). During this time, the population of England and the colonies was divided into two classes: the independent, wealthy class and the dependent, working class. The members of the independent class included noble men, the clergy, lawyers, shopkeepers, and gentlemen. The dependent class included apprentices, vagrants, journeymen, and common laborers. The employment and migration of the lower class depended upon the whims of their respective feudal lords. This societal organization was transferred into the English colonies and later into the colonial education system. The land-owning, planter class became the distinguished upper class of 
the Southern colonies while the lower class consisted of indentured servants and slaves. With respect to the educational system, the prevalent educational system in the 13 colonies was the classical Latin grammar school where elementary mathematics and the classics were taught.

Due to the prevalent Puritan beliefs in England and its colonies at the time, education was believed to be a necessary tool for all people. However, Puritans also believed the type of education a person received should be determined by his/her position in society. This meant that only the upper classes received secondary and higher forms of education. The lower classes, the poor, servants, and those without higher forms of formal education relied on apprenticeships after grammar school.

Around 1750, "the academy" became the main form of secondary education after grammar school (Knight, p. 73). The academies were highly popular in the South until after the Civil War when they began to morph into public high schools from 1860-1900. The academies that survived the transition became known as preparatory schools and were reserved only for the upper class. It was also during this time that the idea of a free secondary public education at the public's expense became more widely accepted throughout the United States (Knight, p. 109). During periods of reform and transition for the U.S. education system, the South was slow at adopting change and supporting free public education for all due to the belief that "a state-supported and state-controlled school system for all children would make education too common, serve to change the social status of those whose social status was fixed, and break down certain social barriers” (Knight, p. 264). 
After the 1896 Supreme Court decision in Plessy v. Ferguson legalized racial segregation on railway cars, this decision was carried over into public schools (ARC, 2012). As a result, public schools for African-Americans received substantially less funding than those for Caucasian children. This slowly began to change in the South from 1930-1950. During these years, the South began to realize that it was losing AfricanAmerican laborers to cities in the North. Additionally, the NAACP filed several lawsuits in South states against the inequality of white and black schools. As a result, more money was invested in schools for African-American children (ARC, 2012).

Up until 1945, the majority of Southern students only completed the $8^{\text {th }}$ grade; however, this began to change after World War II. The end of World War II and the beginning of the Cold War and Space Race were impetuses the South, along with the rest of the United States, needed to make them focus on the importance and the role of equal education for all children. Although the South was much slower at accepting the idea of a free education for all and was still highly segregated, a study by James Coleman found that by 1966, most U.S. schools spent equal amounts of money on white and black students. The same study by Coleman also found that background and socioeconomic status played a more important role in determining student success than the amount of money spent per student (Coleman, 1966).

\section{Changing Demographics: The Hispanic Boom}

\section{The United States}

The United States is and always has been a country of immigrants. While most immigrants to the country have come from European nations, that trend has changed in recent years. In 2003, Fletcher and Navarrete reported that $85 \%$ of new residents to the 
U.S. are arriving from Latin America and Asia (p. 2). In 2008, the U.S. Census Bureau found the United States boasted the second largest Hispanic ${ }^{7}$ population in the world (46.9 million), surpassed only by Mexico (110. million) (NBC-2, 2010; U.S. Census Bureau, 2000).

The U.S. Hispanic population is increasing by approximately $3.4 \%$ per year, a growth rate that makes Hispanics the largest and fastest growing minority group in the United States (U.S. Census Bureau, 2006). From 2000-2010, the increase in the Hispanic population within the United States constituted 39\% of the country’s total population growth. In 2003, the U.S. Census Bureau found Latino/Hispanics to be the largest minority group in the United States and growing at rates 3 to 5 times faster than any other group.

The boom in the Hispanic Population in new settlement areas first became evident during the 2000 U.S. Census. In the U.S. Census Brief (2000), the Hispanic population had greatly increased in "nontraditional Hispanic states” such as North Carolina, Georgia, Iowa, Arkansas, Minnesota, and Nebraska (p. 5). In these states, certain counties experienced a boom in the Hispanic population that ranged from $6.0 \%$ to $25.9 \%$ (U.S. Census Brief, 2000, p. 5). As a result of these numbers, the increased Hispanic population in these particular counties of the nontraditional Hispanic states exceeded the overall growth rate of the total population in these states. Later in the decade, other non-

\footnotetext{
${ }^{7}$ Hispanic refers to the heritage, nationality group, country of birth, lineage, or the country of birth of a person's parents. This race designation is also used interchangeably with terms "Spanish" and "Latino" Those who designated themselves as Hispanic, Spanish, or Latino can be of any race. These three terms refer to U.S. Census Bureau participants who identify themselves as being from Mexico, Cuba, The Dominican Republic, Puerto Rico, Central America, South America, or Spain. These terms do not refer to the language(s) spoken by the survey participants.
} 
traditional states such as Alabama and Arkansas were added to the list, and the same phenomenon occurred.

As an example, in Tuscaloosa, Alabama, the total number of Hispanics in the county increased 76\% in ten years. From July 2008 through July 2009, the Hispanic population of Tuscaloosa County also mirrored what had happened in other nontraditional Hispanic states; the growth in the Hispanic sector of the population alone far exceeded the numbers posted in overall population growth for the county (Jones, 2010). Finally, between July 2007 and July 2008, North and South Carolina were the two states with the highest percentage increases in the number of Hispanics with 7.4\% and 7.7\%, respectively (NBC-2, 2010).

\section{The South}

Many Hispanics are now settling in areas coined by Zehr (2006) new settlement states by Zehr such as Alabama, Arkansas, Georgia, North Carolina, South Carolina, and Tennessee (p. 2). These six states have all seen their Hispanic population increase at least 200\% since the 1990s. The state with the largest amount of growth, North Carolina, saw a population increase of almost $400 \%$ with respect to Hispanics. As a result, the South is now the second largest living area for Hispanics in the United States and contains the fastest growing Hispanic populations in the United States (Young, 2005).

\section{South Carolina}

The state of South Carolina has experienced a marked increase in the number of Hispanics, within its borders. From 1990-2000, the overall Hispanic population of the state increased $211.7 \%$. Furthermore, this population continued to grow an additional 35.7\% between 2000 and 2004, making it the fastest growing ethnic group in the state 
(Young, 2005). In 2008, U.S. Census Bureau statistics indicated that Hispanics in South Carolina had the largest overall percentage growth of any state in the country (Gray, 2008). Between 1990 and 2007, the overall growth of the Latino population in South Carolina increased over $460 \%$ with some individual countries seeing an increase of $150 \%$ in the number of Hispanic residents (University of South Carolina, 2008 and Bryan, 2010).

While these figures indicate a tremendous population growth in this sector of the population, they only include legal residents within the state who are allowed to participate in the U.S. Census studies. As a result, the actual population is estimated to include an additional 45,000-75,000 others, who are undocumented (Young, 2005).

Table10. Hispanic Population Growth in South Carolina

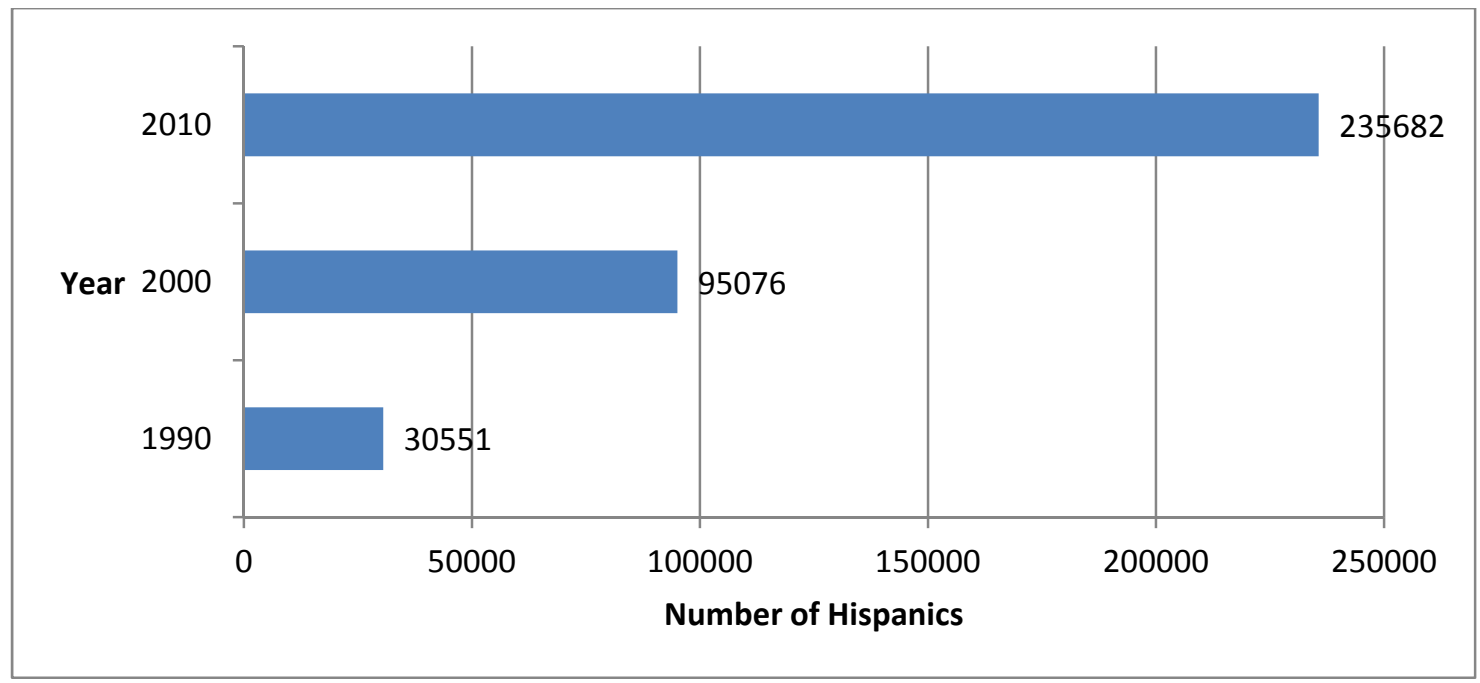

(Source: www.factfinder2.census.gov)

Since 1997, the Hispanic population of the state has more than tripled, with the majority of the growth taking place since 2000. Since the year 2000, the number of Hispanics in South Carolina has grown from 30,551 to 95, 076 (Carolinas AGC, 2007, p. 1). This represents a total growth of $211 \%$. However, some estimates place South 
Carolina's Hispanic population closer to 500,000, with $75 \%$ of Hispanics in the state arriving from Mexico. The large disparity in the population estimate is due to the fact that many Hispanics are in the state illegally (Tornoe, 2007, pp.1-2). This is a marked increase in the population of one specific ethnic group that once, "exercised little, if any influence on the state's political or economic culture” (SC Hispanic Outreach, 2010).

According to Elaine Lacy, Director of the University of South Carolina’s Consortium for Latino Immigration Studies, the exponential increase of the Hispanic population in the past 13 years is a direct result of Mexico’s economic crisis during the 1990’s (Tornoe, 2007, p. 1). Prior to 2000, most Hispanics came to the southern states only for seasonal agricultural work. After the year 2000, however, many Hispanics found permanent employment in South Carolina in the areas of construction, landscaping, meatpacking, auto-assembly, food-processing, various service industries, and landscaping. As a result, many immigrants began to leave Mexico and arrive directly to South Carolina (Tornoe, 2007, p. 2). Furthermore, many also began to bring and settle families rather than traveling alone following seasonal jobs, thereby further increasing the state's Hispanic population.

\section{Beaufort County, South Carolina}

From 1990 until 2010, the Hispanic population in Beaufort County increased from approximately 1,300 to 12,000 , an increase of $923 \%$. The majority of that growth took place between 2002 and 2005 (1990, 2005 Annual Reports). As in other parts of the state, many Hispanics settled in Beaufort due to jobs in construction, hospitality, and tourism. As a result, Beaufort County currently houses the second largest Hispanic population in the state of South Carolina. 
Table 11. Hispanic Population Growth in Beaufort County, South Carolina

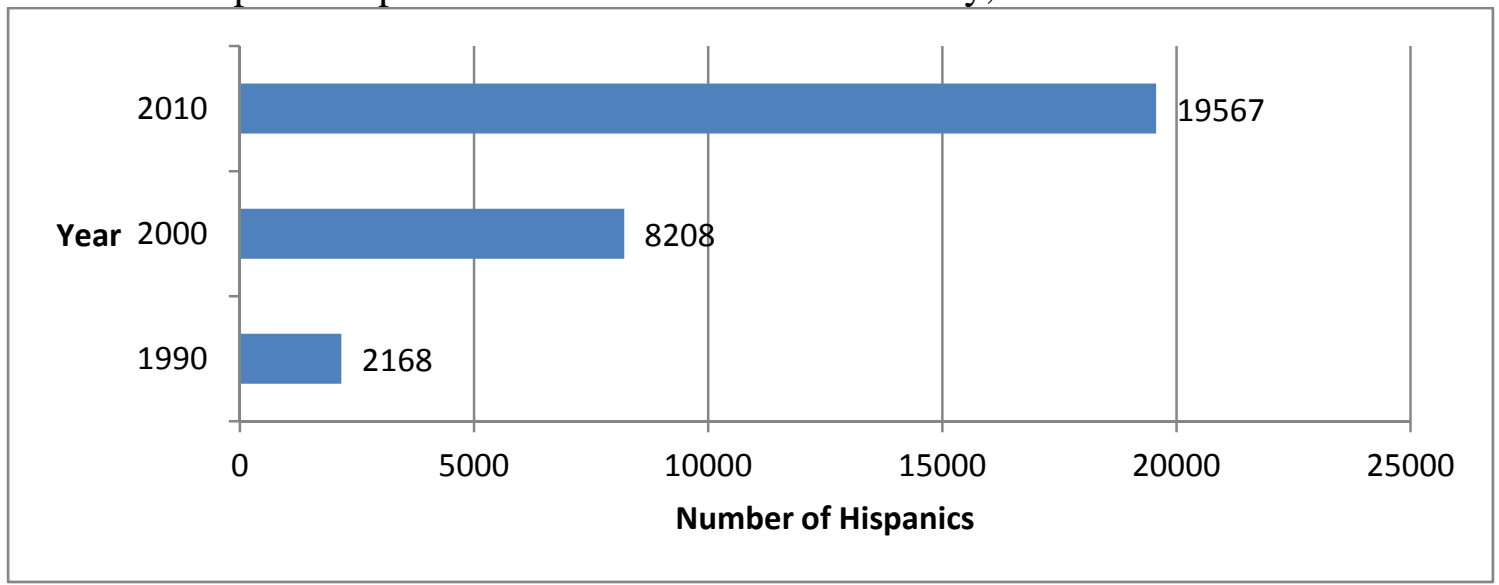

(Source: Beaufort County Annual Reports, 1990, 2000, and 2010)

\section{Hispanic population boom in schools}

\section{The United States}

Since not only bread-winners were arriving into the state, families brought their children. Naturally, the exponential growth of Hispanics is reflected not only in the general population of the country-but also in schools. Hispanic/Latino students are also the largest and fastest growing minority group among school-age children in the United States (Smith-Adcock, et. al, 2004, p. 1). Current estimates say that in 2012, 5.3 million school-age children in the United States were classified as LEP (Limited English Proficiency), and that number continues to grow (http://www.migrationinformation.org). 
Table 12. States’ ELL Population Growth from 1995-2005 and 2005-2012

\begin{tabular}{|l|l|l|l|l|}
\hline State & $\begin{array}{l}\text { \# of ELLS in } \\
\mathbf{2 0 0 5}\end{array}$ & $\begin{array}{l}\text { \% of Growth } \\
\text { from 1995 }\end{array}$ & $\begin{array}{l}\text { \# of ELLs } \\
\text { in } \\
\mathbf{2 0 1 2}\end{array}$ & $\begin{array}{l}\text { \% of } \\
\text { Growth } \\
\text { from 2005 }\end{array}$ \\
\hline South Carolina & 15,396 & $714.2 \%$ & 38,553 & $150.5 \%$ \\
\hline Kentucky & 11,181 & $417.4 \%$ & 18,579 & $66.2 \%$ \\
\hline Indiana & 31,956 & $407.8 \%$ & 51,240 & $60.4 \%$ \\
\hline North Carolina & 70,288 & $371.7 \%$ & 105,056 & $49.5 \%$ \\
\hline Tennessee & 19,355 & $369.9 \%$ & 32,570 & $68.3 \%$ \\
\hline Alabama & 15,295 & $336.8 \%$ & 19,468 & $27.3 \%$ \\
\hline Nebraska & 16,124 & $301.4 \%$ & 20,304 & $25.9 \%$ \\
\hline Arkansas & 17,384 & $294.6 \%$ & 32,814 & $88.8 \%$ \\
\hline Georgia & 50,381 & $291.6 \%$ & 90,595 & $79.8 \%$ \\
\hline Colorado & 90,391 & $237.7 \%$ & 112,529 & $24.5 \%$ \\
\hline Nevada & 72,117 & $208.3 \%$ & 79,347 & $10.0 \%$ \\
\hline New Hampshire & 3,235 & $198.4 \%$ & 4,495 & $38.9 \%$ \\
\hline Virginia & 67,933 & $196.1 \%$ & 97,837 & $44.0 \%$ \\
\hline Delaware & 5,094 & $183.2 \%$ & 7,007 & $37.6 \%$ \\
\hline Missouri & 15,403 & $183.0 \%$ & 24,891 & $61.6 \%$ \\
\hline Utah & 56,319 & $163.7 \%$ & 38,401 & $-31.8 \%$ \\
\hline Minnesota & 56,829 & $161.4 \%$ & 70,225 & $23.6 \%$ \\
\hline Iowa & 14,421 & $148.3 \%$ & 22,425 & $55.5 \%$ \\
\hline Oregon & 59,908 & $133.1 \%$ & 58,580 & $-2.2 \%$ \\
\hline Kansas & 23,512 & $131.7 \%$ & 47,040 & $100.1 \%$ \\
\hline Ohio & 25,518 & $108.4 \%$ & 42,824 & $67.8 \%$ \\
\hline Wyoming & 3,742 & $101.9 \%$ & 2,752 & $-26.4 \%$ \\
\hline Pennsylvania & 39,847 & $100.3 \%$ & 49,465 & $24.1 \%$ \\
\hline Sourc: Payan & & \\
\hline
\end{tabular}

(Source: Payán and Nettles, p. 5 and www.eddataexpress.gov)

\section{The South}

In 1990, the school district of Springdale, Arkansas had just slightly under 8,000 students and English as a second language (ESL) students were virtually non-existent. Those numbers changed dramatically from 1990 to 2005 when the thriving job market in companies such as Tyson Foods and Wal-Mart attracted thousands of immigrants from the Marshall Islands and Mexico. During the fall of 2008, the ESL population alone of Springdale, Arkansas schools was 7,000 students, or $40 \%$ of the total school district student population (Maxwell, 2009). 
Noting these bursts of demographic change, Maxwell (2009) reported that these types of dramatic increases in areas "that had little recent experience with new immigrant and the social and educational needs” (p.1) left schools scrambling to meet the needs of this new sector of the population. He further stated

that sweeping shift in demographic patterns has strained that capacity of school districts, and even state departments of education, to develop and pay for instructional programs to teach children who are still learning English. In many cases, educators in such communities have relied on a piecemeal, ad hoc approach (p.1).

Table 13. Number of ELLs in New Settlement States of the South in 2012

\begin{tabular}{|l|l|}
\hline State & Number of ELLs in 2012 \\
\hline Alabama & 19,468 \\
\hline Arkansas & 32,814 \\
\hline Georgia & 90,595 \\
\hline North Carolina & 105,056 \\
\hline South Carolina & 38,553 \\
\hline Tennessee & 32,570 \\
\hline
\end{tabular}

(Source: www.eddataexpress.gov)

\section{South Carolina}

In May 2005, South Carolina and its 86 different school districts reported approximately 16,100 ELL students in the state. Of those ELL students, $75 \%-80 \%$ are Hispanic and these numbers represent a 521\% growth in number of ELLs since 1993. As reported in 2012, the current number of ELLs in South Carolina has reached 38,553. This indicates grown an additional growth 139.45\% in the ELL population since 2005.

\section{Beaufort County, South Carolina}

From 2002-2010, the ESL student population in the county increased more than $100 \%$. As a result, the Beaufort County school system currently has the second largest number of English language learner (ELL) students in the state. During the 2010-2011 academic year in Beaufort County, Hispanic students made up approximately 20 percent 
of the school system's total enrollment. In Hilton Head, the Beaufort County golf and boating resort community previously mentioned, Hispanic students constitute 30 percent of the total student population. Furthermore, there are schools in the district where more than 50 percent of the total student enrollment are English Language Learners (ELLs) (Staff Reports, 2010).

Table 14. Growth of Hispanic Students in Beaufort County Schools

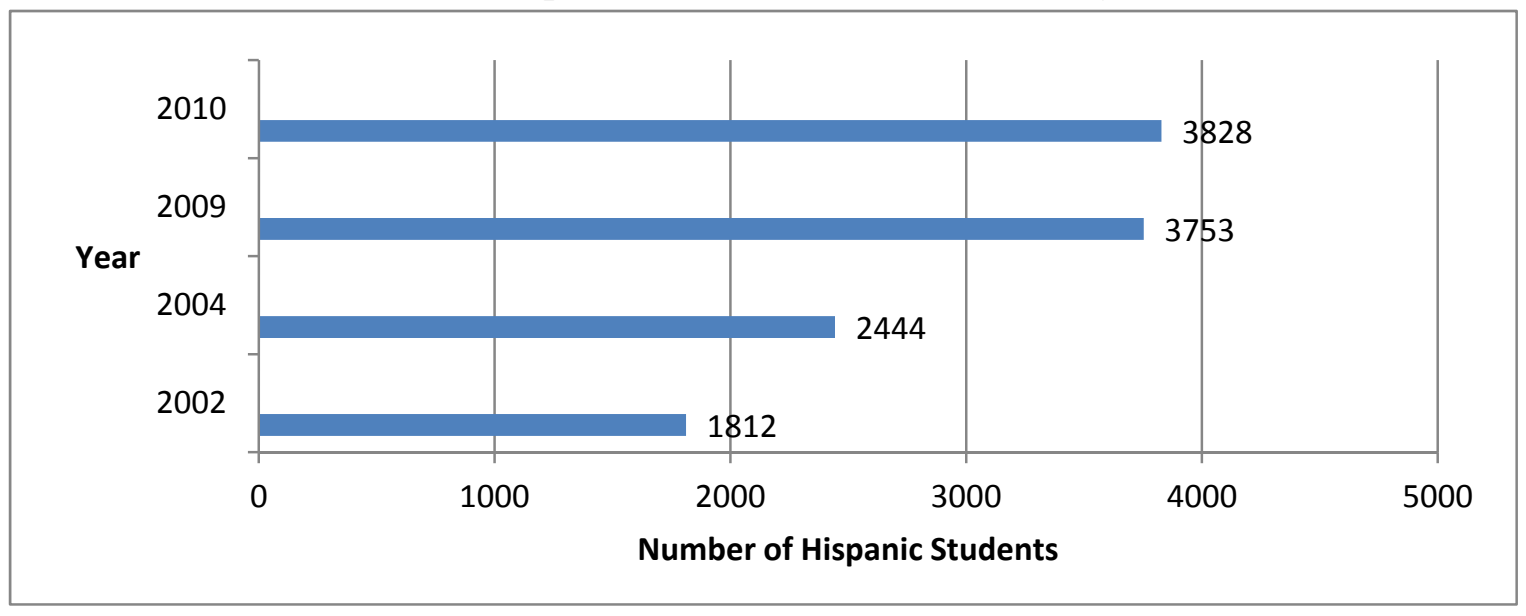

(Source: Annual Staff Reports, 2002, 2004, 2009, 2010)

\section{Conceptual Framework}

Introduction

The conceptual framework is a model based on what is needed for student achievement based on federal law, historical, and current trends in education. The right side of the model focuses on ELLs while the left side of the model is for mainstreamed students. This model represents how the education both ELLs and mainstreamed students receive has been influenced by separate events while trying to meet the common goal of student achievement. 
Figure 4. Conceptual Framework for ELLs and Parallel Historical Structure for Mainstream Students

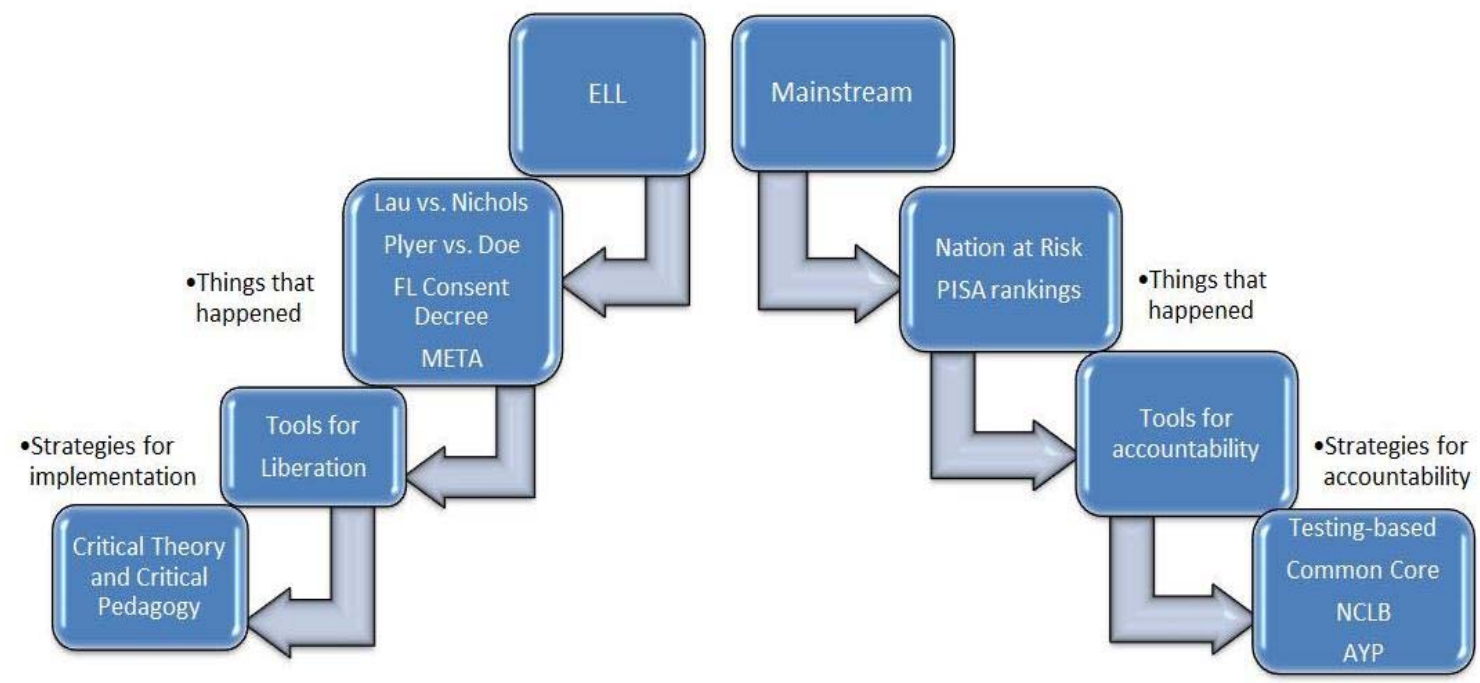

\section{Policies affecting ELLs}

Figure 5. ELL side of the Conceptual Framework Underlying Representation.

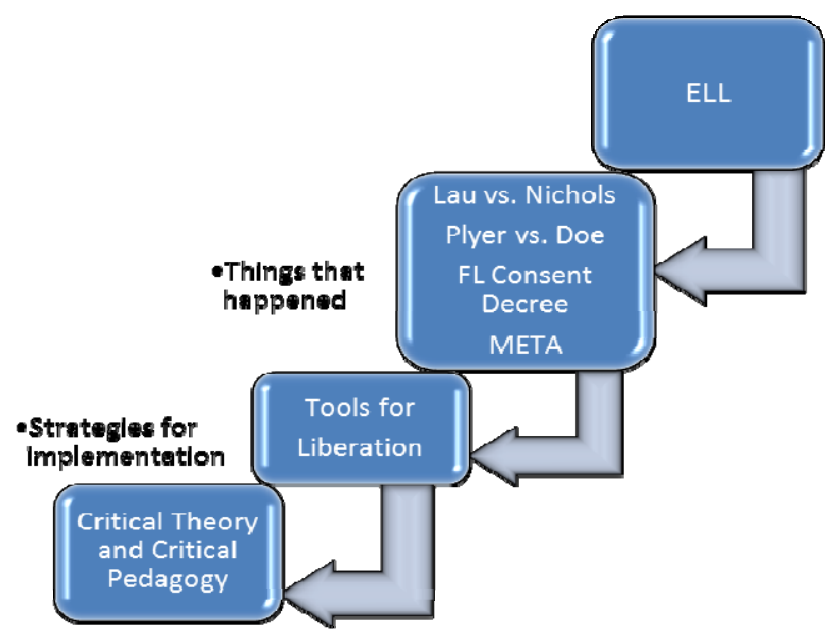




\section{National Policy}

Before the early 1970’s, language education for immigrant students was virtually non-existent. Ellen Curtin (2005) states that language education policy for immigrant students required them to "assimilate as quickly as possible with no language support or transitional period in their own language” (p.1). This policy continued until 1974 when the U.S. Supreme Court handed down a decision in the landmark education case of Lau vs. Nichols. The Supreme Court forever changed how language students are educated by deciding in the favor of 1,800 language minority students from San Francisco who felt they were not being properly educated in English-only classrooms. In the decision, Justice William O. Douglas wrote: “There is no equality of treatment merely by providing students with the same facilities, textbooks, teachers, and curriculum; for students who do not understand English are effectively foreclosed from any meaningful education” (Lessow-Hurley, 2000, p. 129). In spite of providing all students with equal facilities and opportunities for education, the Supreme Court still found the San Francisco school district was violating the students' civil rights by not providing an education that was meaningful and comprehensible to the language minority students. This decision stated that all children must receive equal education, regardless of their ability or inability to speak English (Lessow-Hurley, 2000). While the Supreme Court did not offer any specific remedies to the problem, this decision and the legislation that followed still affect how LEP students are educated 39 years later.

Another landmark Supreme Court decision that still affects ELLs in the United States was Plyler vs. Doe in 1982. In 1975, the state of Texas passed a law that allowed the government to withhold funds from schools educating illegal immigrants, and it 
allowed schools to deny entry to the children of undocumented immigrants (www.casebriefs.com, 2013). In 1982, the Supreme Court ruled against Texas legislation by deciding that states may not deny the children of illegal immigrants access to a free public education.

Another piece of instrumental legislation concerning ESL student achievement, and born from the Lau vs. Nichols (1974) decision, was The Florida Consent Decree of 1990. In this case, the United States District court of Florida awarded the courts the authority to enforce an agreement between a coalition of eight multicultural groups and the Florida State Board of Education. The coalition of eight civil rights and educational groups, the plaintiffs, were represented by Multicultural Education, Training, and Advocacy, Inc. (META). The result of the case led to an agreement on six different issues concerning those students whose first language is not English: 1) identification and assessment, 2) equal access to appropriate programming, 3) equal access to appropriate categorical and other programming for LEP students, 4) personnel, 5) monitoring, and 6) outcome measures (www.fldoe.org).

\section{Critical Theory and Tools for Liberation}

Founded in the 1920's by researchers at the Institute of Social Research in Frankfurt, Germany, critical theorists analyze power relationships within society. According to Kincheloe and McLaren (2000) some of the underlying beliefs for this school of thought include that certain groups in society are privileged over others and that oppression has many faces including the public school system and governmental institutes (Gall, Gall, and Borg, 2003, pp. 496-497). Additionally, critical theorists believe that the current educational system functions to merely reproduce a person's 
current class in society under the concept of hegemony (Bourdieu, 1984). Gall, Gall, and Borg (2003) define hegemony as "the maintenance of domination of subordinate groups by privileged groups” (p. 497). However, critical theory does not stop with the belief that society and educational systems are structured only to replicate a class system in which mobility does not exist. Horkheimer (1982) continues to say that the purpose of critical theory is "to liberate human beings from the circumstances that enslave them" (p. 244). Therefore, one's position in society is not seen as fixed in an eternal battle of the oppressors vs. the oppressed. However, not all entities of U.S. society are pleased to see the liberation of the classes. Anderson and Irvine (1993) state that while critical theorists believe that our current society is built on conflicts of interests and unfair social relations, the sole purpose of many factions of U.S. society is to reinforce their dominant role (p.82). According to Giroux (2006), Evangelical Christians and the administration of President George W. Bush have tried to destroy critical education's focus on creating engaged citizens through, "attempts to standardize the curricula, privatize public schooling, and use the language of business as a model for running schools” (p. 29). Giroux (2006) continues to say that under the anti-critical educational approach "schooling is reduced to training, rote learning, and, with regard to poor minorities in poverty stricken neighborhoods, becomes a form of warehousing” (p. 30). Finally, Kincheloe (2008) views the standardization of education as turning schools into the corporate order's machine for sorting students (p. 33).

\section{Critical literacy and critical pedagogy: the tools of liberation}

While critical theorists refer to schools as 'sorting machines' and 'warehouses for the poor,' they also recognize the dual role they play. McLaren and Tadeu da Silva 
(1993) state "the most important sites for resisting enslavement to machineries of servitude are the schools” (p. 83). Freire (1970) states that a person can avoid becoming disenfranchised or marginalized through "liberatory intervention” in education (p. 7). Kincheloe (2008) writes that "if enough people think in new ways, social and pedagogical transformation is inevitable” (p.32). Given the optimistic attitude of critical theorists concerning schools, the question then becomes about what tools schools can utilize to bring social change and liberation to those they had previously marginalized. The answer is critical literacy and critical pedagogy.

\section{Critical literacy}

Anderson and Irvine (1993) define critical literacy as "learning to read and write as part of the process of becoming conscious of one's experience as historically constructed within specific power relations” (p. 82). They continue to say that the goal of this learning is “to challenge these unequal power relations" (p. 82). Giroux (1993) states that the purpose of literacy must be redefined so that

subordinate groups learn the knowledge and skills necessary for self and social empowerment, that is, to live in a society in which they have the opportunity to govern and shape history rather than be consigned to its margins. Literacy in this sense is not just a skill or knowledge, but an emerging act of consciousness and resistance (p. 367).

Giroux (1993) supports such stating that changing how schools think about and define literacy is necessary "in order to address the needs of those groups who traditionally have been excluded within the dominant discourse of schooling” (p.367). In order for this to liberation to occur, the literature itself must focus on justice, freedom, and equality rather than reinforcing "hierarchies, oppression, and exploitation” (Giroux, 1993, p.368). Once 
this shift in focus takes place, literacy becomes "emancipatory" and "is a language in which one speaks with rather than for Others” (Giroux, 1993, p.369).

\section{Critical Pedagogy}

In the process of trying to liberate and emancipate Others through education, critical pedagogy focuses on the teachers’ role and approach to knowledge. Kincheloe (2008) states that "pedagogy believes that nothing is impossible when we work in solidarity and with love, respect, and justice as our guiding lights” (p. 9). He continues to state that the purpose and goal of critical pedagogy is "to help teacher educators and teachers reconstruct their work so it facilitates the empowerment to all students” (p. 9).

Those who practice critical pedagogy must have a deep understanding of students and the types of knowledge they bring to the classroom. Kincheloe (2008) states that “critical pedagogy has to appreciate a variety of perspective on the way knowledge is produced and deployed” (p.10). Additionally, “critical teachers maintain that students should study the world around them, in the process learning who they are and what has shaped them” (Kincheloe, 2008, p.11). Finally, Kincheloe (2008) says that the role of guiding students through their process of self-discovery also requires “critical scholars (to) work hard to gain insight from various cultures and knowledge producers” (p.10).

In the case of the ELL students in Beaufort County, South Carolina, the importance and role of language also comes into question. The ELLs in the school system represent not only different countries and cultures, but they are also confronted with the issue of learning a new language. Those who are native-English speakers are placed in a position of power and dominance over those who are not native-English speakers. Just as schools play dual roles as tools of domination and/or empowerment, critical theorists also 
believe that language has the same duality. Freire views language as a source to “ reproduce dominant forms of power relationships", it also has the potential “for dismantling the oppressive power structures of the social order, and also for articulating a more transformative and liberating vision of the future” (McLaren and Leonard, 1993, p. 53). In order to obtain this transformation and liberation, practitioners of critical pedagogy must establish a form of critical literacy in the classroom "for actively contesting the power arrangements that structure the politics of the everyday” (McLaren and Leonard, 1993, p. 57).

One of the final charges for those who practice critical pedagogy is to manipulate the same systems and people who oppress in order to serve as "a form of critique and also a referent for hope” (McLaren and Leonard, 1993, p. 69). McLaren and Leonard (1993) also state

resistance must not only consist of the struggle against oppression but through oppression by means of dialogical engagement with and transformation of oppressive social relations (p. 82)

Therefore, alliances in schools must be forged between those in power and the oppressed in order to have a transformative and emancipatory educational experience.

When looking at the recent influx of Hispanics into South Carolina and the Beaufort County School System, the question of assimilation to a new culture and a new language is raised. Park (1950) stated that there is a universal process of assimilation that all immigrants face while integrating into a new culture (Alvarez, 2000). When a new group comes into contact with the dominating culture "conditions of poverty and the lack of skills in the dominant language force immigrant groups into a state of social isolation and marginality” (Alvarez, 2000, p. 48). Portes (1981) and Portes and Bach (1985) also 
describe immigrants' adaptation process as occurring in one of three sectors based on their socioeconomic status and job skills. The primary sector is composed of immigrants with special job skills or professions that are brought to the country only because of those skills. The secondary sector is composed of those immigrants who come to work, legally or illegally, for short amounts of time. The final sector is an enclave. An enclave is an area "built by a group of immigrants who concentrate in a particular geographic location" (Alvarez, 2000, p.72). Additionally, an enclave creates a shell which "permits members to carry out most activities within its borders, with a limited degree of contact with the host culture” (Alvarez, 2000, p.72).

The idea of marginalization is reinforced by the critical theory which "assumes that society is structured by class and status, as well as by race, ethnicity, gender, and sexual orientation to maintain the oppression of the marginalized groups" (Marshall, 1999, p. 6). Despite meeting all of the circumstances necessary for the formation of an enclave and the marginalization of ELLs in Beaufort Country, the language minority students in the school system have performed exceeding well on standardized tests. Therefore, this group of students has not followed the pattern for how society is structured according to the critical theorists. The ELLs of Beaufort County are succeeding in school and attaining Freire’s 'liberatory intervention' while ELLs in other parts of the United States are experiencing mass failures.

\section{Policies Affecting Mainstream Students}

\section{Mainstream Policies}

When analyzing the right side of the conceptual framework underlying representation, the federal laws, policies, historical and current trends affecting mainstream students are 
presented. Some of the policies and federal laws such as No Child Left Behind (NCLB) and common core influence how both ELLs and mainstream students are taught.

Figure 6.Historical Trends Affecting Mainstream Student Education

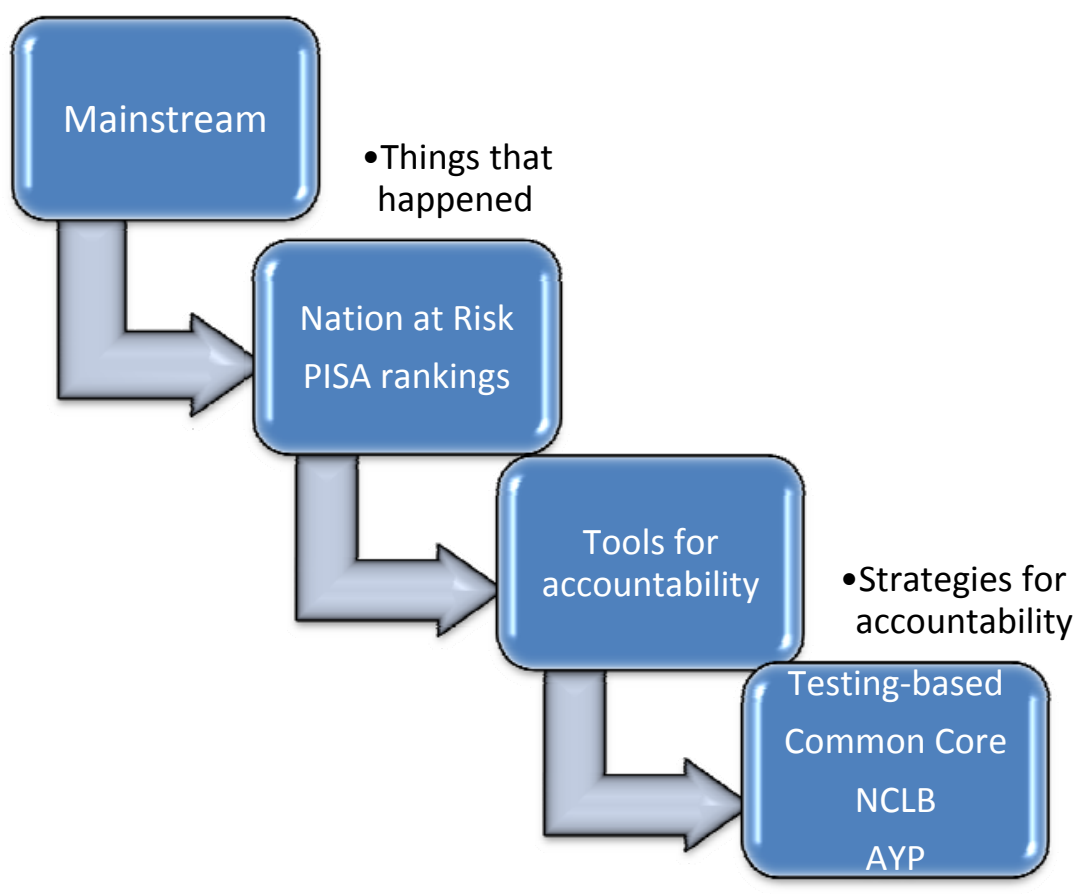

\section{National Policy}

\section{Nation at Risk}

In 1983, the results of an eighteen month study by the National Commission on Excellence in Education began with the line "Our Nation is at risk" (Nation at Risk, p. 1). The research conducted by National Commission on Excellence in Education focused on secondary school curricula and found that the curricula were no longer unified by a central purpose (Scherer, n.d.). The poor state of U.S. schools as outlined in this report instilled the fear of no longer being competitive with other countries in educational and job markets. The impending result would cause the United States to lose its competitive 
edge in the world's market economy. In order to avoid this situation, the commission outlined five specific changes for curricula in U.S. schools:

1) Four years of English;

2) Three years year of math;

3) Three years of science;

4) Three years of social studies;

5) Half a year of computer science.

In addition to the changes in basic curricula, this report also established the standards that should be accomplished by these changes. These standards stated "the teaching of English in high school should equip graduates to:

(a) comprehend, interpret, evaluate, and use what they read;

(b) write well-organized, effective papers;

(c) listen effectively and discuss ideas intelligently; and

(d) know our literary heritage and how it enhances imagination and ethical understanding, and how it relates to the customs, ideas, and values of today's life and culture" (Nation at Risk, 1983).

"The teaching of mathematics in high school should equip graduates to:

(a) understand geometric and algebraic concepts;

(b) understand elementary probability and statistics;

(c) apply mathematics in everyday situations; and

(d) estimate, approximate, measure, and test the accuracy of their calculations" (Sherer, n.d. ; Nation at Risk, 1983).

Finally, the National Commission on Excellence in Education defined excellence in education as "a school or college that sets high expectations and goals for all learners, 
then tries in every way possible to help students reach them" (Nation at Risk, 1983). In order to achieve the goal of obtaining excellence in education, the National Commission recommended that teaching, teacher education, and education standards also needed to be reformed. It was this report that helped pave the foundation for standardized testing in schools, raising teacher salaries to retain and attract well-qualified teachers, and instituting merit pay for teachers (Scherer, n.d.).

\section{International Rankings and Accountability}

PISA

The Programme for International Student Assessment (PISA) is an assessment given every three years to 15 year olds from around the world in order to evaluate their various educational systems. The purpose of PISA is to help "countries and economies participating in successive surveys can compare their students' performance over time and assess the impact of education policy decisions” (www.oecd.org). PISA assessments are different because they are not directly derived from the school curriculum standards. The tests are designed to measure to what extent students can apply their knowledge to real-life situations and be equipped for full participation in society. Since the year 2000, the students from randomly selected schools around the globe take tests in the key subjects: reading, mathematics and science.

In 2012, sixty-five different countries that constitute $90 \%$ of the world's economy participated in the PISA assessment. Recent data from the Organisation for Economic Cooperation and Development (OECD), the intergovernmental agency of industrialized countries that coordinates PISA assessments, reveal that American student achievement has stagnated while achievement in Asian countries is on the rise 
(http://nces.ed.gov/surveys/pisa/ ; http://asiasociety.org). This data and these trends are significant to the participating countries for several reasons. The OECD Directorate for Education has found that the best indicator for the future economic health of a country is student achievement in science and math. In other words, nations or cities with schools performing poorly in science and math can expect to have poorly performing economies; conversely, countries and cities with schools that perform well in science and math can expect to have healthy economies in the future (http://asiasociety.org). Other uses for PISA data include:

1) To measure whether school systems are adequately preparing students for the workforce;

2) To reveal common trends and patterns among well performing schools;

3) To measure the success of programs and reforms schools have implemented;

4) To provide international benchmarks among schools to measure best practices;

5) To drive positive reform in worldwide schools (http://asiasociety.org).

\section{No Child Left Behind}

No Child Left Behind (NCLB) was an educational law passed on January 8, 2002 under the administration of President George W. Bush. The purposes of NCLB were to "ensure accountability as well as increased federal support for education” so that all students could partake in an educational experience that is "inclusive, responsive, and fair” (www.ed.gov/nclb). No Child Left Behind was based upon 8 principles that included: 
1) Improving the academic achievement of the economically disadvantaged

2) Preparing, training, and recruiting highly qualified teachers and principles

3) Language instruction for limited English proficient and immigrant students

4) Giving parents choices and creating innovative education programs

5) Making the education system accountable

6) Making the system responsive to local needs

7) Helping all children learn to read

8) Helping children with disabilities (www.ed.gov/nclb).

No Child Left Behind, ELLs, and Annual Yearly Progress

With respect to NCLB and ELLs, this law requires that

each state create an accountability plan that includes implementation of academic and performance standards for all students. States are also required to show that ELLs are progressing in their proficiency of the English language by meeting annual measurable achievement objectives (NCLB, 3122(b)(2001)).

The increased focus on the achievement of ELLs places the responsibility on each individual state for improvements in instruction and students' achievement. The progress made by students is measured each year by standardized tests and summarized in a report called Adequate Yearly Progress (AYP). Each state designs its own standards and goals for AYP based on guidelines provided by the federal government. If a school fails to meet the goals established for AYP, it could affect the funding received from the federal government (California Department of Education, 2012). 


\section{Student Achievement}

\section{Adequate Yearly Progress (AYP)}

When looking at the elements necessary for making AYP goals, schools are

allowed some flexibility in determining what their goals will be. However, NCLB

dictates that the process of meeting those goals must include each of the following requisites:

1) State tests must be the primary factor in the state's measure of AYP, but the use of at least one other academic indicator of school performance is required, and additional indicators are permitted

2) For secondary schools, the other academic indicator must be the high school graduation rate

3) States must set a baseline for measuring students' performance toward the goal of 100 percent proficiency by spring 2014. The baseline is based on data from the 2001-02 school year

4) States must also create benchmarks for how students will progress each year to meet the goal of 100 percent proficiency by spring 2014

5) A state's AYP must include separate measures for both reading/language arts and math. In addition, the measures must apply not only to students on average, but also to students in subgroups, including economically disadvantaged students, students with disabilities, English-language learners, African-American students, Asian-American students, Caucasian students, Hispanic students, and Native American students

6) To make AYP, at least 95 percent of students in each of the subgroups, as well as 95 percent of students in a school as a whole, must take the state tests, and each subgroup of students must meet or exceed the measurable annual objectives set by the state for each year "(Editorial Projects in Education, pp.1-2).

The number of schools failing to meet AYP requirements has increased each year since the implementation of NCLB. When looking at recent results, $28 \%$ of U.S. schools failed to make AYP in 2007, and that number had increased to 38\% by 2011. The U.S. 
Secretary of Education, Arne Duncan, feared that $82 \%$ of schools could be failing by the end of 2011 if the current measures of AYP were not rewritten. Although the numbers for 2010-2011 school year were not as high as predicted by Secretary Duncan, a record high $48 \%$ of schools did fail to meet AYP goals for the year (Editorial Projects in Education; Usher, Alexandra).

While the requirement to provide adequate education for all children is federally mandated, the process of how to accomplish this goal is legislated by each state. As a result, each state can determine how long ESL students receive "sheltered" instruction. While the amount of time required for a student to become proficient in a language is highly debated, some states use as little as 3 years as a benchmark. In the state of Texas, all ESL students are required to take the state standardized test, the Texas Assessment of Knowledge and Skills (TAKS), at the same level as native English speakers after only three years of language instruction (Curtin, 2005). This practice is highly looked down upon by second language acquisition theorists, like Cummins (1996), who find five to eight years to be more realistic time frames for acquiring academic language. Theorists also believe that five to eight years allows time to compensate for other variables such as age, cognitive ability to learn a language, the prior education, and the language of a student's home country (Curtin, 2005, p.1). While many language theorists criticize Texas and requiring ESL students to take state standardized test in 3 years, ESL students in South Carolina take the PACT (Palmetto Achievement Challenge Test) after 1 year of English instruction. However, their scores are not included in AYP reports until they have received 3 years of ESOL instruction. 


\section{Common Core}

No Child Left Behind is currently being replaced as the guiding educational policy in many states by the Common Core State Standards. The common core as it is usually referred to have been in the works since 2008 and specifies what students throughout the United States should be able to by each grade level. This initiative was started by former Arizona Governor Janet Napolitano and sought to correct what some believed were 2 major oversights in the NCLB educational law: allowing each state to choose its educational standards and the assessments used to measure student achievement of those standards and improving science and math education as well as workforce readiness (Bidwell, 2014). According to Dane Linn, 2006-2007 Chair of the National Governor’s Association, some states measure student achievement on exceptionally low state-generated standards. As a result, many students were shocked when they graduated from school and found themselves in remedial English and math classes when they began their college studies (Bidwell, 2014). However, the common core also has its critics among parents, politicians, and educators alike. Many opponents find this new educational initiative to be a "sneaky attack on states' rights to control local education” and a loss of state autonomy in the educational needs of students (Bidwell, 2014).

\section{Candidates for Examination with the Conceptual Framework}

\section{Policy}

When analyzing the components of the conceptual framework, it is important to note that both the ELL side and the mainstream side, while shaped by different historical events and current trends in education, share the common goal of obtaining student 
achievement and success. However, it is important to note that ELLs are affected not only by the policies and laws established to ensure they are properly educated, but they are also governed by same strategies and tools for accountability as mainstream students. As a result, both sides of the conceptual framework are necessary, are overlapped, and are influenced by the same entities in order to achieve ELL student 'success' as defined by educational stakeholders.

Figure 7. Application of Policy within the Conceptual Framework and Historical Trends

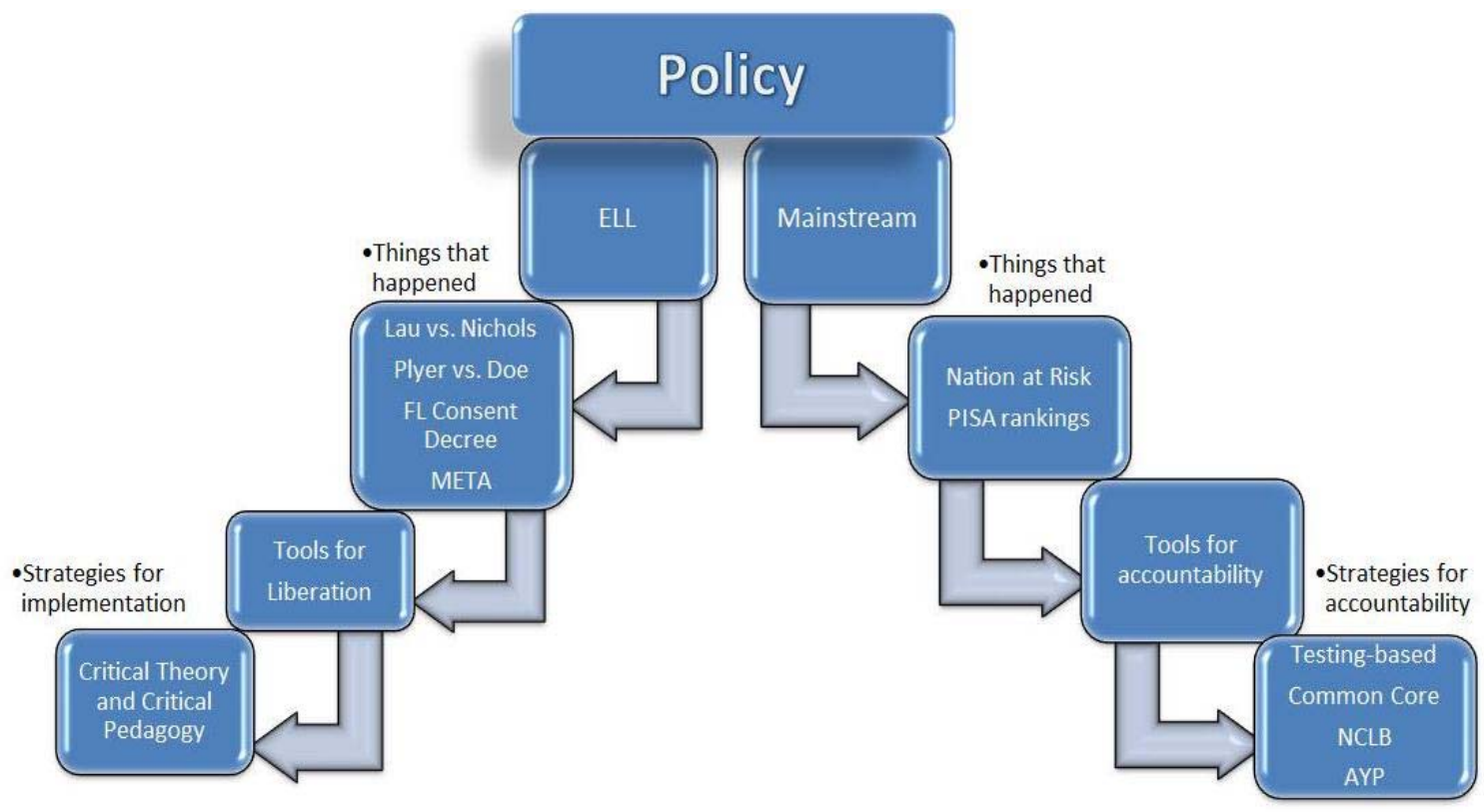

\section{Leadership}

Bennis and Nunus (1997) conducted studies that focused on the role of leadership in the field of education, a field which is constantly in flux with new theories, learning approaches, strategies, and increased demands upon teachers. They continue to say that the constant changes create a work environment for educators that is impacted by three factors: “commitment, complexity, and credibility” (Murray, 2009, p. 14). With respect to commitment, many teachers feel the level of respect for their job as well as the lack of 
long-term contracts has diminished the value of their work in society. As a result, many teachers feel that "they will not commit to an organization that will not commit to them" (Murray, 2009, p. 15). The complexity of the job has also changed due to the many tasks educators are required to fulfill in curricular development, assessment, counseling, and accountability measures in addition to teaching the standards that must be met. Credibility as an educator has been affected by the trends for accountability and assessment which has turned the field of education into "a customer service oriented" business where the value of a teacher's work is based on student performance on standardized tests (Murray, 2009, p. 15).

Constant shifts in the field of education, teacher attitude, and the value placed on teachers present educational leadership with the difficult issue of how to best complete their duties. Bennis and Nanus (1997) state that there are four requirements educational leaders must employ in order to successfully lead teachers in the type of environment that currently exists in education. Those four strategies are:

1) attention through vision;

2) meaning through communication;

3) trust through positioning;

4) the development of self (Murray, 2009, p. 15).

Bennis and Nunus (1997) continue to state that the relationship between leaders and their teachers must be symbiotic and not dictatorial. In order to help the teachers and their feedback to feel valued in schools,

Leaders can provide the proper setting for innovation learning by designing open organizations in which participation and anticipation work together to extend the time horizons of decision-making, broaden their perspective, allow the sharing of 
assumptions and values and facilitate the development and use of new approaches (Murray, 2007, p. 15).

Therefore, "the development of new approaches" that would result from teachers, ESL and mainstream leadership working together would accomplish Kincheloe’s (2008) “pedagogical transformation” that takes place when "enough people think in new ways" (Murray,1997, p. 15; Kincheloe, p. 32).

Figure 8.Application of Leadership within the Conceptual Framework and Historical Trends

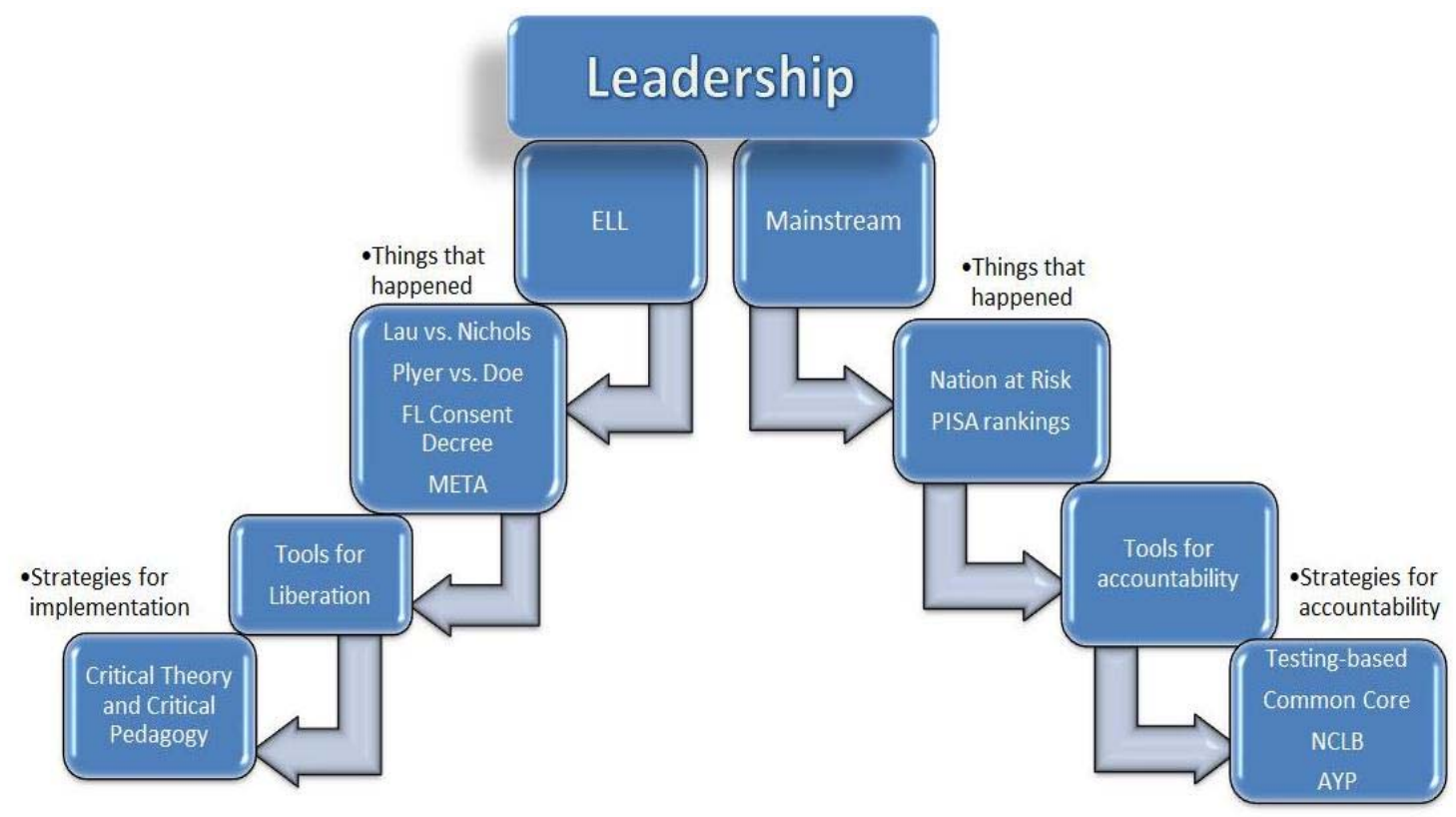

\section{Teacher training}

Under the accountability measures mandated by NCLB and Common Core, mainstream teachers are now required to help ELL students learn academic content while implementing and improving their English language skills. Given these dual functions of classroom teachers and the growing number of ELLs in U.S classrooms, educators must know which teaching methodologies and strategies to utilize to accommodate ELLs more successfully in classroom settings. Whether this process begins in teacher education 
programs or professional development after graduating, educators must know how ELLs learn best. In a 1997 study, Malloy found that, "ESL and culturally diverse students generally have a global orientation to learning and are receptive to learning that is relational and holistic and employs thematic approaches” (Curtin, 2005, p.2). Therefore, ESL student learns better when content across the subject areas is related by a common theme or topic. Additionally, student benefit when they are taught with approaches and methodologies that utilize the various language skills of listening, reading, writing, speaking, and employ visual elements and components as well.

Educators must also give extra consideration to how lessons are delivered when working with ELLs. Presmeg (1989) advocated the used of "visual and tactile modes" with language minority students (Curtin, 2005, p. 2). Hatfield, et al (1997) also found that the use of technology in the classroom supported the learning style of ESL students. When asking questions, teachers must wait and give extra time for answers when working with ELLs (Callahan, 1994). Finally, Thompson (2000) found that ELLs respond better to certain types of activities in the classroom. The most helpful instructional strategies included "literature based activities, oral practice, individual help, peer interaction, games, and the use of realia (real objects)” (Curtin, 2005 p. 2). 
Figure 9. Application of Teacher Training with the Conceptual Framework and Historical Trends

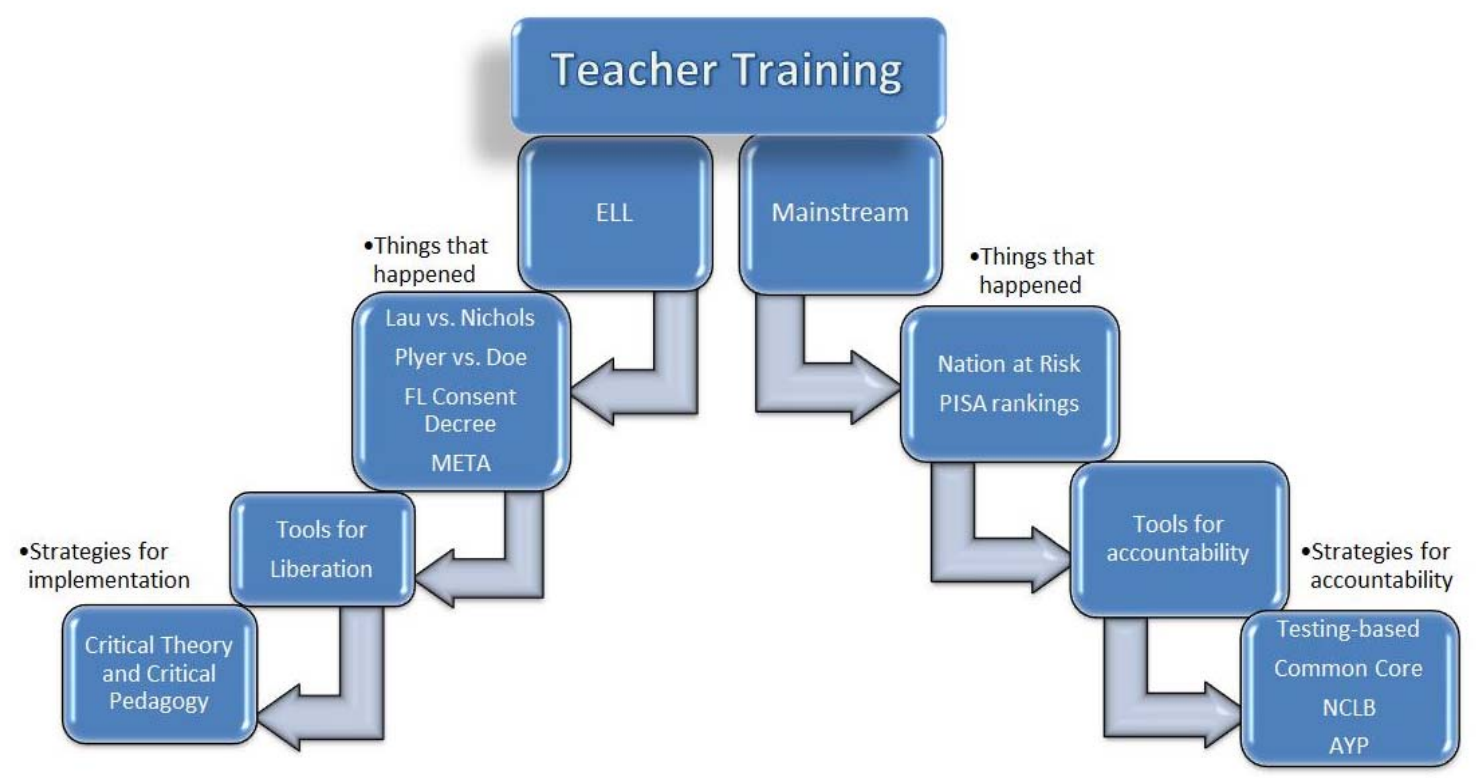

Issues ELLs face in Mainstream Classes

There are other widespread issues ELL student confront in U.S. classrooms. Not only are students affected by a lack of qualified ESL teachers, but an overall lack of teachers nationwide. In a 2002 article in USA Today, the Quality Education Data Inc., an education market research group, found that schools with large Hispanic student populations suffer from the most teacher shortages in the United States. The schools with predominantly Hispanic populations have 2 to 3 times more teacher shortages than predominantly African-American and Caucasian schools (Henry, 2002).

Another issue confronted by ESL students is that of teacher motivation and attitude. Krahsen (1981) and Garcia (1999) both stress the importance of teacher attitude and its effect on students' self-esteem, motivation, and anxiety (Smith, 2004, p. 1). In a study conducted by Smith (2004), the gamut of teacher attitudes toward ESL students ranged from, "I should not have to deal with them” to "I really understand the difficulties 
that an ESL student faces” (p. 2). With such variety of teacher responses, our understanding of how these attitudes are manifested in the classroom can be important. These attitudes also warrant investigation of how teachers approach tasks of educating those who are not proficient in English.

After focusing on various issues affecting the large numbers of ESL currently present in U.S. schools, we should also examine how this growth affects those responsible for imparting the students' education: the teachers. Since the provisions of No Child Left Behind, ELL students often have no longer been in separate, self-contained classrooms with an ESL teacher. English Language Learners regularly find themselves in mainstream classes with native English speakers from the time they first arrive in the school system. Such practice brings the question of teacher training to the forefront of how to properly educate all ESL students. Furthermore, teacher training now becomes particularly important for teachers in 'the new settlement states' (Zehr, 2006, p. 2) who are not generally accustomed to having large ESL populations. No Child Left Behind (NCLB) education reform and Common Core requires school districts to report on the achievement of ELLs, school systems throughout the county; thus, necessitating an addressing of training teachers. Like the Beaufort County School System, many school systems had to decide how to best train teachers who may not have received ESL training/certification as part of their standard teacher education program.

\section{What works and what does not work with ELLs}

In a study conducted from 2002 to 2006 by the Council of the Great City Schools, four large school districts from various locations in the United States were chosen in order to examine what practices helped ELLs to make the most gains. Based on the 
findings from school districts in Dallas, New York City, San Francisco, and St. Paul, the Council of the Great City Schools was able to identify common factors that helped ELLs experience significant gains in achievement based on three commonalities among the school districts. The first area is a "Shared Vision for Reform" (Council, 2009, p. 2). The NCLB reform is seen as a method of improving and supporting a district-wide reform in instructional practices. It also offers a systematic strategy and approach to improving ESL instruction and ELL services. The second contextual feature is "Leadership and Advocacy on Behalf of ELLs” (Council, 2009, p. 2). In the districts that posted ELL improvements, advocated were successful in gaining support for reforming agendas and improving in ELL instruction. Under the subcategory of, "Empowerment of the ELL Office”, the director and departments of ELL programs were given the power to establish district-wide initiatives and practices (Council, 2009, p. 2). Additionally, the ELL leaders and offices were included in the decision making processes for the programs.

Under the category of "Promising Practices," there are eight subcategories. However, four are important to the scope of this research study. The first promising practice is "Comprehensive Planning and Adoption of Language Development Strategies for ELLs" (Council, 2009, p. 2). What researchers found different in these four schools districts was the manner in which reform initiatives were implemented. Instead of falling under the umbrella district-wide reform strategies to improve reading and literacy, ELLs were separated out and given their own specific goals. Secondly, the districts provided “Extensive and Continuous Support for Implementation” (Council, 2009, p. 2). Initiatives aimed at improving ELL achievement were laid out as long term goals and were given "with clear guidance, tools, and oversight from the central office" (Council, 2009, p. 2). 
Another promising practice included "High Quality, Relevant Professional Development” (Council, 2009, p. 3). The professional development in these districts was described by researchers as, "rigorous and long-term, providing educators with hands-on, site-based strategies for ELL instruction” (Council, 2009, p. 3). Finally, the last promising practice included "Reallocation and Strategic Use of ESL Funds". The improving school districts utilized, "both increased funding and the strategic reallocation of existing resources" in order to improve their programs (Council, 2009, p. 3).

Table 15. Summary of Commonalities Related to Underlying Conceptual Framework

\begin{tabular}{|l|l|}
\hline Commonality: & $\begin{array}{l}\text { Element from Conceptual } \\
\text { Framework: }\end{array}$ \\
\hline Shared Vision for Reform & Policy and Leadership \\
\hline Leadership and Advocacy on Behalf of ELLs & Leadership \\
\hline Empowerment of the ELL Office & Policy and Leadership \\
\hline
\end{tabular}

Table 16. Summary of Promising Practices as Related to Underlying Conceptual Framework

\begin{tabular}{|l|l|}
\hline Promising Practice: & $\begin{array}{l}\text { Element from Conceptual } \\
\text { Framework: }\end{array}$ \\
\hline $\begin{array}{l}\text { Comprehensive Planning and Adoption of } \\
\text { Language Development Strategies for ELLs }\end{array}$ & $\begin{array}{l}\text { Policy, Leadership, and Teacher } \\
\text { Training }\end{array}$ \\
\hline $\begin{array}{l}\text { Extensive and Continuous Support for } \\
\text { Implementation }\end{array}$ & Policy and Leadership \\
\hline $\begin{array}{l}\text { High Quality, Relevant Professional } \\
\text { Development }\end{array}$ & Teacher Training \\
\hline Reallocation and Strategic Use of ESL Funds & Leadership \\
\hline
\end{tabular}

Finally, the Council identified 8 common factors that were detrimental to ELL students' improvement based on research from school districts that were not improving in ELL achievement. The eight factors are presented below as well as how they relate to the conceptual framework for this study. 
Table 17. Eight Detrimental Factors as Related to Underlying Conceptual Framework

\begin{tabular}{|l|l|}
\hline Detrimental Factor: & $\begin{array}{l}\text { Element from Underlying Conceptual } \\
\text { Framework: }\end{array}$ \\
\hline $\begin{array}{l}\text { No coherent vision or strategy for the } \\
\text { instruction of ELLs system-wide }\end{array}$ & Lack of Policy and Leadership \\
\hline $\begin{array}{l}\text { Site-based management with support, oversight, } \\
\text { or explicit accountability for student } \\
\text { progress }\end{array}$ & Lack of Policy and Leadership \\
\hline Lack of access to the general curriculum & Lack of Teacher Training \\
\hline No systematic use of disaggregated student data & Lack of Policy and Leadership \\
\hline Inconsistent leadership & Lack of Leadership \\
\hline $\begin{array}{l}\text { No systematic efforts to build ELL staff } \\
\text { capacity }\end{array}$ & $\begin{array}{l}\text { Lack of Policy, Leadership, and Teacher } \\
\text { Training }\end{array}$ \\
\hline $\begin{array}{l}\text { Compartmentalization of ELL departments and } \\
\text { staff }\end{array}$ & Lack of Policy and Leadership \\
\hline The ELL office lacked capacity and authority & Lack of Policy and Leadership \\
\hline
\end{tabular}

When analyzing the strategies used in classrooms with ELLs, Garcia (1992) found 8 strategies that worked well with students. However, a study by Thompson (2000) compiled a list of ineffective instructional strategies for ELLs as reported by the students themselves.

Table18. Summary of Effective and Ineffective Strategies for ELLs

\begin{tabular}{|l|l|}
\hline What works well: & What doesn't work well: \\
\hline $\begin{array}{l}\text { High levels of communication between } \\
\text { students and teachers }\end{array}$ & Forced to read in public \\
\hline $\begin{array}{l}\text { Integration of language skills into } \\
\text { subject area instruction }\end{array}$ & $\begin{array}{l}\text { Segregation from native English } \\
\text { Speakers }\end{array}$ \\
\hline Themed instruction & Being ignored in class \\
\hline Collaborative group learning & Being embarrassed by teachers in class \\
\hline Native language allowed in classroom & Lack of support \\
\hline Teachers advocate for students & Covering information too quickly \\
\hline Principals support ESL teachers & \\
\hline ESL parents involved in school & \\
\hline
\end{tabular}




\section{Critical Literacy, Critical Pedagogy, and ELLs}

When analyzing Garcia's 8 effective strategies for ELLs (1992), the link between student success through critical pedagogy or critical literacy clearly emerges. In turn, Thompson's ineffective instructional strategies are also directly linked to other issues critical theorists find that 'Others' often confront. Strategies such as being forced to read in public, being ignored or embarrassed in class, not providing support, and covering information too quickly are all methods of marginalizing or segregating ELLs from native-English speakers.

Table 19. Garcia's 8 Effective Strategies and Their Link to Student Success

\begin{tabular}{|l|l|}
\hline Strategy: & $\begin{array}{l}\text { How it Relates to Success for } \\
\text { 'Others': }\end{array}$ \\
\hline $\begin{array}{l}\text { High levels of communication between students } \\
\text { and teachers }\end{array}$ & Critical pedagogy \\
\hline $\begin{array}{l}\text { Integration of language skills into subject area } \\
\text { instruction }\end{array}$ & Critical literacy and critical pedagogy \\
\hline Themed instruction & Critical pedagogy \\
\hline Collaborative group learning & Critical pedagogy \\
\hline Native language allowed in classroom & Critical literacy and critical pedagogy \\
\hline Teachers advocate for students & Critical pedagogy \\
\hline Principals support ESL teachers & Critical pedagogy \\
\hline ESL parents involved in school & Critical literacy and pedagogy \\
\hline & \\
\hline
\end{tabular}

\section{Response in South Carolina}

The South Carolina State Department of Education published an English Language Learning Handbook (2001) that "is intended to provide guidance, and assistance to all local educational agencies (LEAs) in understanding the basic requirements and guidance for policies, procedures, and practices for enrolling, identifying, serving, and assessing English language learners (ELLs)” in South Carolina schools (p.4). The objective of the South Carolina Department of Education (SCDE) in preparing all of these documents for the state's school is to ensure "that all students 
become proficient in English and can achieve the state academic content standards and state student academic achievement standards” (p. 5). The paragraphs below summarize the requirements from South Carolina's Department of Education (SCDE) for policy, strategies for implementation, leadership, teacher training and credentials when working with ELLs.

\section{Policy}

With respect to policy, any student entering a South Carolina school is required to take a Home Language Survey. If a language other than English is spoken at home, the student is evaluated for English language proficiency to determine if ESOL services are needed. If a student needs ESOL classes, he/she is assigned an individual support team to determine what type of support to provide the student based on the Home Language Survey, the language proficiency test, the student's home and educational background, and the student's demonstrated content knowledge and skills (ELLH, p. 8). Each school in South Carolina is required to design and implement a comprehensive plan for education ELLS in the school. The plan should

address each aspect of the LEA's program for all ESOL students, at all grade levels, and at all schools in the school system. It should contain sufficient detail and specificity so that each staff person can understand how the plan is to be implemented and should contain the procedural guidance and forms used to carry out responsibilities under the plan (ELLH, p.11).

The effectiveness of a school district's ESOL instruction and student progress is monitored by two sources: statewide assessments and the English Language Development Assessment (ELDA). If the assessment results show that ESOL students in district are not making adequate progress, the district itself has the freedom to change models of instruction as necessary (ELLH, p. 9). 
Students remain in ESOL courses until they have reached the "fluent level" for two years on the state English language proficiency test. Additionally, the student must pass South Carolina's statewide assessments with a score of "met expectations" or better (ELLH, pp. 6-7, 10). Once students have met these two conditions, they are removed from ESOL classes. However, the school must follow-up with students for two additional years once they have exited the program. If the student is not academically successful once leaving the ESOL program within those 2 years, further ESOL support is provided (ELLH, pp. 6-7, 10).

\section{Strategies for implementation}

Strategies for implementation in South Carolina schools are left to the discretion of each school district. The SCDE allows for this flexibility due to the fact that "the number of students may vary form only a few in some LEAs to several thousand in others” (p. 20). Therefore, each district is allowed to decide which model of English learner instruction is best for the circumstances of each school in the district. The only parameters provided by the state is that it must be come from one of the following "scientific research-based models of instruction" such as content-based ESOL instruction, ESOL pullout, Structured Immersion with ESOL methodologies, sheltered instruction, newcomer program, or inclusion (ELLH, pp. 22-23).

\section{Leadership in Beaufort County}

ESOL leadership in each school district of South Carolina begins with an ESOL

Coordinator. The coordinator is described as,

a liaison for school personnel, parents, and the community. The Coordinator must work diligently with teachers and other administrators to assure that LEP students are identified and served” (ELLH, p. 30). 
Furthermore, it is also the duty of ESOL Coordinators of each district to provide training to all school personnel including administration, teachers, and staff in order to guarantee that all LEP student needs are met.

\section{Sarah Owen}

As highlighted in Chapter 1, Beaufort County's ELL students experienced a massive change in their overall academic performance over the past few years. Beaufort County's ELLs were performing poorly and on par with other ELLs of the Deep South; however, that changed after 2005 when Sarah Owen was hired as the Beaufort County ESOL Coordinator. Since that time, ELL student achievement in Beaufort County has grown exponentially and with win award-wining results. Therefore, this success necessitates investigating the role of a specific leader in bringing about positive change in the ELLs academic experience.

Table 20. Percent of LEP students proficient on state assessments in Beaufort County, South Carolina when Sarah Owen was hired and after

\begin{tabular}{|l|l|l|l|}
\hline Assessment & $\begin{array}{l}\text { Beaufort County, } \\
\text { South Carolina in } \\
\mathbf{2 0 0 5}\end{array}$ & $\begin{array}{l}\text { Beaufort County, } \\
\text { South } \\
\text { Carolina in 2012 }\end{array}$ & $\begin{array}{l}\text { Growth } \\
\text { Percentage }\end{array}$ \\
\hline $4^{\text {th }}$ Grade Reading & $33.3 \%$ & $64 \%$ & $92.2 \%$ \\
\hline $4^{\text {th }}$ Grade Math & $41.3 \%$ & $72.8 \%$ & $76.3 \%$ \\
\hline $8^{\text {th }}$ Grade Reading & $12.2 \%$ & $48.3 \%$ & $295.9 \%$ \\
\hline $8^{\text {th }}$ Grade Math & $14.1 \%$ & $48 \%$ & $240 \%$ \\
\hline $\begin{array}{l}\text { High School } \\
\text { Assessment Program } \\
\text { (HSAP) }\end{array}$ & $36.0 \%$ & $87.3 \%$ & $142.5 \%$ \\
\hline
\end{tabular}

(Source: www.eddataexpress.gov)

\section{Teacher training and credentials}

The state of South Carolina outlines several requirements with respect to teacher training and credentials when working with ESOL students. The teacher must hold ESOL 
endorsement. The teacher must have certification ${ }^{8}$ in another area and then obtain the fifth-year ESOL teacher endorsement. If teachers do not hold the ESOL endorsement ${ }^{9}$ on their license, they must obtain it by the deadline the school district gives. The additional requirements for ESOL teachers in the state include:

1) full English Proficiency in reading, writing, listening, speaking, and comprehension;

2) a thorough knowledge of the theory and practice of ESL;

3) a genuine concern for the education of students from different linguistic and cultural backgrounds;

4) awareness of the various cultures of LEP students;

5) an understanding of the basic concepts regarding the nature of language and the theories of first and second language acquisition;

6) the ability to teach students how to interact successfully in a cross-cultural setting and how to maintain pride in their native culture;

7) an understanding of different cultures and the effect that those cultures have on students' learning styles and on their general level of development and socialization;

8) the ability to use various teaching techniques chosen according to the needs of the students and demands of the subject matter;

9) the ability to facilitate contacts and interaction between the student's home and the school;

10) the willingness to work closely with mainstream teachers of ELLs so that regular teachers receive the English proficiency information they must have for the ELLs in their classrooms, are aware of appropriate accommodations,

\footnotetext{
${ }^{8}$ ESOL certification is when a teacher holds a teaching license only to teach ESOL and not a specific subject area.

${ }^{9}$ In the state of South Carolina, an ESOL endorsement is an additional credential that teachers can add to their subject-area state teaching license. It is obtained by completing an additional one-year, six-course program with a concentration in either English as a Foreign Language (EFL) for overseas teaching positions or K-12 ESOL (http://artsandsciences.sc.edu/tesol-certificate-program).
} 
and learn about the best teaching methodologies to use with their ELLs. The ESOL teacher should support the academic standards being taught in mainstream classrooms” (ELLH, pp.30-31).

The previously cited studies will provide a foundation for this research study. Unlike Beaufort County, the school districts utilized in the Council Study (2009) are very large districts with large budgets. Additionally, they are areas of the country that have traditionally had large ELL populations. The findings of the previously cited studies will be used to see if the Beaufort County teachers have implemented the recommended best practices strategies and methodologies in their own classrooms. Another aspect this study will seek to analyze is how the ELLs of Beaufort Country have been able to accommodate and assimilate into U.S. classrooms and society so quickly. When analyzing the trend in Beaufort County’s ESL students’ record achievement scores, a very clear pattern emerges. The recent success of this school system's ESL population came after the hiring of Sarah Owen as the ESL Coordinator in 2002. Under her leadership, this relatively small school system has posted record gains in ESL student achievement. This research study will seek to find out what it is Mrs. Owen has done to prevent the marginalization of this particular group of language and ethnic minorities. Finally, attitudinal research will be used to gauge the teachers' attitude and methodologies while working with the recent phenomenon of such a large ELL population in the Beaufort County schools.

\section{Critique of Literature Review}

Based upon the literature review, there are abundant sources available on how to properly education ELLs. These sources include everything from teaching methodologies that work, those that do not work, required teacher training and credentials, and 
successful program models. Nevertheless, there are several key issues that plague ELLs in U.S. schools. Some of those issues include high drop-out rates, low graduation rates, high failure rates on standardized tests, ill-prepared teachers, and negative teacher attitudes. Given the amount of research on these topics, the leaders of a school system know in which areas problems are likely to arise when educating ELLs. However, the literature does not offer much advice on how to correct these issues nor do failing school systems seem to be implementing experts’ advice. Thus, this research study will examine and be limited to one school system where ELLs are successful- Beaufort County, South Carolina. The candidates for examination in this school system will focus on the elements of ESL policy, leadership, and teacher training and how these three candidates have contributed to ESL student success in this one particular county. Finally, the best sources for ascertaining the role of ESL policy, leadership, and teacher training in ESL student success in Beaufort County, South Carolina is the leadership and teachers of Beaufort County themselves.

\section{Emerging Research Questions}

There are massive amounts of research written about how to teach languages and how languages are learned; yet, ELLs are finding it very difficult to succeed in U.S. schools. Therefore, it is important to study school systems that are successful with ELLs and to analyze their formula for success. Where does this success come from? Does it come from the state’s ESL policy as written, from ESL leadership in a school district, or from the teachers themselves?

The second question that emerges from the research is on the methodologies teachers use in the classroom to lead to student success. Are the teachers of Beaufort 
County doing something different than other school systems in the Deep South? What instructional strategies do they utilize that lead to success among ELLs?

The final point of interest that emerges from the literature is the issue of teacher attitude and training. For many teachers in Beaufort County, working with a large number of ELLs has been a recent phenomenon. The response to the changing population has resulted in some teachers having to return to school to receive ESL endorsements on their teaching license. They have also had to receive additional on-site training on how to properly educate ELLs. This raises the questions of what the teachers' attitudes are toward a change student demographic, of how the teachers felt about having to obtain additional education and training, and what types of training the teachers found beneficial.

Figure 10. Relationship of Conceptual Framework to Emerging Research Questions

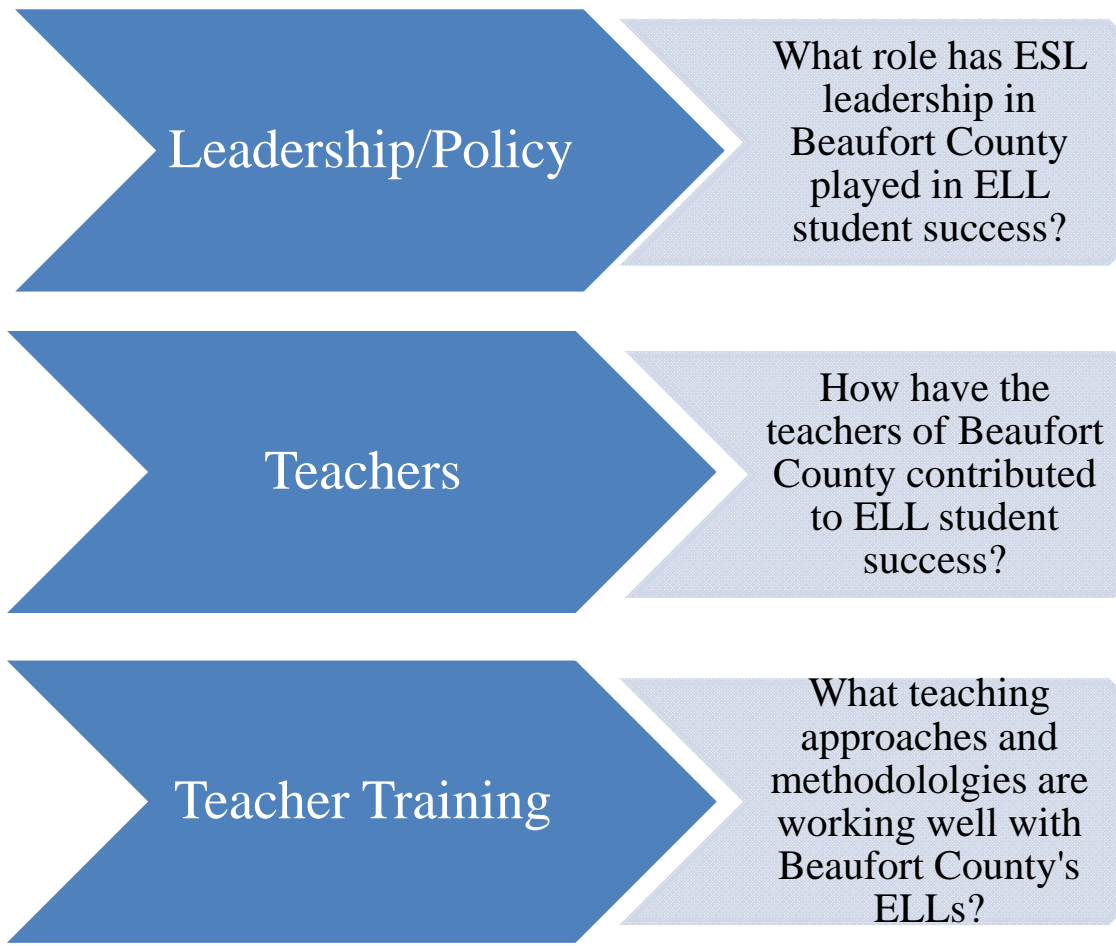




\section{Summary of the Literature Review}

This chapter has presented a summary of the review of literature as it relates to the scope of this study. It took a look at the educational history of the South, important events and legislature affecting bilingual education, how the United States and Beaufort County, South Carolina have experienced a boom in ELL student populations, and it presented the conceptual framework for the study. The second half of the chapter focused on student achievement, the good and bad practices in the ESL teaching profession, issues confronted by ELL students, and how South Carolina responded to the ESL student population boom. Finally, the critique of the literature review and the emerging research questions were discussed. 


\section{CHAPTER III \\ METHODOLOGY}

The purpose of this study is to ascertain why the Beaufort County school system has been successful with the recently arrived ELL student population when so many other regions have not. More specifically, this study seeks to find to how the ESL leadership and the teachers of Beaufort County may have attributed to the success of the ELLs in classroom. This chapter is organized as follows: First, the introduction of the conceptual framework for the research questions, the research design and rationale are explained. Next is the presentation of the research design, setting, and data analysis.

\section{Theoretical Framework}

This case study will be framed by the critical theory. As explained in Chapter 1, the basis of critical theory lies in the struggle between the oppressed and the oppressor. Additionally, this theory states that the purpose of government and education are to prevent class mobility. However, education, one of the very tools used to oppress under this theory, is the only way of breaking this cycle. Given this information, the ESL students of Beaufort County are a population that should have easily been marginalized or 'disenfranchised'. They are immigrants to an area of the country that, until a few years ago, could be divided into two primary groups: Caucasian and African-American. Beaufort County, while showing some signs of change, still maintains many of the customs and traditions of the rural Deep South, some of which include self-imposed separation of the races and not being the most welcoming group of people to outsiders. However, the ESL students of Beaufort County have broken this trend. 


\section{Conceptual Framework}

The ELLS of Beaufort County are succeeding in schools in this community when peer school systems are experiencing mass failure and high drop-out rates with ESL student populations. The success of these students began to happen after the hiring of Sarah Owen as the ESOL Coordinator for the county. Therefore, this study seeks to learn what Sarah Owen did as the ESOL leader of this county to prevent the marginalization of these students. Furthermore, this study seeks to find what those who are in the trenches daily with the students, the teachers, did to attribute to the success of the ELLs in Beaufort County. As a result, the conceptual framework for this study will focus on the roles of ESL policy, leadership, and teachers training for obtaining ESL student success. Additionally, this study will be guided by the following visual representation of the conceptual framework.

Figure 11. Conceptual Framework for ELLs and Mainstream Historical Trends
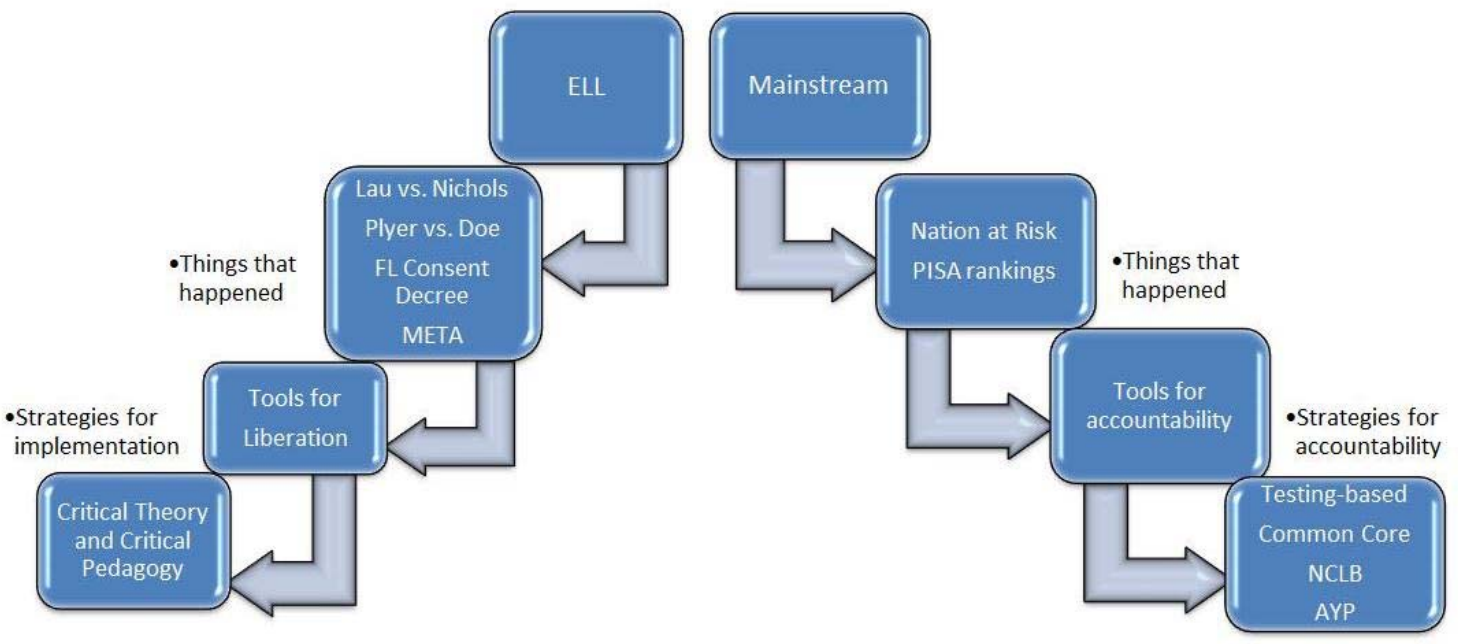


\section{Rational for case study}

According to Gall, Gall, and Borg (2003), qualitative research is used "to discover themes and relationships at the case level" and to focus "on the study of specific cases rather than population and samples” (p. 24). More concretely, this qualitative research study will be conducted as a case study of the Beaufort County School System and its ESL program. Gall, Gall, and Borg (2003) define case study as "the in-depth study of instances of a phenomenon in its natural context and from the perspective of the participants involved in the phenomenon” (p. 619). According to Marshall (1999), "the primary strategy of [case study research] is to capture the deep meaning of experience [from research participants] in their own words” (p. 61). Additionally, case studies report on "a specific organization, program, or process (or some set of these) (Yin, 1989, p. 159). The selection of critical theory as the theoretical framework for this study also supports case study research. One genre of case study research, critical ethnography, is derived from critical theory which "assumes that society is structured by class and status, as well as by race, ethnicity, gender, sexual orientation, to maintain the oppression of marginalized groups” (Marshall and Rossman, 1999, p. 6). Marshall and Rossman (1999) continue to say that critical ethnography was born from critical theory in order to critique accepted teaching practices, to adopt new radical teaching practices, and

to go beyond the classroom to ask questions about fundamental policy, power, and dominance issues and dilemmas in schooling, including the role of the school in reproducing those gender, race, and other social inequities (p. 6).

Gall, Gall, and Borg (2003) expand the purposes of case study research to include possible explanations of a phenomenon (p. 24). As a result, this research method was chosen in order to gain very personal, in-depth information from those who have first- 
hand experience and have contributed to the success rather than the marginalization of Beaufort County's booming ESL population.

The review of the literature has shown that in most states of the Deep South, ELLs have not been performing very well on standardized tests and that very few school systems have posted large successes with ESL students. Furthermore, ELLs are plagued by various other issues such as negative teacher attitude, high drop-out rates, and teacher shortages. Walker, Corcoran, and Wals (2004) state that case studies have “transformative potential” when executed well (p. 18). Therefore, other school systems that are not posting successful numbers with ELLs will have Beaufort County's model of success for ELLs. This information offers other school systems the potential to overhaul their ESL student policy in order to replicate Beaufort County’s successful results.

\section{Research Setting}

Beaufort County is in the southeastern corner of the state of South Carolina. During the 2011-2012 academic year, Beaufort County had a total of 19,995 students and 1,430 teachers in the system. The district is comprised of 11 elementary schools, 8 middle schools, and 5 high schools (www.ed.sc.gov, 2012). I selected this school district for this study based on the changing student population and the gains made by the ESL population in these schools.

\section{Population Sample}

The greater population for this study would include all schools in the United States, that have experienced boom increases in the number of students whose for whom English is a second language. However, because this will be a more focused study, the 
actual population is represented by geographic areas that have experienced recent increases in the number of ESL students.

\section{Research Design}

Data will be collected from Sarah Owen utilizing an interview. In this research study, the following procedures will be utilized for data collection:

1) Contact Sarah Owen, ESL, World Languages, and Gifted and Talented Coordinator: she will be the gatekeeper to the Beaufort County School System.

2) Conduct an interview with Sarah Owen to gather information about the ESL population in the county, her leadership goals, teacher training, and her general perceptions of teacher attitudes towards ESL students.

3) Based on interview with Sarah Owen, create interview questions for 10 Beaufort County teachers recommended by Sarah Owen.

4) Conduct interview with 10 Beaufort County teachers to gain their insight on why ELLs in the county have been so successful.

\section{Interviews}

Interviews are used in qualitative research to gain information, typically from individual respondents. Gall, Gall, and Borg (2003) state that “interviews are used extensively in educational research to collect data about phenomena that are not directly observable: inner experience, opinions, values, interests, and the like” (p. 222). Glesne (1999) expands this purpose of interviews to include soliciting information not only about inner experience and opinions, but she also includes, “perceptions, and attitudes” (p. 69). The advantages to using interviews include the fact that they are very flexible and that 
they make "it possible to obtain information that the individual probably would not reveal by any other data-collection method” (Borg, Borg, and Gall, 2003, p.222). Additionally, these researchers continue to say that qualitative research commonly uses interviews for data collections due to the fact that they "permit open-ended exploration of a topic and elicit response(s) that are couched in the unique words of the respondents” (p. 223). While interviews can be used in various stages of data collection, Glesne (1999) finds that interviews are substantial enough to form the sole basis of a study. She later adds that an interview can be "the basis for later data collection" or be "used in conjunction with data from participant observations and documents” (p. 68). The data resulting from interviews often compose "powerful stories that both inform and inspire" (Willis, 2007, p. 244).

Sarah Owen

I first learned about Sarah Owen from a colleague while I was teaching Spanish for the University of South Carolina in Beaufort. My colleague also taught in the Beaufort County public schools and thought I would be interested in meeting Sarah Owen since I worked in the field of ESL education. Around this same time, several of my students commented to me about the large number of Spanish speakers in their high schools before they began studying in the university. At the time, I was trying to formalize a dissertation topic, so these two events piqued my interest in speaking with Mrs. Owen about the large ESL population in Beaufort County.

Before speaking with Mrs. Owen, I completed the CITI training and the IRB process for the Protection of Human Subjects as required by the university. This training focused on ethical research practices as well as when and how to ensure participant 
confidentiality. Once I received IRB approval for my research, I proceeded to contact Mrs. Owen.

I first contacted Mrs. Owen via her e-mail address which was listed on the Beaufort County School System website. I explained that I was a doctoral student and was interested in studying the Beaufort County school system for my dissertation. She was more than willing to help guide me through the process with the Beaufort County schools system and to schedule an interview with me.

\section{Interview Questions}

When interviewing Sarah Owen, I engaged in what Glesne (1999) calls ‘topical interviewing' (p. 69). Topical interviewing is a form of interview that focuses “more on a program, issue, or process than on people’s lives” (Glesne, 1999, p.69). This

type of interview will allow me to focus on her position as the ESL program Coordinator in Beaufort County and the changes that have taken place since her arrival. As a result, Sarah Owen will serve as my key informant. Gall, Gall, and Borg (2003) define 'key informant' as 'individuals who have special knowledge or perceptions that would not otherwise be available to the researcher” (p. 237).

When developing the interview questions, there are several considerations to be aware of. Some of those considerations include the scope and the purpose of the interview questions. Maxwell (1996) cautions against confusing research questions and interview questions by stating that "your research questions formulate what you want to understand; your interview questions are what you ask people in order to gain that understanding” (p. 74). Therefore, interview questions are more concrete and contextual than research questions, which tend to be very generalized and broad. Glesne (1999) 
continues and expands upon Maxwell's advice about interview questions by stating that interview questions should, “point toward an understanding of the complex phenomenon” being explained and “be drawn from the respondents’ lives” (p. 70).

\section{Semi-structured interviews}

A semi-structured interview is one which involves asking “a series of structured questions and then probing more deeply using open-form questions to obtain additional information” (Gall, et. al., 2003, p. 240). This method of data collection will be used because it allows flexibility for further exploration of other topics and issues that may arise beyond the pre-determined topics or set of questions. This first stage of data collection will seek to provide very specific and personal experiences from Sarah Owen, as they relate to the scope of this study.

\section{Interview with Sarah Owen}

The first step of data collection began by scheduling an interview Sarah Owen, the Coordinator for ESL and Gifted and Talented in Beaufort County, South Carolina. The purpose of this interview was to understand the ESL population change that has taken place in the schools system and the administration's response to this change. Additionally, I will need Sarah’s support as the gatekeeper in order to receive permission to conduct the other steps of data collection.

When conducting interviews, Glesne (2003) says that "convenient, available, appropriate locations need to be found” (p. 75). I scheduled the interview with Sarah Owen via e-mail. Because she often traveled to different schools throughout the county, she agreed to meet with me at the University of South Carolina Beaufort Campus given that it was close to a school she would be visiting. I initially met her in the reception area 
of the school. In accordance with Glesne's (2003) recommendation of keeping interviews to around an hour in length, we spoke for approximately one hour and fifteen minutes (p. 78).

During the interview, I used my interview guide for the fixed questions and took notes on her responses. There were some additional questions that arose and that were not included on the interview guide. As Ms. Owen responded to the questions, I took notes on her answers by hand on the interview guide. Glesne validates this method of recording information as the interviewee often finds it "less obtrusive and less intimidating” than recording the interview or using a computer to take notes (p. 78). Once the interview was finished, I immediately returned to my office to type out Ms. Owen’s complete responses to each questions while the information was still fresh in my mind.

During the interview, I found Ms. Owen to be extremely informative about the changes that have taken place in the Beaufort County schools system and very easy to talk to. She appeared to be confident and at ease throughout the entire interview.

\section{Data Analysis}

Preparing for the interview with Sarah Owen also helped with the data analysis. The interview questions were guided by the research questions and my literature review. Gall, Gall, and Borg (2003) state that data analysis in qualitative research "is likely to be emergent” as the data may yield to "new constructs, hypotheses, and insights" (p. 283). Data analysis for the interview with Sarah Owen began to take place after transcribing my hand-written notes on the computer. Once I had transcribed my notes, I began to read them copiously to search for Sarah Owen’s insight into why Beaufort County has been successful with ELLs. Glesne(1999) recommends that once a researcher reads through 
the data, the important elements must be identified and given a name known as a code (p. 136). She continues to say that in qualitative research "each major code should identify a concept, (or) central idea” (p. 136).

After interviewing Mrs. Owen, I did find that my data yielded "new contracts, hypotheses, and insights” (Gall, Gall, and Borg, p. 283, 2003). I had a completely different expectation of the type of information the data from the interview would yield. I expected to hear a story of mass student failure rates, negative teacher attitudes, marginalization of students, and of a school system that was really not happy with having to accommodate so many non-English speakers. These expectations were completely wrong.

Based on my interview with Sarah Owen, I was able to form elementary coding schemes for the data based on the reoccurring themes of the interview. The elementary coding schemes for data included: leadership (LDR), policy (POL), and teacher training (TT). These coding schemes were useful in the second step of data collection as they helped “to develop a more specific focus or more relevant questions” (Gall, Gall, and Borg, 2003, p. 133) for additional interviews with Beaufort County's teachers.

\section{Interviews with ESL and Mainstream Teachers}

\section{Protection of Human Subjects}

Due to the sensitive nature of some of the responses this research study expects to elicit, every precaution will be taken to protect the identity of the participants. Participants were identified simply by a number and not their names. Any identifying information will be used only for summarized statistical purpose and will be seen only by the researcher. Furthermore, I informed all of the participants that no identifying 
information would be used in the published study. Gall, Gall, and Borg (2003) stated that "anonymity might be necessary if highly personal or threatening information is required" (p. 227). In hopes of eliciting more candid responses to interview questions, I promised anonymity to the teachers. Additionally, I did not want the study participants to confront any negative feedback from colleagues who might not be in agreement with what the teachers had to say.

\section{Semi-structured interview questions}

In order to receive final permission to conduct the interviews, I first had to provide Sarah Owen a copy of the structured questions for her approval. Given that I had to submit my structured interview questions for approval before being allowed to conduct the teacher interviews, they will be given early in this section of the research study. The questions were formed based on the interview with Sarah Owen, the candidates for examination from the conceptual framework, and the emerging research questions. 
Table 21. Relationship between ESL teacher interview questions and conceptual framework/emergent research questions

\begin{tabular}{|c|c|}
\hline Question: & $\begin{array}{l}\text { Candidate from Conceptual } \\
\text { Framework/Emergent Research } \\
\text { Questions: }\end{array}$ \\
\hline $\begin{array}{l}\text { 1. Are you ESOL certified? How long have you } \\
\text { held the ESL certification? }\end{array}$ & Teacher Training \\
\hline $\begin{array}{l}\text { 2. When did you first begin to notice a change } \\
\text { in the ESL student population of Beaufort } \\
\text { County? }\end{array}$ & Teacher Attitude \\
\hline $\begin{array}{l}\text { 3. In general, what were the teachers' reactions } \\
\text { to the changing student population? Were they } \\
\text { positive or negative? Please explain. }\end{array}$ & Teacher Attitude \\
\hline $\begin{array}{l}\text { 4. What steps did the school system take in } \\
\text { order to ensure that teachers were prepared to } \\
\text { handle and adapt to the changing ESL student } \\
\text { population? }\end{array}$ & Policy and Leadership \\
\hline $\begin{array}{l}\text { 5. Did the school system provide any system } \\
\text { wide training or workshops? If yes, please } \\
\text { explain. }\end{array}$ & Teacher Training and Leadership \\
\hline $\begin{array}{l}\text { 8. As an ESOL teacher, did you offer any } \\
\text { training within your respective schools to help } \\
\text { prepare non-ESOL certified teachers? If yes, } \\
\text { what was that training? }\end{array}$ & Teacher Training, Policy, and Leadership \\
\hline $\begin{array}{l}\text { 9. In your experience, have non-ESOL certified } \\
\text { teachers found the training they have received } \\
\text { (from you or the school system) useful in their } \\
\text { classrooms? Please explain. }\end{array}$ & Teacher Training and Teacher Attitude \\
\hline $\begin{array}{l}\text { 10. Which training did they find the most } \\
\text { useful and the least useful? }\end{array}$ & Teacher Training \\
\hline $\begin{array}{l}\text { 11. In your experience, do mainstream teachers } \\
\text { modify their teaching approaches to } \\
\text { accommodate the ESOL student population? }\end{array}$ & Teacher Training \\
\hline $\begin{array}{l}\text { 12. What advice can you offer other school } \\
\text { systems facing the issue of successfully } \\
\text { accommodating a rapidly increasing ESOL } \\
\text { population? What worked well in Beaufort } \\
\text { County during this process and what did not } \\
\text { work well? }\end{array}$ & $\begin{array}{l}\text { Teacher Training, Teacher Attitude, Policy, } \\
\text { and Leadership }\end{array}$ \\
\hline $\begin{array}{l}\text { 13. The ESL population in Beaufort County } \\
\text { has recently posted record gains and received } \\
\text { awards for scores on assessment tests. In your } \\
\text { opinion, what has contributed to these gains? }\end{array}$ & $\begin{array}{l}\text { Teacher Training, Teacher Attitude, Policy, } \\
\text { and Leadership }\end{array}$ \\
\hline
\end{tabular}


Table 22. Relationship between mainstream teacher interview questions and conceptual framework/emergent research questions

\begin{tabular}{|c|c|}
\hline Question: & $\begin{array}{l}\text { Candidate from Conceptual } \\
\text { Framework/Emergent Research } \\
\text { Questions: }\end{array}$ \\
\hline $\begin{array}{l}\text { 1. Are you ESL certified or currently } \\
\text { working towards it? }\end{array}$ & Teacher Training, Policy \\
\hline $\begin{array}{l}\text { 2. Did you receive ESL training as part of } \\
\text { your initial teacher education program? }\end{array}$ & Teacher Training \\
\hline $\begin{array}{l}\text { 3. Have you received ESL training through } \\
\text { your currently employer? }\end{array}$ & Teacher Training, Policy, and Leadership \\
\hline 4. Did you find this training beneficial? & Teacher Training, Teacher Attitude \\
\hline $\begin{array}{l}\text { 5. Which trainings did you find the most } \\
\text { and the least beneficial? }\end{array}$ & Teacher Training, Teacher Attitude \\
\hline $\begin{array}{l}\text { 6. Do you differentiate instructions for ESL } \\
\text { students? How often? What types of } \\
\text { differential instruction do you use? }\end{array}$ & Teacher Training \\
\hline $\begin{array}{l}\text { 7. Do you provide LEP students with } \\
\text { alternative forms of assessment? }\end{array}$ & Teacher Training \\
\hline $\begin{array}{l}\text { 8. How often do you slow the rate of } \\
\text { instruction for LEP students? }\end{array}$ & Teacher Training, Teacher Attitude \\
\hline $\begin{array}{l}\text { 9. How often do you find LEP students are } \\
\text { "lost" in your class(es)? }\end{array}$ & Teacher Training, Teacher Attitude \\
\hline $\begin{array}{l}\text { 10. Do you feel native-English speakers } \\
\text { benefit by having LEP students in class? }\end{array}$ & Teacher Attitude \\
\hline $\begin{array}{l}\text { 11. Do you modify your teaching } \\
\text { approaches/methodologies in order to } \\
\text { accommodate LEP students? How often? }\end{array}$ & Teacher Training \\
\hline $\begin{array}{l}\text { 12. Do you find that having LEP students } \\
\text { in courses lowers classroom standards? }\end{array}$ & Teacher Training, Teacher Attitude \\
\hline $\begin{array}{l}\text { 13. Do you feel adequately prepared to } \\
\text { teach LEP students? }\end{array}$ & $\begin{array}{l}\text { Teacher Training, Teacher Attitude, Policy, } \\
\text { Leadership }\end{array}$ \\
\hline $\begin{array}{l}\text { 14. Do you receive training from your } \\
\text { school system on how to teach LEP } \\
\text { students? How often? }\end{array}$ & Teacher Training, Policy, Leadership \\
\hline $\begin{array}{l}\text { 15. In your opinion, what is greatest barrier } \\
\text { you have encountered in working with a } \\
\text { large ELL population? }\end{array}$ & Teacher Training, Teacher Attitude \\
\hline $\begin{array}{l}\text { 16. What recommendations or suggestions } \\
\text { could you give other school systems facing } \\
\text { the issue of accommodating a large ELL } \\
\text { population? }\end{array}$ & Policy, Leadership, Teacher Training \\
\hline
\end{tabular}




\section{Study Participants}

The study participants were composed of a total of 10 Beaufort County teachers. Four of the teachers were ESL lead teachers in the schools and six of the participants were mainstream teachers. Once I obtained permission from Sarah Owen and her supervisor, I was given the contact information of the four ESL teachers. The other six teachers were randomly selected from schools in Beaufort County with large ESL populations. Sarah Owen recommended 3 schools that house large ESL populations and gave me the contact information of the school principal. I contacted the school principal via e-mail stating the purpose of my research and asking him/her to recommend 2 mainstream teachers to participate in the study. Once I received the contact information

of the 6 mainstream teachers, I sent an e-mail to all 10 research participants. Each e-mail contained the scanned attachment giving me permission from Sarah Owen and her supervisor to conduct the research, a consent decree declaring that each person was a willing participant and had the right to withdraw at any time, and my declaration of participant anonymity.

\section{Data Collection}

I began this step of data collection by first interviewing the ESL lead teachers. Due to the long distance between Beaufort, South Carolina and Miami, Florida, the lead teacher interviews took place in three steps. Once I received each teacher's consent to participate, I contacted each teacher to ask if he/she preferred to complete the interview via e-mail or via telephone. All 4 teachers preferred to complete the structured questions via e-mail. I sent them a copy of the structured interview questions via e-mail along with an e-mail from Sarah Owen approving my research questions. Each teacher typed his/her 
response to the questions and e-mailed their responses to me. The follow up questions were also sent and answered via e-mail. This same process was followed with the mainstream teachers.

\section{Data Security}

As previously stated, study participants were granted anonymity. In order to protect participants' identity, I was the only person with access to the interview data. This data was stored on my computer in my office at work. My computer is protected by a password which only I know. Additionally, my office is always secured by lock and key. Finally, all of the interview data will be destroyed once this study is complete.

\section{Triangulation of Data}

Gall et. al (2003) define triangulation in qualitative research as the process of using multiple data-collection methods, data sources, analysts, or theories to check the validity of the case study findings. Triangulation helps to eliminate biases that might result from relying exclusively on any one datacollection method, source, analyst, or theory (p. 464).

Erzerberger and Prin (1997) state that the primary function of triangulation is "to explore convergence, complementarity, and dissonance" that "enhance the validity of the research by increasing the likelihood that the findings and interpretations will be found credible and dependable” (Farmer, et al, 2008, Lincoln and Guba, 1985). One form of qualitative data triangulation as identified by Denzin (1978) is collecting data from multiple sources. This was the type of data triangulation utilized for this research study. The data were collected from a total of 11 sources: Sarah Owen, the ESL, and the mainstream teachers. Next, ESL and mainstream teachers' interviews were followed up1-2 weeks later to 
verify the respondents' answers. This follow-up also provided the opportunity to probe deeper and to clarify the participants' responses.

\section{Validity}

According to Gall, Gall, and Borg (2003), validity with case studies presents a large difficulty because "case study researchers do not agree in their assumptions about the nature of reality and scientific inquiry” (p. 460). Given that case studies report on participants' interpretation of a phenomenon "some researchers have concluded that traditional notions of validity and reliability do not apply to case study data and interpretations” (Gall, Gall, and Borg, 2003, p. 462). As such, Robert Yin has developed one reliability criterion and three validity criteria for case study research that mirror measures of validity for quantitative research. Yin's measures of validity for case study include:

1) Construct validity includes to what extend the concepts being studied are correctly operationalized.

2) Internal validity looks as the relationship of causality between two phenomena. If the findings of a case study are generalizable to other similar cases, this strengthens external validity;

3) Reliability measures whether or not other researchers would replicate the results when using the same procedures as the original case study (Gall, Gall, and Borg, 2003, p. 460).

As reported by Gall, Gall, and Borg (2003), validity is also strengthened if a researcher presents a strong 'chain of evidence' (p. 461). A chain of evidence includes "meaningful links between research questions, raw data, and findings" (p. 461). The 
chain of evidence for this study has been shown through the introduction to the research topic, the review of the literature, the data collection sources, and the data collection methods. The research problems were derived from background information on ELLs academic performance in U.S. schools. The literature review focused on ESL policy, leadership, and teacher training as tools for obtaining student achievement. Finally, the data was collected via interviews in order to gain personal, first hand feedback from an ESL coordinator, ESL, and mainstream teachers who seem to have successfully accommodated a large ESL population within a short amount of time.

\section{Role of the researcher}

During the process of this study, I have taken a positivist research stance. The goal of the positivist stance is "to keep the self out of the process of collecting data and reporting their findings as much as possible” (Gall, Gall, and Borg, 2003, p. 17).

Furthermore, Gall, Gall, and Borg (2003) state positivists believe that "objective knowledge about the world is possible” (p. 460). I have reported Sarah Owen's and the teachers' responses verbatim without interjecting my own thoughts or opinions. The only editing done to the teachers' responses focused on combining information or making grammatical corrections. My goal is this study was to directly report from first-hand sources, Sarah Owen and the teachers, their thoughts on why the ESL program in Beaufort County has been successful.

\section{Summary}

This chapter focused on data collection for this research study. The conceptual framework for the research, the research design, setting, and sample were presented. Additionally, using interviews as a source of data collection from Sarah Owen and 10 
Beaufort County teachers was discussed extensively. Finally, this chapter explained how the interview data was analyzed, and the issues of triangulation and validity were discussed. 


\section{CHAPTER IV}

\section{RESULTS}

This chapter presents the results from my interviews with Sarah Owen and 10 Beaufort County teachers. The chapter begins by explaining the state Beaufort County’s ESL program in 2001 and the county's responses to the ESL population boom in 2005. Next is Sarah Owen's biography and what the ESL program was like when she became the ESL Coordinator. The following part of the chapter focuses on the changes she made to Beaufort's ESL program, her thoughts on why the ELLs in Beaufort County schools are successful, and obstacles the students confront. The final part of the chapter presents the results from the interviews with 10 Beaufort County teachers- four of whom were ESL-certified lead teachers in the schools, and the other 6 mainstreamed subject area teachers.

\section{Hispanic boom in Beaufort County and the school system's response}

The Beaufort County School System first responded to its Hispanic population boom in 2001 with 4 itinerant teachers who would travel between various schools in the district to work with the English language learners. By 2005, the ESL population had become so large that the school system hired Sarah Owen as Coordinator for Gifted and Talented, ESOL, and World Languages.

\section{Biography}

Based on my interview with Sarah Owen, I learned the following information about her and the Beaufort County, South Carolina ESOL program. Mrs. Owen is originally from Boston, Massachusetts and holds a degree in Elementary Education from Pittsburg State University in Pennsylvania. After graduating, she accepted a position in a 
Title I school in Arlington, Texas because she spoke Spanish and there was a high demand for ESOL teachers in the area. The school where she taught at had a student body that was 87\% Limited English Proficient (LEP). She obtained her ESL certification while working in Texas because the school system offered to pay for the certification courses. She later obtained a Master's in Curriculum and Instruction. She then became the ESOL lead teacher at her school in Arlington, Texas for 4 years and has National Board Certification for ESOL. She has been working with the ESOL program in Beaufort County, South Carolina since 2002, and she has been the coordinator since September of 2006.

\section{Beaufort County ESL before Sarah Owen}

The ESOL program in Beaufort County schools has been in existence in Beaufort for 15 years and used itinerant teachers up until 10 years ago. In 2001, the county began hiring ESOL teachers for certain schools in the district due to the Hispanic student population boom. Approximately $80 \%$ to $85 \%$ of the ESL students in Beaufort County are located in schools in the southern and eastern parts of the county, which is the region south of the Broad River. Previous to Sarah Owen taking over the ESL Coordinator position for the Beaufort County school system, the system-wide method of ELL instruction was the Gateway program ${ }^{10}$. This program of language instruction was initially chosen due to its target audience of lower-level and beginning-level English learners. The Gateway program was later dissolved due to an administration change and the fact that it didn't allow for students to progress. According to Sarah Owen, "higher

\footnotetext{
${ }^{10}$ The Gateway program is a five level program for English instruction produced by Macmillan. It uses classic and modern literature, songs, authentic texts, and an on-line component to teach cross-curricular objectives, international, and popular culture (www.macmillanenglish.com/courses/gateway/).
} 
level students actually saw language loss since the program targeted beginning and lower level students”.

Table 23. Percent of LEP students proficient on state assessments in Beaufort County, South Carolina before Sarah Owen hired as ESOL Coordinator Percent of LEP students proficient on state assessments in Beaufort County, South Carolina

\begin{tabular}{|l|l|l|}
\hline Assessment & $\begin{array}{l}\text { Beaufort County, South } \\
\text { Carolina in 2005 }\end{array}$ & $\begin{array}{l}\text { Beaufort County, South } \\
\text { Carolina in 2012 }\end{array}$ \\
\hline $4^{\text {th }}$ Grade Reading & $33.3 \%$ & $64 \%$ \\
\hline $4^{\text {th }}$ Grade Math & $41.3 \%$ & $72.8 \%$ \\
\hline $8^{\text {th }}$ Grade Reading & $12.2 \%$ & $48.3 \%$ \\
\hline $8^{\text {th }}$ Grade Math & $14.1 \%$ & $48 \%$ \\
\hline $\begin{array}{l}\text { High School Assessment } \\
\text { Program (HSAP) }\end{array}$ & $36.0 \%$ & $87.3 \%$ \\
\hline
\end{tabular}

(Source: www.ed.sc.gov/data/pass/2012/show_state_pass_scores_demo.cfm?ID=999999 and www.eddataexpress.gov)

\section{After Sarah Owen}

According to Mrs. Owen, the type of instruction currently used in the schools depends on the area the school is located in. For the Northern part of the county, where ESOL populations are low, itinerant teachers use the Hampton-Brown ${ }^{11}$ system with high school students. The elementary school students use the OpenBook ${ }^{12}$ program which focuses on reading comprehension with instructions given in Spanish. Middle school students have an ESOL course and elementary school students have pull-out sessions or content-area instruction. Additionally, Mrs. Owen also recently purchased the Rosetta

\footnotetext{
11 The Hampton-Brown system is a series of books called Into English! published by National Geographic. This program seeks to build academic language proficiency through content-area instruction. The series is based on authentic materials and assessments to gauge students' progress. Finally, each theme has a subsection designed specifically for beginning level students (www.ngsp.com/tabid/90/default.aspx).

12 The OpenBook system is an educational software company that teaches reading, writing, speaking, and listening via media-rich computer programs. This program focuses on emergent literacy, literacy development and intervention, and English as a foreign language with first-language support and translation (http://academy.openbooklearning.com/why-it-works/).
} 
Stone language program for the students. In the southern part of the county where the ELL student population is concentrated, students receive content are ${ }^{13}$ and sheltered instruction ${ }^{14}$ or both. The ESL students' content area instruction is the same as the native English speakers. According to Mrs. Owen,

our teachers who teach content area instruction all have ESOL endorsements or are currently working towards earning it. In the southern Beaufort County high schools, the ESL students as a whole have been found to be low in their English proficiency. So, they begin with ESL content instruction. As the students improve their language skills, they move towards sheltered instruction. Finally, these students continue to receive ESOL support by spending at least 1 hour a day with ESOL teacher.

\section{Policy, Leadership, and Teacher Training}

Rather than separating out each candidate of the conceptual framework for the interview with Sarah Owen, I chose to group them together due to the amount of overlap between each theme as related to Sarah Owen's leadership as the ESOL Coordinator for Beaufort County. Improving teacher training has been one of the main penchants of the Beaufort County ESOL program under Sarah Owen’s leadership. During the summer breaks from school, the Center for Applied Linguistics offers courses for regular education teachers, paraprofessionals, and administrators. The regular educational teachers also take additional training from the Center for Applied Linguistics on ESOL teaching methodologies including the Sheltered Instruction Observation Protocol (SIOP) model. Additionally, Mrs. Owen wants her high school teachers to focus on helping ESL

\footnotetext{
${ }^{13}$ Content area instruction is an instructional method for ELL students in which grade level academic content is taught exclusively in English without direct focus on vocabulary or grammar. English-language skills are acquired indirectly through the subject area instruction. (http://ellp.ccsd.net/programs/)

${ }^{14}$ Sheltered instruction takes a similar approach, but it provides a component of direct English-language instruction. Additionally, sheltered instruction takes into account the student's skill level and provides teachers with strategies to teach the content based on that beginning skill level. (http://ellp.ccsd.net/programs/)
} 
students graduate. In order to accomplish this goal, several new procedures were implemented. To begin with, Beaufort County schools currently hold 3 mandated Parent Nights a year exclusively for ESOL parents. Secondly, the members of the ESOL Faculty must give 2 training sessions a year for regular education faculty on how to help ESOL students in mainstream courses. Finally, all faculty members have access to IEP (Individualized Education Plan) for each ESOL student.

According to Sarah, the ELLs in Beaufort County are successful because she has "focused on training the mainstream teachers and administrators. This way all teachers, not only the ESOL teachers, see themselves as language teachers”. Her rationale for this approach was based on the fact that the students spend most of their time with mainstream teachers. Sarah continued to say "the ESOL teachers area already experts in teaching language; therefore, their role should focus more on intervention and training those without ESOL experience”. This is also why teachers are now required to obtain their ESOL endorsements in order to work in Beaufort County, South Carolina. Finally, Sarah says the last recommendation she has for other school systems is "get the parents involved. If there are parental outreach programs and the parents are knowledgeable about how to help their children in school, this transfers into student achievement”. 
Table 24. Percent of LEP students proficient on state assessments in Beaufort County, South Carolina before Sarah Owen hired as ESOL Coordinator vs. after she was hired and percentage change since 2005.

\begin{tabular}{|l|l|l|l|}
\hline Assessment & $\begin{array}{l}\text { Beaufort County, } \\
\text { South Carolina in } \\
\mathbf{2 0 0 5}\end{array}$ & $\begin{array}{l}\text { Beaufort County, } \\
\text { South } \\
\text { Carolina in 2012 }\end{array}$ & $\begin{array}{l}\text { \% Change from } \\
\mathbf{2 0 0 5}-\mathbf{2 0 1 2}\end{array}$ \\
\hline $4^{\text {th }}$ Grade Reading & $33.3 \%$ & $64 \%$ & $92.2 \%$ \\
\hline $4^{\text {th }}$ Grade Math & $41.3 \%$ & $72.8 \%$ & $76.3 \%$ \\
\hline $8^{\text {th }}$ Grade Reading & $12.2 \%$ & $48.3 \%$ & $295.9 \%$ \\
\hline $8^{\text {th }}$ Grade Math & $14.1 \%$ & $48 \%$ & $240.0 \%$ \\
\hline $\begin{array}{l}\text { High School } \\
\text { Assessment Program } \\
\text { (HSAP) }\end{array}$ & $36.0 \%$ & $87.3 \%$ & $142.5 \%$ \\
\hline
\end{tabular}

\section{Obstacles students confront}

In Chapter II of the study, the review of literature discussed some of the issues and obstacles that ESOL students confront in U.S. schools. During the interview, I asked Sarah about the obstacles that Beaufort County's ELLs face to see if there were any similarities. According to Mrs. Owen, the most difficult issue that the ESL students in Beaufort County face is the fact that

many of them are in the United States illegally. While in high school, many of the students participate in the dual-enrollment program. This program allows the students to take college courses at night and earn college credits. The ESL students prefer this option because the college will not verify their Social Security Number (SSN) while they are dual enrolled. After they graduate, they continue to take college courses until the school realizes they are in the country illegally.

The Ace Vocational high school in Beaufort County is a vocational high school that allows students to graduate with a high school diploma and a vocational skill. This school used to have a very large ESOL student population; however, the majority of these students have fallen victim to Beaufort County's anti-immigrant sentiment. A recent newspaper article printed in the Beaufort Gazette stated that all students must have a verifiable SSN to enroll or continue in Beaufort County schools. According to Sarah, this 
article has caused many negative consequences on the students as "only 2 ESOL students remained in the Ace school. The others have stopped attending for fear of being discovered, arrested, and deported”.

The final difficulty ESOL students face in Beaufort County is negative teacher attitudes. Many teachers have been resistant to the changing student population. One teacher told Sarah, “This is America. They should learn English”. Sarah also says that many teachers "look down upon the ESOL students and treat them as special education or special needs students”. Finally, many teachers are bitter about the large number of ESL students that have entered the school system due to school overcrowding and AYP failure. As an example, Sarah reported that Bluffton Elementary school is currently housing 600 more students than what the school was designed for. In addition to not having sufficient space for the students, many teachers have negative attitudes toward the ESOL students because "the teachers blame them for their school not making AYP”. The teachers believe their respective schools do not make AYP due to ESOL students taking the PACT without adequate language skills to pass the exam. Since the ESOL students have recently performed so well on standardized tests, I asked Sarah if she had seen a change in teacher attitude as a result. Sarah reported that

teacher attitude from the beginning was generally very positive. The teachers were concerned about the students and wanted to know how to help them. There was only one teacher who was outwardly negative directly to me. The biggest problems come from the teachers in schools that do not make AYP, but the teacher outlook does improve when teachers feel prepared to teach our ESOL students and the students do well. 


\section{ESL Lead Teachers}

Presented below are the summarized results from the interviews with 4 of Beaufort County's lead ESL teachers. Mary has worked for the Beaufort County School System for 13 years and has held ESL certification for 7. Rebeca has worked for BCSD for 12 years and has been ESL certified since 1998. Olivia has worked in Beaufort for 29 years and has held ESL certification for 15 years. Teresa has been with the county for 21 years and has taught ESL for 7 years. The results of the ESL teacher interviews are presented

following the candidates for examination from the conceptual framework and the emerging research questions. The teachers' responses center on the following themes: Policy (POL), Leadership (LDR), Teacher Training (TT), teacher attitude, why Beaufort

County is successful with ELLs, and the teachers' advice for other school systems.

Table 25. ESL Lead Teacher Demographics

\begin{tabular}{|l|l|l|l|}
\hline Teacher & $\begin{array}{l}\text { Years with } \\
\text { Beaufort County }\end{array}$ & $\begin{array}{l}\text { Years with ESOL } \\
\text { Certification }\end{array}$ & Level Taught \\
\hline Mary & 13 & 7 & Elementary \\
\hline Rebeca & 12 & 16 & Middle \\
\hline Olivia & 29 & 15 & Elementary \\
\hline Teresa & 31 & 7 & High School \\
\hline
\end{tabular}

ESL Teachers' Responses on Policy and Leadership

The responses from the 4 ESL lead teachers were very encouraging. All four of the participants spoke about how changes in ESL policy and leadership under Sarah Owen had brought about positive changes in the other teachers' regard for ESOL, in student achievement, and even in the physical space and personnel that ESOL classes were allotted. Beginning with a top down approach, Rebeca reported that the district coordinator alleviated a large amount of strain on the ESOL program and teachers by, 
counting the number of ESOL students and hiring the amount of ESOL teachers needed at the various schools in the district. This assisted the ESOL students and the regular classroom teachers. This gave us [ESOL lead teachers] more time to meet often with the "Response to Intervention" team members. We discuss the particular needs of students who are ESOL and the mainstream students. Hiring the extra ESOL teachers gave us the time we needed to try hard to meet the ELL student needs.

Mary echoed Rebeca's sentiments about the importance of having sufficient ESOL staff in the schools. Mary’s school now has 3 full-time ESOL teachers where she had previously been the only one. As a result, Mary reports that,

this is the first year that we have been able to schedule time to meet with teachers during grade level meetings and also to monitor our students who are "mainstreamed with accommodations." We are actually able to have a dialogue with classroom teachers about the ESOL students and their progress. Now we have the time and the people we need to provide suggestions for modifying instruction and additional support for the teachers.

Other important policies implemented by the ESOL leadership of Beaufort County helped to improve the prestige of the program in the eyes of the other teachers. Mary said she felt that the ESOL program began to gain more respect in the eyes of her colleagues when the principal "gave us [ESOL teachers] time to speak at faculty meetings and address the entire faculty at once.” Rebeca shared the same idea by saying that speaking at faculty meetings let everyone in her school know "ESOL is taken very seriously and supported by the administration. That way, all teachers respect and understand fully what ESOL is and what we do”. The final step in process involved changing the physical space occupied in the schools by ESOL classrooms. Rebeca was very excited to report that ESOL teachers are now given "the same large classroom space as other teachers where what we used to have was minimal”. 
All of the teachers credited Sarah Owen for providing successful leadership during a major transition in student population. Rebeca stated that Mrs. Owen handled her job with "commitment and intelligence to adequately meet the needs of the student and the teachers while keeping up with state and federal laws for ELLs”. Olivia credited Sarah Owen for ensuring that all the schools had adequate ESOL staff and that the ESOL staff was "constantly growing as professionals and providing the training mainstream teachers needed to work with the large ESOL population”. Finally, all four of the teachers commented on the decision Mrs. Owen made to not have regular teachers conduct classes with ESOL students until they had received SIOP training. Content area classes were taught by subject area certified teachers with ESOL endorsement until all teachers had completed the SIOP training. Teresa commented on the effects of this leadership decision by stating,

something I feel the district leadership did well was to have all teachers SIOP trained, putting the responsibility on everyone that teaches the ELLs, not only the ESOL teachers. Sarah really pushed for this so teachers couldn't have the excuse anymore that they didn't know how to accommodate the students. Sarah didn't want the teachers to face a classroom full of ESOL student until they felt comfortable and prepared to work with them.

One of the final policy decisions made by Sarah Owen was to hold 3 mandated Parent Nights a year. Three of the four teachers also spoke on the benefits of having this contact with the parents. Mary said this was very important because "it lets the parents know what is happening with their child in school and how they can help”. Olivia also spoke about the Parental Nights by saying that "it helps the parents feel like they are an important part of the school and their child's education”. 
When Sarah Owen took over the coordinator position for Beaufort County, the program was modified in several steps. Once the district had hired the necessary personnel, increased the prestige of the ESOL program, provided the space adequate to meet the needs of such a large ESOL population, the focus shifted to teacher training and preparing the Beaufort County’s mainstream teachers and administrators to work with the ELLs.

\section{ESL Teachers’ Responses on Teacher Training}

This question, along with the question on advice for other schools systems trying to accommodate large ESL populations, received the most response from the teachers. All 4 of the teachers mentioned that $\operatorname{SIOP}^{15}$ (Sheltered Individualized Observational Protocol) training was provided for all teachers in their schools. Additionally, all 4 teachers commented on the different reactions and attitudes to the SIOP training conducted in the schools. Mary and Olivia told me that all teachers in their schools were required to complete the SIOP training because of the large ESL population. Rebeca stated that "there have been more strict requirements for mainstream teachers, but the SIOP instructional method is not being required for all teachers in the schools; it depends on the number of ESL students in the school”.

Another interesting point that the ESL lead teachers told me about with regards to teacher training was the response towards SIOP training. Rebeca, Olivia, and Teresa reported that the teachers in their schools were responsive to the SIOP training and like the fact that "it is useful with all students" through all of the modalities. Rebeca expanded

\footnotetext{
${ }^{15}$ SIOP is a validated, research -based instructional model found to be effective with ELLs that is based on a total of 8 components. Those 8 components include lesson preparation, building background, comprehensible input, strategies, interaction, practice/application, lesson delivery, review \& assessment (Center for Applied Linguistics, 2014).
} 
her response to include that "SIOP opened the eyes of the mainstream teachers to what ESOL is and does, and all that is going on with a second language learner”. Teresa added that the mainstream teachers in her school "really appreciated what SIOP taught then about second language acquisition and curriculum modification”. When talking about SIOP training in her school, Mary said the teachers had "mixed feelings". She continued to say that,

most teachers welcomed more professional development in the areas involving how to best work with ESOL students without having to take a class, but the teachers were afraid that the accommodations for the ESOL students would require more work

Mary also talked about the importance of having a good instructor for the training. She said,

when SIOP training was first introduced in our district, the instructor was fabulous. The presentation dealt with cultural differences and the fact that teachers need to learn to appreciate cultural differences when working with students of other backgrounds.

Teresa also shared Mary's opinion on the importance of quality professional development trainers with the following example,

As with any Professional Development (PD) opportunity, the instructors can make the difference between a successful PD experience and one that is not, so I would highly recommend getting the best possible instructors to do training. In my district, the same PD opportunity was offered for two consecutive years but with different instructors. The first was not successful, and teachers were not satisfied with the experience. The following PD opportunity was extremely beneficial to teachers, and they felt they were better equipped to work with our ELLs after completing the workshop.

In addition to the SIOP training provided by the Beaufort County school district, the ESL lead teachers themselves are also responsible for provided on-site training for the mainstream teachers. Rebeca explained, 
at the beginning of each school year, we (ESOL lead teachers) provide mini workshops about what ESOL is and how to modify assignments for the second language learners. We also offered these trainings to the teacher assistants since so many of them worked directly with our ELL learners concerning literacy skills.

Teresa talked about the training given at the onset of each school year by saying,

we do an initial presentation at the beginning of the year to the faculty explaining the ESOL program at our school (how students qualify, the different services offered at the different levels, mainstream teachers' responsibilities to modify curriculum and assessments, definition of ESOL levels and suggestions for modifications/accommodations/assessments at each level, important forms, etc).

Olivia also spoke on the importance of this same initial yearly training for all teachers in

her school. She reported that this presentation "helped to orient the teachers on what to do and where to go if they need help with their ESOL kids”. Teresa continued to explain that having the ESOL teachers themselves conduct these training sessions in her school is "very successful” because

The ESOL teachers were all mainstream classroom teachers before going into ESOL. We understand what it is like to have a class of 25 students with different academic needs. Our goal is to show concrete examples of ways to modify instruction that won't take unreasonable amounts of time. We create our trainings with these things in mind. Our goal is for teachers to be able to go back into their classrooms equipped with strategies to help them instruct ESOL students. We try not to overwhelm teachers with too much information at one time. We also provide professional development during teachers' planning periods to show examples of how to modify curriculum in different disciplines.

In addition to the SIOP training, which the teachers told me is offered at various times throughout the school year and during the summer, the teachers also stressed the importance of other forms of training. Teresa and Mary spoke on professional development courses (they did not specify which courses) offered by the county that counted as graduate credit towards ESOL endorsement. Two of the teachers, Mary and 
Olivia, recommended Gateway ${ }^{16}$ classes and Spanish for School Personnel for all teachers, administrators, and staff members who work with ELLs and their families.

When I asked the ESL lead teachers about whether or not the mainstream teachers utilized the accommodations they learned in the various training sessions, all of the teachers told me they have seen the mainstream teachers use the recommended ESOL accommodations. The only bittersweet example on the topic was given my Mary when she explained,

I have been in classrooms where teachers are paying close attention to how they deliver the information. They spend time on vocabulary, making instruction relevant and building background, but some teachers do not modify instruction. They give reading assignments and worksheets to all students. They do not partner ESOL students with other students or use any of the ESOL strategies that work well.

However, the other three ESL lead teachers’ comments were similar to Rebeca’s when she stated "the teachers in my school do a wonderful job of modifying instruction". Teresa also reported on additional support that is offered to the mainstream teachers. Every teacher in the district receives a manual compiled by Sarah Owen that contains helpful information, tips, and strategies for the mainstream teachers who have ESOL students in their classes. Additionally, each ESOL department in the various schools maintains content materials to support grade level standards across various subject areas. These materials are kept on site in the schools and available for the teachers to checkout as needed.

\footnotetext{
${ }^{16}$ Gateway was a program that Beaufort County used at the beginning of its ESOL population explosion. It was a program for newcomers to the country who had little or no English language skills. The ESOL students were taught in self-contained classrooms with an ESOL teacher all day. The students were taught Basic Interpersonal Communication Skills (BICS) and then mainstreamed with accommodations when ready.
} 


\section{ESL Teachers’ Responses on Mainstream Teachers’ Attitudes}

When the ESL teachers were asked about mainstream teachers' attitudes about the

ESL population boom in Beaufort County schools, their answers were varied. Mary, Rebeca, and Teresa reported that the overall attitude toward the ESL population was initially very positive, but they began to change as the ELL population continued to explode. Teresa states that teachers were excited and "welcomed the diversity" to the classroom. However, many of them quickly become frustrated because, they were not trained to work with second language learners, especially students with little or no English. The new demands placed on the classroom teachers caused many to have negative feelings towards the ESOL population.

Only Olivia stated that the attitudes in her school were negative from the very beginning. She stated that the teachers in her school felt "lost and frustrated because they didn’t know what to do". She also attributes the negative attitudes to the fact that teachers "did not have the proper training in the mainstream classes or thought it was going to cause them to have to do a lot more work to accommodate them in their classes". Olivia best summarized what all the interviewees said about the mainstream teacher attitudes becoming positive again by stating

SIOP training made teachers more comfortable with teaching ELLs and making accommodations and modifications. When they saw that these trainings were useful and worked with the students, they began to feel more confident and better about having the ESOL students in their classes.

Why Beaufort County Schools are Successful with ELLs

When asked about why Beaufort County had been so successful with the ESOL population in the schools, the teachers attributed the success to a wide variety sources. However, all of the teachers had one commonality in their responses. They all spoke 
about the role of teacher training and collaboration between the ESOL and mainstream teachers with push-in classes ${ }^{17}$. Olivia reported that,

our ESOL team strives to target the individual needs of each ELL and customize our teaching strategies based on those needs. This plan along with working more closely with the regular classroom teachers helps us to bridge any learning gaps. Also, having ALL of the teachers in the schools SIOP trained and comfortable with modifying the curriculum when necessary have helped a great deal. We (the ESOL teachers) know what has worked best in the past and we use our expertise with the regular teachers as to what strategies/or models will provide the greatest success. We also work collaboratively with the regular teachers to monitor the progress of the students”.

Mary commented on the ESOL program becoming much more responsive to the needs of the increasing ESOL student population and the positive effects that responsiveness has had on students. She stated that,

it was clear that these students needed extra support. Our schools responded to that need through training and extra support. Our teachers were SIOP trained and the ESOL teachers were always on hand to give any added support. Giving the students all of this extra support helps them feel valued, welcomed, and comfortable. My ESOL students now feel comfortable enough to come during recess time and ask for my help when they don’t understand something.

When Rebeca spoke on why ELLs are successful she stated “communication and collaboration is a huge key to the success in Beaufort County and we are always trying to figure out what will work best.” However, she also added a different dimension to her answer when she said,

students entering the ESOL program, whether they are a newcomer or getting ready to leave our program, are met with high expectations to succeed. The ESOL staff and regular classroom teachers work closely together to customize a program that will challenge, but not overwhelm, the students.

\footnotetext{
${ }^{17}$ Push-in classes are collaborative mainstream classes in which ESOL students receive content area instruction from a mainstream teacher along with an in-classroom ESOL teacher to provide support for the ESOL students.
} 
Teresa continued Rebeca's idea and summarized all of the teachers' thought by stating

that

we are successful due to outstanding staff and well developed curriculum and system of delivery services. We have continuous support from well-trained, highly qualified teachers (ESOL and regular), school administrators, and the district coordinator. We have developed an integrated curriculum, hired and trained better teachers. We have provided enough instructional materials and professional development (which does involve a huge financial investment). In a nutshell, all school personnel are committed to the belief that ELLs can succeed.

Some of the other tools for success mentioned by the teachers included after school tutoring services that are open to all students, accepting cultural differences among the students, using technology to support classroom lessons.

ESL Teachers’ Responses on Advice for Other School Systems

The 4 ESL lead teachers from Beaufort County had many different suggestions for other schools systems trying to accommodate a large ESOL population. Due to several of the points being repeated throughout the 4 interviews, the responses to this question were compiled into the following list:

1) Hire an ESOL coordinator for the district;

2) Survey the teachers to see which ones already have experience working with ESOL students. Utilize these teachers to help the ESOL students until all of the other teachers are ESOL trained;

3) Have staff development days that focus exclusively on ELLs;

4) Allow teachers to visit other schools with successful ESL programs;

5) Hire a bilingual ESOL liaison in each school;

6) Provide Gateway Classes;

7) Have ESOL teachers pull-out students for English instruction and then push-in with the mainstream teachers for content area instruction; 
8) Have a wonderful parent/family relationship with the ELLs. We hold 3 parent nights a year with our parents and students to socialize and provide resources, information, and literacy tips to the families. This gives the families a real sense of involvement in their child's school. The parents feel accepted and understood. This is very important for the parents/family and the student;

9) Train all mainstream teachers in SIOP;

10) Pull-out the ESOL students and push-in with the mainstream teacher;

11) Train the office staff responsible for registering the ESOL students;

12) Offer additional ESOL training or certification classes at times convenient for the teachers (after school, weekends, summer, etc.);

13) Have the ESOL certified or endorsed teachers give the SIOP training for those teachers who do not have experience with LEP students;

14) Have an ESOL language lab with quality software (Rosetta Stone and Open Book to provide additional support to the students. The students utilize the lab daily and it counts towards their elective credits;

15) Have inclusion classes for higher level ESOL students who do not need sheltered instruction but still need daily ESOL support. We have done this for 3 years in my school, and it has been very successful. ESOL teachers push-in to mainstream English Language Arts classes. To ensure the success of this model, careful attention should be given to the level of ESOL training the mainstream teacher has, the selection of only the mainstream teachers who are willing to participate, and the careful pairing of ESOL and mainstream teachers. This is a great option to push the ESOL students into content classes because they have extra support from the ESOL teacher in the content areas where many students struggle.

\section{Mainstream Teachers}

The results reported below are from 6 mainstream teachers in the Beaufort County School District. The schools selected were recommended by Sarah Owen because of their large ESL student populations. The 6 participants were recommended by the school principal once he/she read the purpose of my study. Once the principals gave me the names of the teachers, I sent them an e-mail explaining the purpose of my study and the 
participants' rights. I also included a scanned copy of the letter signed by Sarah Owen giving me permission to conduct my research in the Beaufort County School District. I wanted the teachers to understand that participation was voluntarily, they could leave the study at any time, and that their identities would be kept anonymous. Four of the teachers told me that they "always" have large ESL populations in their classes while the other 2 "frequently" have ELLs in their classrooms. Five of the teachers do not hold ESL certification, but 1 teacher has earned it since coming to Beaufort County. Like the results from the ESL lead teachers, the information collected from these interviews will be presented using the 3 coding schemes of Teacher Training (TT), Teacher Attitude and Feedback, and Advice for Other School Systems. For this portion of the data collection, the coding schemes of Policy (POL) and Leadership (LDR) were eliminated simply because these teachers are not involved in the formation or execution of these two aspects of the ESL program in the BCSD. However, I was particularly interested in gaining insight in the area of Advice for Other School Systems with this group of teachers. The results presented below are based on the mainstream teachers' responses.

Table 26. Mainstream Teacher Demographics

\begin{tabular}{|l|l|l|}
\hline Teacher & Years with BCSD & Level Currently Taught \\
\hline Lucia & 7 & Elementary \\
\hline James & 8 & Middle \\
\hline Beth & 15 & Middle \\
\hline Marie & 14 & Elementary \\
\hline Charlotte & 27 & Elementary \\
\hline Alberto & 22 & High \\
\hline
\end{tabular}

\section{Mainstream Teachers' Responses on Teacher Training}

When speaking on the training the teachers had received and which trainings were most beneficial, all 6 of the mainstream teachers spoke on the benefits of SIOP. Marie 
reported that before the SIOP training she was very "hesitant and nervous" about working with the ELL population in her school that seemed "to explode from one day to the next". After receiving the SIOP training, Marie reported feeling "like I have a better idea what to do with the students. I found it to be very practical and helpful, even with my regular students”. Marie’s feelings were corroborated with the other teacher interviews as all of the other teachers reported that ESOL students were rarely or never lost in their classes after they began using the SIOP model.

The teachers mentioned a few other additional trainings that they had received as being very beneficial to them. Both James and Charlotte spoke of the ESL strategies and methods training offered by Sarah Owen. James particularly liked the fact that the trainings were offered on-site at his school. He said that,

having the training in my building before the school year began was great. It was convenient because I was not trying to balance all of the day to day demands of work along with squeezing in some other training or one other meeting during my already limited planning time. I was able to really concentrate on the training and get something out of it. I left Sarah's training with a plan for how to teach my ESOL students. I felt like Sarah really took time to consider the teachers' feelings and respected our time by holding the meeting before school started”.

Some of the other trainings the teachers mentioned included ESL Laws and Strategies, Spanish for Classroom Teachers, the training mandated by the county and the state, and the various training sessions offered by the ESL lead teachers in the schools. The final trainings recommended by Alberto were ongoing diversity training and cultural awareness workshop offered by the district.

When asked if the teachers utilized the training they have received, 5 of the teachers said that they and their colleagues frequently used ESL accommodations and 
strategies in their classes. Marie is the only teacher who said that she had not seen all of the teachers in her school utilizing the SIOP training they had received.

\section{Mainstream Teachers’ Responses on Teacher Attitude}

Out of the six teachers, half of them reported experiencing or being witness to negative teacher attitudes in their schools. Lucia told of one very poignant moment when she went to meet with another teacher about a group of ESL students the two teachers had in common. Lucia reported that in the course of the conversation, her colleague stated "I hate these students. They are the bane of my existence and they should learn English”. Lucia continued to stay that "this teachers is an exception in my school. Most of the teacher feedback about ESOL students is generally very positive. Many of the teachers and I like the diversity they bring to the classroom”. According to Marie, the negative attitudes she has seen in her school is linked to not using the SIOP training or ESL strategies and methodologies from the training sessions. Marie stated,

Some teachers go too fast and do not take time to check for comprehension. This causes frustration when students don't do well on the test and the teachers have to take time to go back over the material. Teachers also get frustrated when they don't feel they have adequate time to cover all of the standards for a class because they have to take time out from instruction because of language issues. They need to take time out to check for comprehension of basic vocabulary because words that a native English speaker may easily understand can be meaningless to an LEP student.

The final comments on negative teacher attitude came from Charlotte. She reported that "only a few of the teachers in my school don't like having the ESL students. They think they require too much individual attention and take away from the rest of the class”.

Beth spoke very positively of the ESL students in her class. She stated that the

ESL students "are very motivated and that keeps me motivated. I use as many hands-on 
activities as possible and I have a wonderful time with these students”. James spoke about the SIOP training and ESOL teachers in his school being the reason for the positive teacher attitudes in his school. James said that,

The teachers in my school liked the ESOL students and were very receptive to them. They are more comfortable with the students now that they know how to make accommodations for them. The ESOL teachers in my school have been a wonderful resource for the teachers. They are always willing to help out when we need it. It is reassuring to know they have our backs in case we have questions or need extra help.

When commenting on teacher attitude in his school, Alberto very plainly stated that

I am really surprised by the number ESOL kids we have in Beaufort County now, but I really like working with this group of kids. I like the perspective and cultural diversity they bring to the classroom.

\section{Mainstream Teachers' Responses on Difficulties Accommodating a Large ESOL Population}

When asked about what difficulties the mainstream teachers confronted when accommodating a large ESOL population, the teachers mentioned several different issues. Lucia said that there were four obstacles that she confronted with her ESOL students. Those four obstacles were "inconsistent practices among teachers, lack of peer acceptance, lack of parental communication, and only being able to speak minimal Spanish’. James also reiterated Lucia’s concerns by stating that he “can’t communicate with the parents because I don’t speak the language. I also can’t communicate with my very low-level students, so sometimes keeping their attention and them motivated is very hard”. Beth reported that accommodating the ESOL students in her school had gone very smoothly thanks to the ESOL lead teachers on staff. She said “I don't have many problems because of our ESL teachers. They are fabulous and a wonderful resource when 
we do have any problems with the students”. The issues in Marie’s school centered

around utilizing the training she has received and the language barrier. She stated,

I hate coming up with so many ideas for ways of differentiating instruction. It becomes tiresome and 1 or 2 students become the focus of the class. It is also difficult to differentiate because of our large class sizes. I also get frustrated because of the language barrier. I can't communicate with the low students, I can't communicate with the parents, and the parents can't help with assignments.

Marie continued to talk about the other difficulties she faced accommodating the ESL

population while still trying to meet her job expectations. She reported that

We are held accountable for these students to have met the content standards. This is impossible with the resources we have! We would need the resources to provide $100 \%$ one-on-one instruction in order to provide students with both a total language transformation and the complete ownership of the content. We also lack resources, funding, and staff. Our ESL population is huge and they receive ESOL services 5 days a week, but only for only 45 minutes a day. They still seem to be getting lost, especially if the teacher doesn't differentiate instruction or use the ESOL strategies. I am not sure what exactly needs to be done, but some more changes need to be made.

Charlotte also stated that the language barrier is also her biggest issues. She reported that,

I use my limited language skills, sign language, or body language to communicate with the students. This also comes into effect with the parents. I would like to do more home visits and have more communication with the parents, but I don't speak Spanish, so I can't”.

Alberto said the largest issue he had seen in his school was with "the teachers who don't know what to do with the students and the training they have received. They get frustrated and come to me to vent”. The second issue Alberto commented on was the prejudices of the teachers. He reported that "the teachers often make stereotypical comments about the students and these teachers have lower expectations for the students because of their prejudices”. 
Recommendations for Other School Systems on How to Successfully Accommodate a Large ESOL Population

When interviewing the mainstream teachers about their recommendations for other schools, something very interesting happened with their responses. All of the teachers gave almost identical recommendations for other school systems. As a result, the teachers' responses were compiled into the following list:

1) Hire an ESOL coordinator for the district and have sufficient ESOL teachers for each school;

2) Have all teachers SIOP trained;

3) Offer language classes to all teachers and school personnel so at least basic communication with parents and low-level students is possible;

4) Having ESOL teachers teach content area classes while other teachers are being trained and transitioning is a fabulous idea;

5) Diversity training for all teachers and school personnel;

6) Use the ESOL teachers to train those without ESOL training;

7) Have the ESOL coordinator offer training to all teachers in the district;

8) Provide teachers with a quick-reference guide for ESOL strategies and tips that teachers can reference in a hurry when preparing lessons;

9) Offer continuous SIOP training and professional development at times that are convenient for the teachers like weekends, summer vacations, or teacher planning time before the beginning of the school year;

10) Have smaller class sizes so that teachers have adequate time to focus on the needs of ESOL students;

11) Properly fund and staff the ESOL program so all teachers understand it is important and necessary;

12) Hire a bilingual liaison in each school who can help teachers and students communicate; 
13) More Parent Nights so parents can be involved in their child's education.

\section{Summary}

This chapter presented the results of my interview with Sarah Owen. During the interview, I learned about her education and previous experience teaching ESOL. She also told me about what Beaufort County’s ESOL program was like in 2001 when it first began responding to the ESL population boom. The county's response then changed again in 2006 due to meteoric rise in the number of ELLs in schools. Sarah also told me about the changes she has implemented in Beaufort County's ESOL program, why she thinks ELLs are successful in schools, and what obstacles the students face. The interviews with the ESL lead teachers focused primarily on their experiences in the areas of ESL policy, ESL leadership, and teacher training. The secondary themes that came out of the interviews included teacher attitude and feedback, their advice for other schools systems confronting the issue of accommodating a rapidly growing ESL student population, and why they thought the Beaufort County school district has been successful with ELLs. The third portion of this chapter reported the results of interviews from 6 mainstream teachers in the Beaufort County School System. Their interviews also focused on teacher training, teacher attitudes, issues the teachers confront when working with large ESL populations, and their advice for other school systems confronting the same issues. 


\section{CHAPTER V}

\section{DISCUSSION}

This research studied focused on the Beaufort County, South Carolina school system and the recent success of the ESOL population by interviewing the teachers responsible for educating these students. This chapter presents the discussion of the results from the interviews with Sarah Owen, the ESL lead teachers, and the mainstream teachers. The discussion will focus on what the Beaufort County School System has implemented with respect to ESL leadership, ESL policy, teacher training, and advice for other school systems. Additionally, the role of critical pedagogy and critical literacy in Beaufort County's ESOL population will be discussed. Finally, this chapter will also present a top-down model for ESL student success that can be replicated in other school systems based on the feedback from the interviews with Sarah Owen and the Beaufort County teachers.

\section{Analysis of Results Based on Conceptual Framework}

The conceptual framework for this chapter was built on the idea that ESL leadership, policy, and teacher training are all necessary elements in order for ESOL student to be successful in U.S. schools. The conceptual framework was based on historical trends as well as federal laws and policies for students. The framework represents what has happened and what the current U.S. policies are in order to obtain the political definition of 'success' in U.S. classrooms. 
Figure 12. Conceptual Framework for ELLs and Mainstream Historical Trends
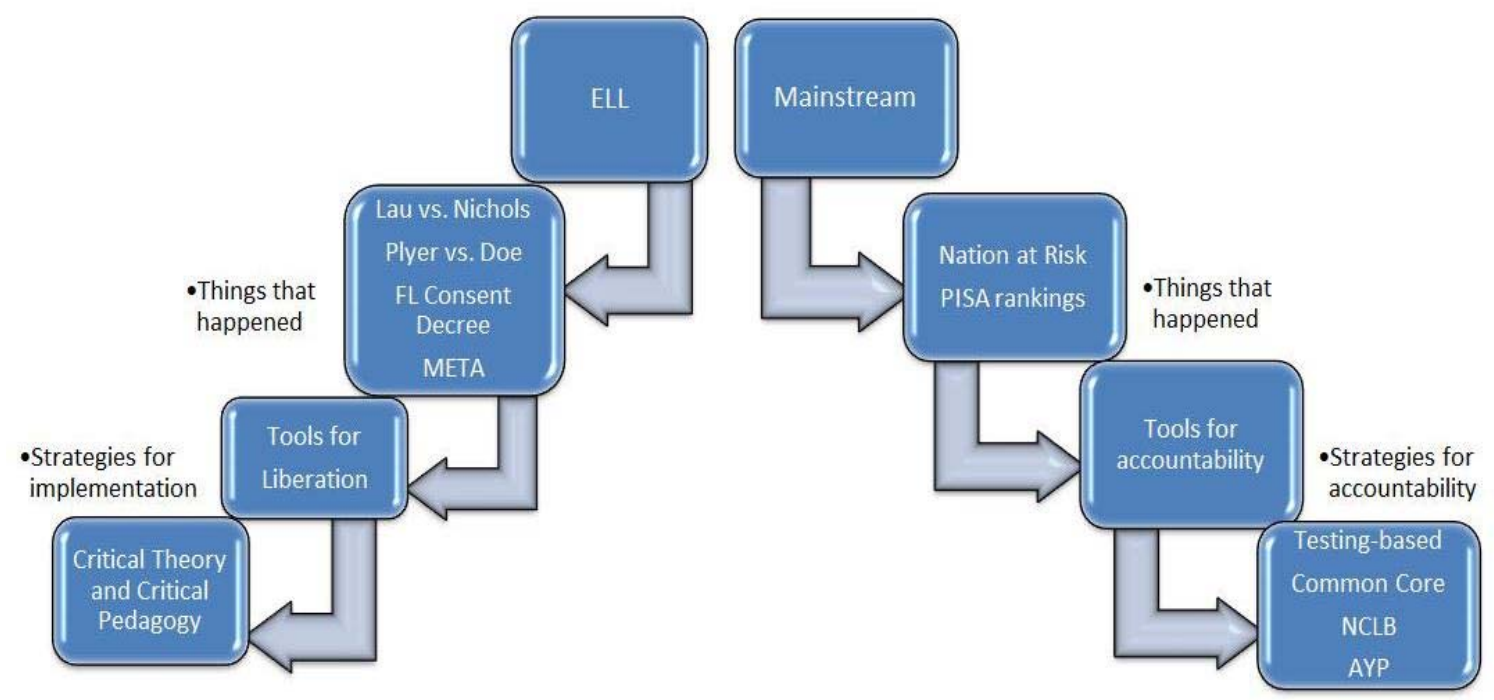

ESL Leadership and Policy

The success of the Beaufort County ESL population has come under the administration of Sarah Owen as the ESL, Gifted, and World Languages Coordinator. The four requirements for successful educational leaders as outlined by Bennis and Nanus (1997) are all fulfilled under Sarah Owen. She has shown "attention through vision” by reforming the Beaufort County ESOL program based on the needs of each individual school. She has not utilized one uniform ESOL approach or strategy for the entire county. The ESOL approaches, strategies, and methodologies are determined based on the ESOL population of the respective school. Therefore, each school has a tailormade ESOL program rather than a generic, county-wide program. The second strategy of "meaning through communication" has taken place in the training workshops she has personally conducted with the teachers. This allowed Ms. Owen a forum in which she could directly communicate with and model for the teachers what they should be doing in 
the classroom in order to help the ESOL students. The third quality of a good leader, “trust through positioning”, is met through the changing role of her ESOL lead-teachers in the schools. Ms. Owen was very strategic in utilizing the ESL teachers already present in schools to provide additional training to those who had no or little experience working with ESOL students. Secondly, these ESOL lead-teachers served as a point of contact if the mainstream teachers encountered issues or later had questions executing the training they had received. This helped to establish a position of trust between the teachers and the ESOL department because the teachers were not left to fend for themselves with the ESOL students after a whirlwind, initial training session. They were given an on-site support system to help them throughout the transition. Finally, teacher training has been one of the principle concentrations. She wanted teachers to have the strategies, approaches, and methodologies necessary to teach ESL students and native speakers in the same mainstream classrooms. As a result, all Beaufort County teachers were required to obtain their ESOL endorsement if they were not ESOL certified. This has helped to meet the final requirement of "development of self”. The process of earning the ESOL endorsement allowed teachers to further their education and has given them more experience in a different branch of the field of Education. This has helped to foster one aspect of the teachers' "development of self" with respect to their professional lives (Murray, 1997, p 15).

Ms. Owen was also very strategic in ensuring that the ESL parents were involved in the school. By mandating 3 Parent Nights a year that are exclusively for the ESOL parents, the parents learn how to help their child in school. Furthermore, this was Ms. Owen's one piece of advice to other school systems trying to accommodate a large ESL 
population, "get the parents involved. If there are parental outreach programs and the parents are knowledgeable about how to help their children in school, this transfers into student achievement”.

Finally, Ms. Owen has met all three commonalities of the schools that experienced gains in ESL achievement as presented by the 2009 study from Council of the Great City Schools. She changed the role played by the ESOL and mainstream teachers responsible for educating the English language learners. The ESOL teachers are no longer the sole source of language instruction for the students. Their role has grown to include more focus on training the mainstream teachers and on working as interventionists and advocates for the students. As a result, this has placed the responsibility of teaching language and content on all teachers, not only the ESOL teachers. As Ms. Owen stated in her interview "the ESOL teachers area already experts in teaching language; therefore, their role should focus more on intervention and training those without ESOL experience”. This idea was supported by one of the ESOL lead teachers, Olivia, when she said that the new duties under Sarah Owen kept her and the other ESOL teachers "constantly growing as professionals and providing the training mainstream teachers needed to work with the large ESOL population”. By making this change and taking this position on ESOL teachers, Ms. Owen and the ESOL lead teachers demonstrated the first two commonalities from the Council study (2009): "shared vision for reform” and "leadership and advocacy on behalf of ELLs” (p. 2). ESOL teachers were no longer given the sole responsibility of teaching language. They became the teacher trainers under Ms. Owen’s administration. 
With respect to leadership, school administrators have shown that ESOL is important through various means such giving the ESOL teachers time to speak at faculty meetings and allowing them to conduct training workshops for all school personnel. Secondly, the ESOL teachers are given time to meet with mainstream teachers during grade level meetings to discuss student needs. In addition to these meeting times, ESOL teachers also hold workshops for their entire schools to inform them about the paperwork, processes, purposes, and functions of ESOL in schools. The focus on teacher training has not been limited to only the teachers. School administrators have followed the tone set by ESOL leadership by taking additional language training classes in order to communicate more efficiently with the students and their parents. Finally, ESOL classrooms are being given more classroom space in the schools. These actions by the leadership relay the message that ESOL is a subject area to be taken seriously and where additional training is necessary and valuable for all school personnel. These steps also meet the final commonality presented in the Council study (2009): "empowerment of the ELL Office" (p. 2). Once the administration had completed the aforementioned steps, the ESOL program grew in visibility, prestige, and importance in the Beaufort County schools. The reforms made by Sarah Owen as the ESOL District Coordinator not only affirmed the recommendations of the Council of Great City Schools, but they also supported 3 of the findings of Garcia's (1992) study that presented 8 effective strategies for ELLs. Garcia supported “teachers advocate for students, principals support ESL teachers, and ESL parents involved in school.” Garcia's (1992) other 5 recommendations were also present in the Beaufort County schools; however, they will be discussed later in the chapter as they are related to pedagogy rather than leadership and policy. 


\section{Teacher Training and Feedback}

The interviews with both groups of teachers, and the mainstream teachers in particular, highlighted the changing attitudes of mainstream teachers in Beaufort County as the ESOL population exploded. While this new group of students was initially a cause for excitement because of the diversity they brought to the classroom, this excitement soon turned into fear as teachers thought they lacked the tools necessary to educate the students with limited English proficiency. This worry was alleviated through additional teacher training. One recurring theme that was praised by both groups of teachers was the benefit of SIOP training and how it was conducted. Several of the teachers said they found it to be a valuable teaching methodology with both ELLs and native speakers alike, when the training was conducted with a qualified instructor. Having the training conducted by the ESOL teachers already present in the schools gave mainstream teachers the opportunity to resolve issues with ESOL students or have questions answered immediately by experienced and knowledgeable on-site personnel. An additional benefit of having the ESOL training conducted by the ESOL teachers is the fact that they understood the demands of the classroom with respect to time limitations and the curricular standards. This allowed the ESOL teachers to focus the teacher training sessions on ESOL strategies, methodologies, and modifications that worked well and that teachers could easily utilize given the time and curricular restraints. Finally the ESL leadership decided that mainstream teachers would not be given classes with ELLs until they had the training necessary on how to modify classroom instruction for this group of students. ESOL teachers who were qualified in the various subject areas taught these classes until more teachers were prepared to take on the task. 
According to the interviews with both groups of teachers, these approaches seem to have been successful. Most teachers in Beaufort County report that they are generally very happy with having ELLs in their classrooms. As the ones responsible for imparting the ESOL training, the ESOL teachers also report that they are very happy with the types of modifications they see being made in the classrooms. As a result of the various trainings, the mainstream teachers reported that they now feel adequately prepared and comfortable instructing ELLs. Having this training and feeling prepared to instruct this group of students has helped to improve teacher attitudes towards ESOL students. Finally, both groups concurred that it is only isolated individuals in the schools who do not modify instruction for the ESOL students or outwardly show negative attitudes towards them.

Even though both groups credit SIOP training as being very successful with ESOL students, there was a noted difference in the responses between the ESOL teachers and the mainstream teachers with respect to this topic. The ESOL teachers spoke in great detail about the SIOP training, other professional development workshop they give, additional training and professional development workshops given from outside trainers, and the resources available in schools for all teachers to use when instructing ESOL students. However, the one of the mainstream teachers interviewed stated that many teachers in the school were not sure of how to utilize the training they had received.

All of the previously mentioned events in the Beaufort County school system as reported by the teachers show evidence of the implementation of Garcia's (1992) remaining 5 strategies that work well for ELLs (pp. 3-4). The first strategy, high levels of communication between students and teachers, was supported by Mary and the 
illustration that her ESOL students now "feel comfortable enough to come during recess time and ask for my help when they don’t understand something." This indicated that Mary has very good rapport with her students and they are no longer afraid or embarrassed to ask for extra help when needed. Integration of language skills into subject area instruction, themed instruction, collaborative group learning are all part of the SIOP approach to language instruction if utilized correctly. Most of the teachers reported that SIOP was widely utilized in the Beaufort County schools with the exception of only a few teachers. Finally, James, Alberto, and Teresa stated that the students' native language of Spanish was allowed in their classrooms. James and Teresa mentioned that teachers sometimes came to them for help due to the fact that they spoke Spanish. Alberto said that he "sometimes relied on the higher-level students in class to translate for lower-level students when they didn’t understand”.

In 2009, the Council for Great City Schools reported on 8 promising practices for ESOL programs that were posting gains in student achievement. Four of the 8 promising practices that related to the scope of this study were comprehensive planning and adoption of language development strategies for ELLs, extensive and continuous support for implementation, high quality, relevant professional development, and reallocation and strategic use of ESL funds (pp. 2-3). All four of these promising practices have been evidenced in the Beaufort County school system. Under the leadership of Sarah Owen, comprehensive planning and adoption of language development strategies for ELLs was executed through having all teachers SIOP trained and ESOL endorsed. The first step of the process, SIOP training for all teachers, gave a uniform approach for all teachers to adopt when working with ELLs. Sarah Owen's strategy for developing ELL strategies 
and planning were made even more complete by having all teachers ESOL endorsed. Earning this endorsement helped deepen the skill set the teachers had begun with the SIOP training. It gave all of the teachers of Beaufort County equal background knowledge and access to information on how to the ELLs in their classrooms. The second promising practice, continuous and extensive support for implementation, has happened throughout Sarah Owen's leadership and it is connected to the third promising practice of high quality, relevant professional development. All of the mainstream teachers interviewed spoke of the training they had received while the ESOL teachers focused more on the training sessions they had given. These sessions were offered at continuously at various times in the school year and during breaks, which was very convenient for the teachers' schedules. The final promising practice that was evident in the Beaufort County schools was reallocation and strategic use of ESL funds. Ms. Owen used ESL funds to buy computer software such as Rosetta Stone and Open Book to help support the students' language skills and for an ESL computer lab. This was a very intelligent use of ESL funds because it provided students with a technology-based component to help further their language skills while gaining elective credits at the same time.

\section{Difficulties Teachers Confront}

When addressing the topic of difficulties that teachers confront when working with Beaufort County's large ESL population, one of the themes mentioned several times by the mainstream teachers was the language barrier. This barrier exists not only between the teachers and students, but also between the teachers and parents. This issue came into sharp fruition when Charlotte reported, 
I use my limited language skills, sign language, or body language to communicate with the students. This also comes into effect with the parents. I would like to do more home visits and have more communication with the parents, but I don't speak Spanish, so I can't.

The teachers and school administrators of Beaufort County have taken basic classes in Spanish for school personnel, but the teachers do wish they had more Spanish skills in order to communicate with lower-level students and to have the potential to communicate with the parents.

Another theme mentioned by the teachers with respect to the difficulties they confront was lack of teacher training and inconsistent practices among teachers. While the teachers interviewed praised the SIOP method and how it has helped both ESOL and native speakers alike, the teachers did report that not all of the teachers use this method with the students. Even teachers who reported utilizing the SIOP training said that utilizing so many methods of differentiating instruction became time consuming and frustrating. Additionally, teachers reported being frustrated with the time demands of teaching the required curriculum and content and not having enough time for the additional ESOL instruction the students need. Marie voiced all of these teachers' concerns when she gave an example based on her own frustrations,

I hate coming up with so many ideas for ways of differentiating instruction. It becomes tiresome and 1 or 2 students become the focus of the class. It is also difficult to differentiate because of our large class sizes. I also get frustrated because of the language barrier. I can't communicate with the low students, I can't communicate with the parents, and the parents can't help with assignments. We are held accountable for these students to have met the content standards. This is impossible with the resources we have! We would need the resources to provide $100 \%$ one-on-one instruction in order to provide students with both a total language transformation and the complete ownership of the content. We also lack resources, funding, and staff. Our ESL population is huge and they receive ESOL services 5 days a week, but only for only 45 minutes a day. They still seem to be getting lost, especially if the teacher doesn't differentiate instruction or use the 
ESOL strategies. I am not sure what exactly needs to be done, but some more changes need to be made

Why Beaufort County is successful with ESOL students

When the teachers responded to why they think Beaufort County has posted such great success with ESOL students, the teachers offered several reasons such as teacher training, collaboration, high student expectations, and acceptance of cultural differences. Training all of the teachers in SIOP helped to ensure that all teachers were well-qualified and had the skills necessary to teach the ESOL students. This step went hand-in-hand with the collaboration necessary between the mainstream and ESOL teachers to provide the appropriate support and interventions for the ESOL students. A few of the teachers interviewed spoke of the fact that they are always working together, communicating, and trying to decide what will work best for the students. They try to provide customized instruction based on the needs of the individual student. This communication and support for the students not only takes place during school hours, but also afterwards. All students in Beaufort County are offered free after school tutoring, if necessary, from teachers and members of the community. Olivia reported that ESOL students are successful in Beaufort County because,

our ESOL team strives to target the individual needs of each ELL and customize our teaching strategies based on those needs. This plan along with working more closely with the regular classroom teachers helps us to bridge any learning gaps. Also, having ALL of the teachers in the schools SIOP trained and comfortable with modifying the curriculum when necessary have helped a great deal. We (the ESOL teachers) know what has worked best in the past and we use our expertise with the regular teachers as to what strategies/or models will provide the greatest success. We also work collaboratively with the regular teachers to monitor the progress of the students. 
One of the other reasons given for the ESOL students' success has been teacher attitude and high teacher expectations. The teachers reported that lack of language skills does not excuse the students from performing well. Regardless of a student's English proficiency, the teachers have high expectations from the moment the students enter the classroom. These high expectations are coupled with an attitude that welcomes the students to the class and celebrates the cultural diversity that they bring. Rebeca summarized her opinion on what works well by stating "communication and collaboration is a huge key to the success in Beaufort County and we are always trying to figure out what will work best.” Therefore, trying to do what is best for the ESOL students in Beaufort County is an on-going process based on teacher communication and high expectations for student achievement. Recommendations for other school systems

Both the ESL and the mainstream teachers had many pieces of advice to offer other school systems confronting the issue of successfully accommodating a large ESOL student population. The ESOL teachers recommended making sure that all teachers received high-quality training in the SIOP model of instruction and other professional development opportunities that focus on ESOL student education. These methods of instruction should vary based on the English language proficiency level of the student. The teachers recommend the highly structured SIOP model for lower proficiency students and gateway or push-in model/inclusion classes for those with higher proficiency levels. For all levels of language proficiency, the materials should have technology-supported components that offer additional language support for the students. 
The ESOL teachers in the schools should also offer on-site professional development because they understand the demands placed on teachers in the individual schools. The ESOL teachers should also serve in the capacity as resource for mainstream teachers on how to best teach ESOL students. Other school systems that have experienced a large expansion in ESOL student population should also be used as a resource to aid in the accommodation process. This could include visiting the schools, allowing teachers from these districts to come and speak, and modeling the programs that have already been successful with ELLs.

Both the mainstream and the ESOL teachers recommended having an ESOL Coordinator for the schools system and ESOL liaisons in each school. These are important contact personnel for the teachers in each school. The ESOL liaison is particularly important for communication between the schools and the parents. With respect to the parents, the teachers also recommend ESOL Parent Nights at the schools. There are three mandated Parent Nights a year in Beaufort County, and the teachers see these meetings as a very important opportunity to connect and communicate with the parents.

Some of the final recommendations from the teachers included having smaller class sizes for those schools with large ESOL populations. Teachers should also take language classes in order to communicate more effectively with the students and parents. Finally, cultural diversity training should be offered to the teachers in order to avoid prejudices and lower expectations from the teachers when working with ELLs. 


\section{Beaufort County ELLs and Critical Theory}

The situation of the Beaufort County school system and the remarkable success it has made with its ESOL student population make this school system worthy of study to analyze what went right over the course of the past few years. Contrary to what the past and current trends would predict to happen to this group of students, the ESOL students of Beaufort County have overcome many obstacles to obtain success in the schools. These students arrived as outsiders to a place where they did not speak the native language or belong to the dominant culture. This situation had all of the characteristics necessary and the potential for these students to become marginalized and ignored in schools. This has been the case in many school systems that are plagued by mass failure and drop-out rates among ESOL students; however, the ESOL student population of Beaufort County has posted award winning gains on standardized tests.

\section{Critical Literacy and Critical Pedagogy}

In the case of Beaufort County ESOL students, learning a new language was the barrier they confronted. They had to learn a new language in order to fare well on the standardized tests that are the measures of 'success' in schools. Freire noted that language was a tool of oppression used to, "reproduce dominant forms of power relationships" (MacLauren and Leonard, 1993, p. 53). Giroux (1993) stated that schools must start thinking differently about language and literacy so that Others are no longer, "excluded within the dominant discourse of schooling” (p.367). Kincheloe (2008) stated that Others can be emancipated and liberated through education when, “pedagogy believe that nothing is impossible when we work in solidarity with love, respect, and justice as our guiding lights” (p. 9). He continued to say that when this happens, the end result will be, 
“empowerment to all students" (p. 9). Kincheloe (2008) continued to say that "if enough people think in new ways, social and pedagogical transformation is inevitable” (p. 32). In Beaufort County, the transformation began with the right person—Sarah Owen—thinking in the right way. Fortunately for the ESOL students of Beaufort County, she also taught other teachers to think in new ways via SIOP training.

Despite the many obstacles the ESOL students confronted, they did not fall victim to cycle of oppression outlined by the critical theorists. This group of students has found success.

From the interviews conducted with Sarah Owen, the ESOL teachers, and the mainstream teachers, all of the aforementioned people must share the credit for this accomplishment. Sarah Owen receives credit for bringing her experience as an ESOL teacher in the classroom and transitioning that experience into her new role as the ESOL Coordinator for the county. Her focus on teacher training has had a trickle-down effect throughout the entire county that has resulted in ESOL student success. The ESOL teachers have been the "go-to" contact people in the schools for providing teacher training and support for accommodating this group of students. They have also been instrumental for getting the parents involved and participating in the students' education through the ESOL Parent Nights in the schools. Last but not least, the mainstream teachers are the responsible for imparting the majority of the ESOL students' education in Beaufort County Schools. This group of teachers has not only been responsible for content-area instruction, but they have also been simultaneously transformed into language instructors as well, a role which most were happy to accept once they had the proper training. According to Kincheloe (2008), the purpose and goal of critical pedagogy is "to help educators and teachers 
reconstruct their work so it facilitates the empowerment of all students” (p. 9). For the mainstream teachers of Beaufort County, their work was reconstructed through the process of learning the SIOP model and other ESOL strategies, approaches, and accommodations.

Based on the levels of success as measured by standardized test scores in Beaufort County, it seems that Sarah Owen, the ESOL teachers, and the mainstream teachers have worked cooperatively with "love, respect, and justice" to achieve the "empowerment of all students” of which Kincheloe spoke (2008, p. 9). This ability to perform as well or better than the native speakers on standardized tests has proven that the ESOL students in Beaufort County are "no longer excluded from the dominant discourse of schooling” (Giroux, 1993, p. 367). Furthermore, lack of language skills can no longer be used as what Freire calls a tool of oppression "to reproduce dominant form of power relationships” because the ESOL students of Beaufort County have mastered this tool as far as standardized tests are concerned (MacLauren and Leonard, 1993, p. 53).

\section{Implications Based on Emerging Themes}

There were several implications on accommodating a large ESOL student population that evolved from the findings of this research study. While the focus of the study was ESL policy, leadership, and teacher training, several important subthemes emerged from the teacher interviews. The implications are arranged as they relate to the main components of the conceptual framework.

\section{ESL Policy and Leadership}

The first implication is that school systems should not rely on one uniform type of ESOL instruction for an entire school system. The ESOL method chosen should be based 
on the needs of the school as dictated by the size of the ESOL population. Additionally, the district ESOL coordinator should offer ESOL training on-site for teachers without ESOL experience.

\section{Teacher Training}

The second implication of this study is that additional teacher training such as SIOP should be required for all mainstream teachers working with ELLs. This training will serve a double purpose as it benefits both ELLs and native English speakers. The third implication of this study is that the person conducting a training session should be a high-quality trainer. The quality of the person giving the training can determine whether or not a training workshop is successful and beneficial to teachers. The fourth implication from this study is that ESOL teacher training and professional development should be ongoing throughout the school year. Additionally, it should be offered at times that are convenient to the teachers. The fifth implication is that teacher training and teacher attitude are correlative. Several of the teachers reported having improved attitudes once they had completed the SIOP training and felt adequately prepared to work with ESOL students. Those that did not use the SIOP accommodations and did not see good student achievements experienced more frustrations and negative attitudes. The sixth implication is that workshops on cultural awareness and cultural differences should be offered to the teachers to prevent cultural stereotypes and prejudices. The seventh implication related to teacher training is that teachers must arrive to the point that they feel comfortable working with the ESOL students. Several of the teachers spoke about the benefits of the SIOP training helping them to feel comfortable and prepared to work with the ESOL students. Additionally, the teachers reported better attitudes towards the students once 
they obtained being 'comfortable' working with the ELLs. The eighth implication for this study is that there is a difference between earning an ESOL endorsement on paper and in practice. Although a couple of the teachers earned the ESOL endorsement after the ESOL population boom in Beaufort County, they reported that were still not sure what to do the training they had received. These responses indicate that there is a disconnect between taking the additional courses to obtain an ESOL endorsement and putting the knowledge gained from those courses into practice. The final implication from this study is the based on the importance of language and the ability to communicate. School systems should offer more than basic language classes to the teachers so that they have the ability to communicate with the lower-level students and their parents.

\section{Recommendations and Model for other school systems}

Based on the results of the teacher interviews and the ESOL student success obtained in Beaufort County schools, the following recommendations were compiled for other school systems trying to successfully accommodate a large ESOL student population. The ESOL district coordinator should be a highly-qualified ESOL teacher. This allows the coordinator to bring their teaching experience and expertise to the school system. Secondly, the coordinator should provide quality training to non-ESOL teachers via workshops given by the coordinator or outside consulting firms. Secondly, the role of the ESOL teachers in a school need to transition. Rather than focusing exclusively on educating the students, ESOL teachers need to be utilized to provide immediate on-site training for mainstream teachers. They should also work collaboratively with mainstream teachers to provide extra help, support, or intervention as needed by the students. Next, ESOL teachers should be utilized to teach content-area course for which they are 
qualified until mainstream teachers are properly trained to work with ELLs. Finally, ESOL teachers should work collaboratively with mainstream teachers to compile reference guides with sample lesson plans teachers in each subject area and each grade level. This would serve not only as a quick reference guide when the teachers have questions, but it would also model how lessons can be tailored with the ESOL accommodations. The final recommendation for other school systems is to invest and foster outside support for ESOL students. These types of supports include computer labs to help with language learning, language classes to help improve communication with lower-level students and all ESOL parents, and extra tutoring outside of school if needed. The results of the interviews with the ESOL and mainstream teachers, the following a top-down model was created based on Beaufort County's process to ensure ESOL student success in mainstream classes. It is my hope that other school systems can follow this model and the recommendations from the Beaufort County teachers in order to successfully accommodate ESOL students in their school system. (See Figure 13). 
Figure 13. Model for Beaufort County’s success

\section{Establish ESOL policies and provide district-wide teacher support.}

Arrange for outside firms to offer various forms of teacher and administrator training.

\section{ESOL Teachers}

Provide on-site teacher training and support.Shift concentration from only teaching language and more focus on intervention. Teach content area classes until all teachers are adequately trained to teach ESOL students.

\section{Mainstream teachers}

Instruct ESOL students on content and langauge skills. Collaborate with ESOL teachers
Utilize the ESOL training provided by the district and in-school ESOL teachers.

Areas for Future Research

As previously stated, the ESOL students of Beaufort County have been very successful in U.S. schools and broken the trends that many other ESOL students are experiencing. For future research, I would like to compare the steps taken by the Beaufort County school system to those taken by other school systems that have been successful in accommodating ESOL students, such as Springdale, Arkansas. While the Beaufort County schools system has worked primarily with Spanish speakers, the majority of the Springdale, Arkansas school district's ESOL population comes from the Marshall Islands and Spanish-speaking countries. I would be very interested to see if these two districts share common methodologies and approaches with their ESOL students. This type of study would allow for some cross-comparison to see if teaching 
training or different teaching methodologies have a greater influence on ESOL student success.

As a continued research project with the Beaufort County school system, I would also like to interview the some of ESOL students and their parents. I would like to gain their input on why they have been successful. This could add another important dimension to this study based on the parents' and students' points of view. Researcher's Point of View

When I first learned of the very large ESOL population in Beaufort County and started thinking about the selection of this school system for my research study, I expected to tell a very different story. This was not an area or school system used to having large numbers of ESOL students. I originally thought the study would be an attitudinal study on the teachers and how they felt about having a large population of ESOL students that arrived suddenly in the area. I predicted that the story of Beaufort County's ELLs would mirror what is happening in many schools in the U.S. with large student failure rates, negative teacher attitudes, high dropout rates, and large numbers of non-English speakers existing or flying under the radar in schools, but not thriving. It was through conducting the literature review and my conversations with Sarah Owen that I learned about the success of the ESOL students. As a result, I am much happier to tell the story of ESOL students' success rather than failure in the Beaufort County schools. I sincerely admire and respect Sarah Owen, the ESOL-lead teachers, and the mainstream teachers for the job they have done with the ESOL population in their schools. However, the story of the ELLs and teachers of Beaufort County has political ramifications for other schools systems with a large number of ESOL students. They have proven that it is 
possible for a recently arrived immigrant population to assimilate and to be successful in U.S. schools. Therefore, it raises the question of why these same results have not been replicated in other schools systems. Are these mass failures occurring due to lack of teacher training, lack of effective leadership, lack of resources, negative teacher attitude, lack of ESOL and mainstream collaboration or something more?

As a critical theorist, these massive failure rates among ESOL student populations in the U.S. equate to a lack of social justice. My job, as well of that of my fellow educators, is to ensure that students leave my classroom adequately prepared with the skills they will need in future, regardless of the amount of English they speak. If they don't, they are doomed to repeat cycles of oppression, domination, and often, poverty. I do not intend to imply that for immigrant families learning to speak English is a golden ticket for success in this country. However, I do intend to say that having the language skills necessary to succeed in schools does offers the opportunity to obtain success through hard work and study. In other words, achievement in school and learning English offers access to success for these students. The access to and the possibility of success offers these children and their future generations the chance to escape marginalization and to break the cycle of oppression.

While the success story of Beaufort County's ELL students and a positivist researcher stance may seem contradictory to critical theory, critical theory does offer tools for liberation from oppression. I chose to focus on liberation and how it can be achieved in other schools. In my opinion, Kincheloe (2008) hit the nail of the head when he said "if enough people think in new ways, social and pedagogical transformation is inevitable” (p. 32). More school leaders need to approach ESOL programs in new ways. 
The data shows that what we have been doing in the past is not working. It is time to try something new. Critical pedagogy and critical literacy are essential in changing schools’ approach to ESOL students and in liberating students from repeating cycles of oppression. This type of transformative change does not happen in isolation. It requires the cooperative efforts of school leadership, teachers, students, and the parents. Sarah Owen summarized her approach to making change in the schools by saying,

schools need to focus on the mainstream teachers since that is where students spend the majority of their time. The next key is also getting the parents involved. If schools can do that, it will transfer into student achievement.

With this quote, Ms. Owen has given other schools her secret to liberation. Schools need to focus their energy and resources more on the mainstream teachers and what they need in order to successfully accommodate ESOL students into their classes. Second, schools need to focus on strengthening the support system that students have outside of schoolthe parents. Ms. Owen, the ESOL teachers, and the teachers of Beaufort County have proven that if these new approaches are taken, ESOL students will find success in U.S. classrooms. 


\section{REFERENCES}

A Nation At Risk: The Imperative for Educational Reform (1983). Washington, D.C.: The Commission on Excellence in Education.

About Pisa (2012). Retrieved April 14, 2014 from http://www.oecd.org/pisa/aboutpisa/.

Alvarez, C. M. and Fernandez, S. E. (2000). Ethnic Identity Understanding Contemporary Perspectives. Needham Heights, MA: Pearson.

Applied Research Center (2012). American Educational History. Retrieved April 23, 2013 from http://www.eds-resources.com/educationhistorytimeline.html.

Beaufort County Council Approves Immigration Proposal (2006, December 27). The Associated Press. Retrieved March 25, 2014 fromhttp://m.savannahnow.com/associated-press/2006-12-27/beaufort-county-council-approves-immigrationproposal.

Beaufort County schools could be guide for others. (2010, September 1). Island Packet. Retrieved May 3, 2011 from http:/www.islandpacket.com/2010/09/01/1356205/beaufort-county-schoolscould.html.

Beaufort schools recognized by state. (2005, June 11). Island Packet. Retrieved May 3, 2011 from http:/www.islandpacket.com/2005/06/11/350459/beaufort-schoolrecognized-by.html.

Bidwell, A. (2014). The History of Common Core State Standards. U.S. News and World Report. Retrieved March 23, 2014 from http://www.usnews.com/news/specialreports/articles/2014/02/27/the-history-of-common-core-state-standards.

Bourdieu, P. (1984). Distinction: A social critique of the judgment of taste. Cambridge,MA: Harvard University Press.

Brownstein, D. (2008, July 13). Beaufort County Begins Crackdown on Illegal Immigrants. Island Packet. Retrieved March 25, 2014 from http://www.islandpacket.com/2008/07/13/548926/beaufort-county-beginscrackdown.html.

Bryan, C. (2010, February 18). Reality of Race: South Carolina has nation's fastest growing Latino population. News 2. Retrieved from 
http://www2.counton2.com/news/2010/feb/18/reality_of_race_south_carolina_has _nations_fastest-ar-535087/.

California Department of Education (2012). Adequate Yearly Progress (AYP). Retrieved February 5, 2013 from http://www.cde.ca.gov/ta/ac/ay/.I

Case Briefs (2013). Plyler vs. Doe. Retrieved August 8, 2013 from

http://www.casebriefs.com/blog/law/constitutional-law/constitutional-law-keyedto-cohen/the-equal-protection-clause-and-the-review-of-the-reasonableness-oflegislation/plyler-v-doe-2/.

Census Tract in Beaufort County, South Carolina Income and Careers. (2013). Retrieved January 14, 2013 from http://www.usa.com/SC013000902-income-andcareers.html.

Center for Applied Linguistics (2014). What is SIOP? Retrieved April 25, 2014 from http://www.cal.org/siop/about.

Cerve, K. (2011, January 31). Beaufort County schools set a record for Palmetto Gold, Silver Awards. Beaufort Gazette. Retrieved May 3, 2011 from http://www.lowcountrynewspapers.net/archive/2011/01/31/story/beaufort-countyschools-set-record-palmetto-gold-silver-awards.

Coleman, J. (1966). The Equality of Educational Opportunity Study (EEOS). Retrieved August 6, 2013 from http://www.icpsr.umich.edu/icpsrweb/ICPSR/studies/06389.

Cummins, J. (1996). Negotiating identities: Education empowerment in a diverse society. Los Angeles, CA: California Association of Bilingual Education.

Curtin, E. (2005, Spring). Teaching Practices for ESL students. Multicultural Education, 12(3), 22-27. Retrieved July 25, 2007 from http://www.eric.ed.gov/PDFS/EJ711231.pdf

Denzin, N. K. (1978). The research act: Atheoretical introduction to sociological methods (2nd ed.). New York: McGraw-Hill.

Department of Education (2001). Definition of LEP. Retrieved February 5, 2013 from http://www.doe.virginia.gov/federal_programs/esea/title3/part_a/definitions/limite d_english_proficient.pdf

Dungca, N. (2012, October 3). Portland Public Schools administrator calls data on ESL student progress 'unacceptable'. The Oregonian. Retrieved from 
http://www.oregonlive.com/portland/index.ssf/2012/10/portland_public_schools_ admini_1.html on January 28, 2013.

Editorial Projects in Education (2004, August 3 and 2011, July 18). Adequate Yearly Progress. Education Week [Electronic Copy]. Retrieved February 18, 2013 from http://www.edweek.org/ew/issues/adequate-yearly-progress/.

Erzerberger, C., \& Prein, G. (1997). Triangulation: Validity and empirically based hypothesis construction. Quality and Quantity, 31, 141-154.

Farmer, T., Robinson, K., Elliot, S.J., \& Eyles, J. (2008). Developing and Implementing a Triangulation Protocol for Qualitative Health Research. Qualitative Health Research [Electronic Copy], 16, 377-396. Retrieved June 21, 2014 from http://qhr.sagepub.com/cgi/content/abstract/16/3/377.

Florida Department of Education (2013). Consent Decree. Retrieved April 2, 2013 from http://www.fldoe.org/aala/cdpage2.asp.

Freire, P. (1970). Pedagogy of the oppressed. New York: Continuum.

Gall, M., Gall, J., \& Borg, W.(2003). Educational Research ( $7^{\text {th }}$ ed.). Boston: A \& B.

Garcia, E. E. (1992). The Education of linguistically and culturally diverse students: Effective instructional practices. Washington, D.C.: Center for Applied Linguistics.

Giroux, H. (2006). America On The Edge. USA: Macmillan.

Giroux, H. (1993). Literacy and the politics of difference. In Critical Literacy politics, praxis, and the postmodern. Lankshear, C. and McLaren, P. (Eds.). New York: State University of New York Press.

Gray, L. (2008, May 1). S.C. has fastest growing Hispanic population in the nation. Go Upstate. Retrieved November 23, 2008 from http://www.goupstate.com/article/20080501/NEWS/932308682

Hatfield, M. M., Edwards, N. \& Bitter, G. (1997). Mathematics methods for elementary and middle school teachers ( $3^{\text {rd }}$ ed.). Boston: Allyn \& Bacon.

Henry, T. (2002, April 25). Hispanic schools hurting for teachers. USA Today. Retrieved on December 5, 2006 from 
http://www.usatoday.com/educate/college/education/casestudies/20010831educ01.pdf

Hilton Head Elementary sees increase in Hispanic students. (2001, August 10). Island Packet. Retrieved May 3, 2011 from http:/www.islandpacket.com/2001/08/10/327775/Hilton-head-elementary-seesincrease.html

Hispanics are now the largest minority group in the United States. (2010, September 10). South Carolina Hispanic Outreach-Acercamiento Hispano de Carolina del Sur. Retrieved July 23, 2011 from www.schispanicoutreach.org/us.html

Horwitz, A. R., Uro, G., Price-Baugh, R., Simon, C., Uzzell, R., Lewis, S., Casserly, M.,(2009 October). Succeeding With English Language Learners: Lessons Learned from the Great City Schools. Retrieved September 10, 2011 from http://www.cgcs.org/publications/ELL_Report09.pdf

Jones, A. (2010, June 11). Hispanic population soars in county. Tuscaloosa News. Retrieved July 27, 2011 from http://www.tuscaloosanews.com/article/20100611/NEWS/100619973

Kincheloe, J.L. (2008). Knowledge and Critical Pedagogy. USA: Springer.

Kincheloe, J. L., \& McLaren, P. (2000). Rethinking critical theory and qualitative research. In N. Denzin \& Y. Lincoln (Eds.), Handbook of qualitative research (pp. 279-314). Thousand Oaks, CA: Sage.

Knight, E.W. (1922). Public Education in the South [Electronic Version]. Boston, MA: The Athenaeun Press. Retrieved February 18, 2013 from http://books.google.com/books?id=P4sWAAAAIAAJ\&printsec=frontcover\#v=on epage \&q\&f=false.

Kuehn, B. (2001, August 13). Schools reflect Hispanic migration. Island Packet. Retrieved May 3, 2011 from http:/www.islandpacket.com/2001/08/13/334891/schools-reflect-hispanicmigration.html.

Lincoln, Y. S., \& Guba, E. G. (1985). Naturalistic inquiry. Beverly Hills, CA: Sage.

Lopez, J. (2008, September 29). ELL/ESL/LED/Bilingual Education Has Failed Students. Opposing Views, Fall 2008. Retrieved January 30, 2013 from 
http://www.opposingviews.com/arguments/ell-esl-led-bilingual-education-hasfailed-students.

Lucas, T., Henze, R., Donato, R., (1990). Promoting the Success of Latino LanguageMinority Students: An Exploratory Study of Six High Schools [Electronic Version]. Harvard Educational Review, 6(3). Retrieved on January 27, 2013 from http://her.hepg.org/content/0160105tt9kgkq51/.

Marshall, C. \& Rossman, G. (1999). Designing Qualitative Research ( $3^{\text {rd }}$ Ed.). Thousand Oaks, CA: Sage.

Maxwell, L.A. (2009). Shifting Landscape: Immigration Transforms Communities [Electronic Version]. Education Week, 28 (17). Retrieved on June 16, 2009 from www.edweek.org/go/qc09

Maxwell, J. (1996). Qualitative Research Design: An interactive approach. Thousand Oaks, CA: Sage.

Murray, D.E. (2009). A Model for Leadership in English Language Teaching: An Introduction to Leadership IQ. In Christinson, M. \& Murray, D.E. (Eds.), Leadership for English Language (27-49). New York: Taylor \& Francis.

No Child Left Behind (2002). No Child Left Behind: Elementary and Secondary Education Act. Retrieved on March 23, 2014 from www.ed.gov/nclb.

Opala, J. The Gullah: Rice, Slavery, and the Sierra Leone-American Connection. Retrieved March 23, 2012 from http://yale.edu/glc/gullah/index.htm.

Payán, R. and Nettles, M. Current State of English Language-Learners in the U.S. K-12 Student Population. Retrieved February 6, 2013 from http://www.ets.org/Media/Conferences_and_Events/pdf/ELLsympsium/ELL_fact sheet.pdf.

Peterson, Larry (2011, March 19). Hispanics pace population growth in Savannah as whites and blacks trickle away. Savannah Now. Retrieved March 24, 2013 from www.savannahnow.com/savannah-whites-and-blacks-trickle-away.html.

Portes, A. (1981). Modes of incorporation and theories of labor migration. In M.K. Kirtz, C.B. Keely, \& S. M. Tomasi (Eds.) (pp. 279-297), Global Trends on Global Migration: Theory and Research on International Populations. New York, NY: Center for Migration Studies. 
Portes, A. \& Bach, R.I. (1985). Latin Journey: Cuban and Mexican Immigrants in the United States. Berkley, CA: University of California Press.

Park, R.E. (1950). Race and Culture. New York, NY: The Free Press.

Pew Hispanic Center. (2010). Demographic Profile of Hispanics in South Carolina. Retrieved April 14, 2010 from http://pewhispanic.org/states/?stateid=SC

Presmeg, N. C. (1989). Visualization in multicultural mathematics classrooms. Focus on Learning Problems in Mathematics, 11(91), 17-24.

Program for International Student Assessment (2012). Retrieved April 15, 2014 from http://nces.ed.gov/surveys/pisa/.

Scherer, M. (n.d.). A Summary of A Nation At Risk: The Imperative for Educational Reform, 1983. Retrieved April 15, 2014 from https://www3.nd.edu/ rbarger/www7/nationrs.html.

Smith, P.C. (2004, Spring). Pre-service teachers' attitudes regarding ESL students. Academic Exchange Quarterly, 8(1), 183-187.

Smith-Adcock, S., Daniels, M. H., San Lee, J. A. V., \& Arce Indelicato, N. (2006, October). Culturally responsive school counseling for Hispanic/Latino students and families and need for bilingual school counselors. Professional School Counseling, 10(1), 92-102. Retrieved December 5, 2006 from http://libres.uncg.edu/ir/uncg/f/J_Villalba_Culturally_2006.pdf

South Carolina Approves Revoking Licenses To Businesses that Hire Illegals (2006, December 28). Fox News. Retrieved March 24, 2014 from http://www.foxnews.com/story/2006/12/28/south-carolina-county-approvesrevoking-licenses-to-businesses-that-hire/.

South Carolina Department of Education (2011). English Language Learning Handbook [Electronic Copy]. Retrieved August 7, 2013 from http://ed.sc.gov/agency/programs-services/90/documents/ELLHandbook.pdf.

South Carolina Schools Annual Report Card (2012). Retrieved May 13, 2013 from http://ed.sc.gov/data/report-cards/2012/district/s/d0701999.pdf.

Staff Reports (2005, June 11). Beaufort school recognized by state. Island Packet. Retrieved May 3, 2011 from http://www.islandpacket.com/2005/06/11/350459/beaufort-school-recognizedby.html 
Staff Reports (2010, September 1). Beaufort County schools could be a guide for others. Island Packet. Retrieved May 3, 2011 from http://www.islandpacket.com/2010/09/01/1356205/beaufort-county-schoolscould.html

Tadeu da Silva, T. and McLaren, P. (2003). Decentering Pedagogy: Critical Literacy, Resistance and the Politics of Memory. In McLaren, P. and Leonard,P. (Eds.), PAULO FREIRE A Critical Encounter. New York: Chapman and Hall.

The Associated General Contractors of America. Overview: Hispanics in South Carolina. (2007). Retrieved November 26, 2007 from http://www.cagc.org/spanish_res/hisp_sc.cfm

The University of South Carolina Consortium for Latino Immigration Studies (2008, October 13). Latinos in South Carolina-Fast Facts. Retrieved September 10, 2011 from http://www.sph.sc.edu/cli/SCdatafacts.htm.

The U.S. Census Bureau. (2000). Selected Appendixes: Summary Social, Housing, Economic Characteristics. Retrieved on March 23, 2012 from http://www.census.gov/population/cen2000/phc-2-a-B.pdf.

The U.S. Census Bureau. (2009, August 28). By the numbers: Meet Hispanic America. Retrieved on June 23, 2010 from http://www.erietvnews.com/story/7031311/bythe-numbers-meet-hispanic-america

The U.S. Department of Education (2001). No Child Left Behind Act. Retrieved June 14, 2010 from http://www2.ed.gov/policy/elsec/leg/esea02/index.html.

Tornoe, J. (2004). South Carolina's Hispanic Population Researched by USC. Retrieved November 26, 2007 from http://juantornoe.blogs.com/hispanictrending/2004/06/south_carolinas.html

Truesdale, V. (2010, February 15). English as a second language classes a growing need. Island Packet. Retrieved May 3, 2011 from http:/www.islandpacket.com/2010/02/15/1138988/Valerie-truesdale-english-asa.html

Tuscaloosa City Schools (2011). Proposed System Reforms. Retrieved February 5, 2013 from http://www.tusc.k12.al.us/proposed-system-reforms/.

United States Census Bureau (2007). Hispanics in the United States (Publication No. CB07-FF.14). Send via e-mail from Anglea C. Baker on September 6, 2007. 
Usher, Alexandra (2012). AYP for 2010-11. Center on Educational Policy. Retrieved on February 18, 2013 from http://www.cepdc.org/displayDocument.cfm?DocumentID=414.

What is PISA and Why Does it Matter? (2014). Retrieved April 10, 2014 from http://asiasociety.org/education/learning-world/what-pisa-and-why-does-it-matter.

Willis, J.W. (2007). Foundations of Qualitative Research: Interpretive and Critical Approaches. Thousand Oaks, CA: Sage.

Yin, R. (1984). Case Study Research: Design and Methods. Beverly Hills, CA: Sage.

Young, R.D. (2005). The Growing Hispanic Population in South Carolina: Trends and Issues. Retrieved January 3, 2007 from http://www.ipspr.sc.edu/publication/Population\%20In\%20SC.pdf

Wright, S. (2011, January 8). Students learn English at race pace. Bluffton Today. Retrieved January 10, 2011 from http://www.npaper-wehaa.com/blufftontoday/2011/01/09/s1/\#?article=1134256.

Zehr, M. (2006, October 11). Limited Number of Schools Absorb Latinos. Education Week, (26) 7, 5-14. Retrieved on December 5, 2006 from http://www.edweek.org/ew/articles/2006/10/11/07hispanic.h26.html 
Appendix A 


\section{BEAUFORT COUNTY SCHOOL DISTRICT I-42 Form 5 Application Request for Research Project}

\section{Instructions}

Researcher: Please type or print using black ink. This form must be forwarded to school district officials to grant approval for conducting research in the BCSD. Note that any research conducted may not place an undue burden on district employee time or assigned tasks. At no time may the instructional program be interrupted or changed in order to accomrnodate the research.

University/Organization: Please provide all documentation endorsing this request.

\section{Researcher's Personal Information}

First Name: Amanda. Middle: Gâil_Last Name: de Varona

Maiden : McCready Social Socurity/Employee \# C08-65-6.

Address: University of Miami-Aller 305

City: Coral Gables State: FL. Zip Code 33178 Cell \#786-376-452

Eumail: a.agil

IF YOU ARE A BEAUFORT COUNTY EMPLOYEE YOU MAY SKIP TO SECTION III BELOW. SECTION II

Required for SLED check: Birth date:_9_/24 / 1977_ $\quad$ M F

Have you ever begen convicted of a felony, misdemenanor, or a crime involving moral turpltude (including but not limited to theft, attempted theft, rape, murder swinding, shop lifting, sele or possesslon of an illegal drug, assaut and indecency with a minor) and/or recelved probation or deferred adjudication?

D Yes 12 No If yes, please explain. If more space is needed, attach an additional sheet.

My signature below certifles that I understand that If I misrepresent or omit any information as requested on this application and/or during the application process, such misconduct is cause for forfeiture of consideration and/or dismissal. I herewith authorize Beaufort County School District to request and receive confidential release of documentary materials relating to me, regardless of physical form or characteristics, prepared, owned, used, in the possession of, or retained by (1) educational institutions I have attended (2) previous employers of mine and (3) city, county, state and federal law enforcement authorities. Convietion of a felony is not an automatic bar. The district will consider the nature, date, and relationship between the offense and the position for which the candidate applies. If you are not sure If your police problerm fits the above definition, you are encouraged to inform the school district of your problery.

Amanda de Vorono

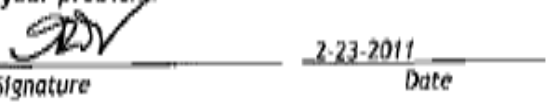

Printed Name

SIgnature Date 
SECTION III.

PURPOSE OF RESEARCH: Doctoral Disstertation

Other(what)

BRIEFLY DESCRIBE THE RESEARCH PROJECT YOU ARE CONDUCTING AND WHAT ACCESSINFFORMATION YOU NEED IN ORDER TO PROCEED.

I am researching school systems that hove confronted the issue of rapidly accommodating a large ESL student

I am researching school systems that have canl in the BCSD to gain their perspective and advice on how other
population. I would like to interview 4 teachers in
sthool districts confronting the same issue can do so successfully.

EXPLAIN HOW THE DATA YOU WILL COLLECT WILL BE USED AND DISSEMINATED.

The data will be collected through telephone interviews scheduled at the teachers' convenience.

Any data collected will be used only for the purposes of completing my doctoral dissertation. 


\section{Section IV.}

\section{CONFIDENTIALITY AGREEMENT}

My signature below certfies that I understand that while I am working as a researcher and am under the supervision of a Beoufori County School District employee, I may have access to records and files that contain confidential information. Furthermore, I understand that it is che employer's obligation to protect the rights of these flies ond/or individuals and that I will follow the operating proctices and procedures required while handling these records. I agree that I will not inappropilately access or disclase this information. Furthermore, I acknowledge that if I violate this agreement, then I have jeopardized the continuance of my association with Beaufort County School District.

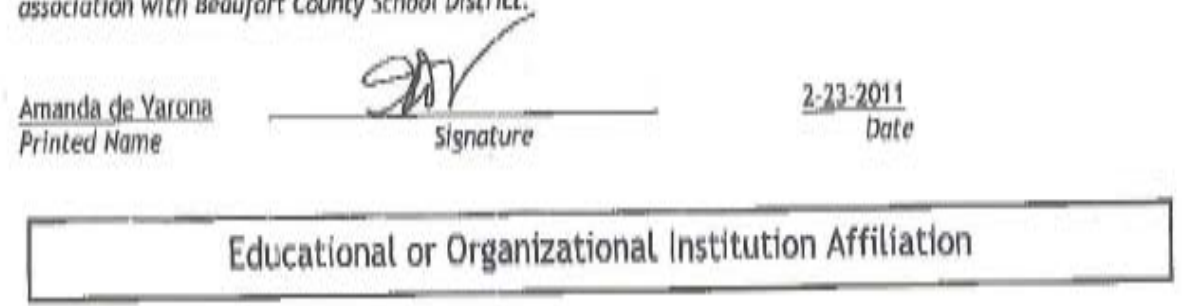

\section{SECTION V.}

If the research you are conducting is for a University degrec program or for a specific agency or organization, please complete:

University/Organization Name: Florida International University

Address: UP Campus.2 2 nil, Florida 33199

Name of Supervisor: Dr. Eric Dwyer

Supervisor's Contact Address and Phone Number: Same address as above 305-348-20

Please place this form in the district courier addressed to: Chief instructional Services Officor, Instructional Services Dept. IMink Point.

OR

Mail this completed form to:

Chief Instructional Services Officer

Beaufort County Schools

Po Drawer 309

Beaufort, SC 2990'1

The office will respond to your request as soon as possible.

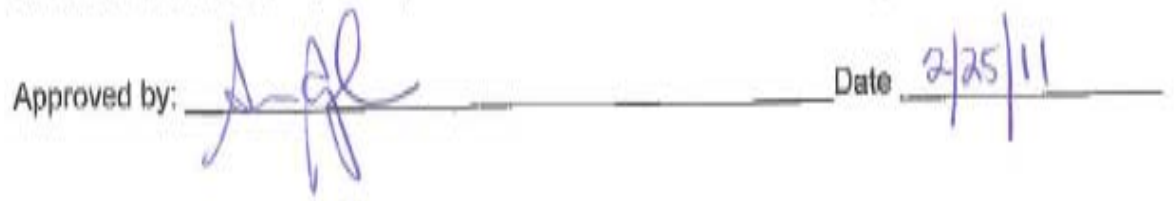




\begin{abstract}
APPENDIX B
This is the form requesting your participation in a graduate research project I am conducting through Florida International University in Miami, Florida. The purpose of this research project is to get feedback from the teachers of Beaufort County, South Carolina about the rapid changes schools have experienced in the number ESOL students. You are invited to participate in this research project because you have taught in Beaufort County schools during the time these changes in student population were taking place.
\end{abstract}

Your participation in this research study is completely voluntary. You may choose not to participate. If you decide to participate in this research survey, you may withdraw at any time. If you decide not to participate in this study or if you withdraw from participating at any time, you will not be penalized.

The procedure involves completing an interview via phone or e-mail that will take approximately 30 minutes. Your responses will be confidential and we do not collect identifying information such as your name, email address or IP address. The survey questions will be about your experiences with the rapidly changing ESL population in Beaufort County and your recommendations for other schools.

I will keep your information completely confidential. All data is stored in a password protected electronic format. To help protect your confidentiality, the surveys will not contain information that will personally identify you. The results of this study will be used for scholarly purposes only and may be shared with Florida International University representatives.

If you have any questions about the research study please contact me, Amanda de Varona at a.XXX@miami.edu or 786-XXX-XXX or Eric Dwyer, Supervising Professor, at 305XXX-XXXX or eXXXXX@fiu.edu. This research has been reviewed and approved according to Florida International University IRB procedures for research involving human subjects.

ELECTRONIC CONSENT: Please select your choice below.

Clicking on the "agree" button below indicates that:

- you have ready the above information

- you voluntarily agree to participate

- you are at least 18 years of age

If you do not wish to participate in the research study, please decline participation by clicking on the "disagree" button. 
VITA

AMANDA GAIL DE VARONA

Born, Savannah, Georgia

1995-1998

B.A., Spanish

Georgia Southern University

Statesboro, Georgia

1999-2002

M.A., Spanish

Florida International University

Miami, Florida

2002-2014

Doctoral Candidate

Florida International University

Miami, Florida

$1999-2002$

Graduate Teaching Assistant

Florida International University

Miami, Florida

2002-2005

Miami-Dade College

EAP Lecturer

Miami, Florida

2005-2008

University of South Carolina

Spanish Instructor

Bluffton, South Carolina

2009-2014

University of Miami

Intensive English Program Lecturer

Miami, Florida

\section{PRESENTATIONS}

de Varona, A. G., (May 2004). Short, Sweet, and Simple: Peer Editing and Correcting. Presentation at Sunshine State TESOL Tampa, Florida.

de Varona, A. G., (September 2005). “The Wayúu Tayá Culture of Sinamaica, Venezuela”. Presentation for University of South Carolina's International Week Beaufort, South Carolina. 
de Varona, A. G., (January 2006). WHO will be reading my essay? Presentation for 4th Annual Hawaiian Conference on Languages, Literature, and Education Honolulu, Hawaii.

de Varona, A. G., (January 2007). Hot Topics in the Language Classroom. Presentation for 5th Annual Hawaiian Conference on Languages, Literature, and Education Honolulu, Hawaii.

de Varona, A. G., (March 2008). The Times and Trials of the Women of La línea del sol Presentation for 7th International Congress on Hispanic Literature Cusco, Peru.

de Varona, A. G., McGrath-Moreira, K., Kramer, D. \& Giles, L. (March 2012). Debate: A Bridge Activity from IEP to University Classrooms. Presentation for TESOL National Convention Philadelphia, Pennsylvania. 